Дальневосточный федеральный университет Восточный Институт - Школа региональных и международных исследований

\author{
Ю.А. Ишутина
}

\title{
КИТАЙСКИЙ ОПЫТ НРАВСТВЕННОГО ВОСПИТАНИЯ: ВОСХОЖДЕНИЕ К ИДЕАЛУ
}

Монография

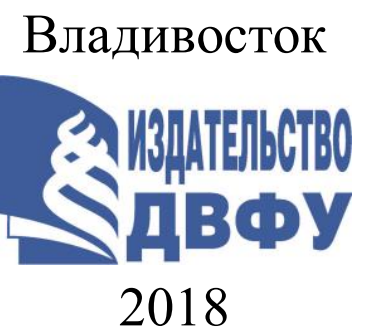


Автор Юлия Александровна Ишутина - заведующая кафедрой китаеведения ВИ - ШРМИ ДВФУ, кандидат культурологии, стажировалась в Харбинском политехническом университете, Хэйлунцзянском университете, Шанхайском университете Саньда, опубликовала более 40 печатных работ.

\section{Рецензенты:}

Г.В. Алексеева, доктор искусствоведения, профессор

Департамента искусств и дизайна Школы искусств и гуманитарных наук Дальневосточного федерального университета; Н.А. Коноплева, д-р культурологии, доцент, профессор кафедры дизайна и технологий Владивостокского государственного университета экономики и сервиса.

\section{Ишутина, Юлия Александровна.}

И97 Китайский опыт нравственного воспитания: восхождение к идеалу : монография / Ю.А. Ишутина; Дальневосточный федеральный университет, Восточный Институт - Школа региональных и международных исследований. - Владивосток : Изд-во Дальневост. федерал. ун-та, 2018. - 110 с.

ISBN 978-5-7444-4435-8.

DOI dx.doi.org/10.24866/7444-4435-8.

В монографии исследуются вопросы формирования нравственных идеалов в современном Китае. Конфуцианские ценности, составляющие основу китайской культуры, усваиваются китайской молодежью на уровне повседневности, но высокие идеалы древности утрачивают свою притягательность и актуальность для людей, живущих в качественно ином информационном пространстве. В настоящее время в КНР происходят процессы героизации личности на жизненных примерах бойцов НОАК начала строительства Нового Китая. Таким является образ Лэй Фэна, не совершавшего значительных подвигов, но оставившего о себе добрую память благодаря поступкам в духе конфуцианских категорий.

The monograph examines the formation of moral ideals in modern China. Confucian values, which form the basis of Chinese culture, are assimilated by Chinese youth at the level of everyday life, but the high ideals of antiquity lose their attraction and relevance for people living in a qualitatively different information space. Currently, in the People's Republic of China, the processes of heroization of the individual are taking place on the basis of the life examples of PLAC soldiers of New China. Such is the image of Lei Feng, who was not a hero, but left a good memory of himself due to actions in the spirit of Confucian categories. 


\section{Оглавление}

ВВЕДЕНИЕ

ГЛАВА 1. КАНОНИЧЕСКИЙ ОБРАЗ БЛАГОРОДНОГО ЧЕЛОВЕКА В КИТАЙСКОЙ КУЛЬТУРЕ ............................................ 8

1.1. Гармоничный облик конфуцианского благородного мужа

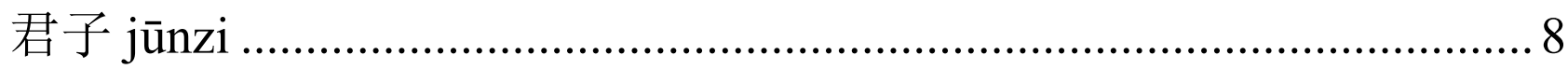

1.2. Основные категории конфуцианства, определяющие

стиль жизни благородного мужа 君子 jūnž̌ ......................................... 16

1.3. Категории 孝 xiào «сыновней почтительности» и 忠 zhōng «верности» как актуальные категории нравственности ....................... 24 ГЛАВА 2. ВОСПИТАНИЕ НРАВСТВЕННОЙ ЛИЧНОСТИ В КНР 32 2.1. Моральные качества 品德 pĭndé и повседневность ......................... 32

2.2. Идеал конфуцианской личности и современность..........................39

2.3. Проблемы нравственного воспитания молодежи КНР ................. 49

ГЛАВА 3. КИТАЙСКИЙ МИР В ЭПОХУ ГЛОБАЛИЗАЦИИ ...........56

3.1. Опыт семейного воспитания в Большом Китае ...............................56

3.2. Женщина в современной конфуцианской культуре........................... 64

3.3. Символические формы поведения современных китайцев...........77

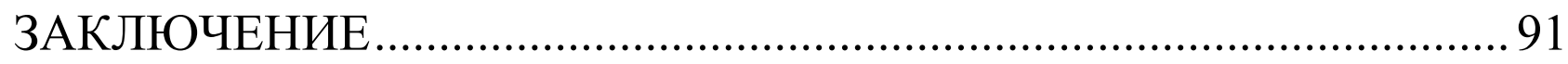

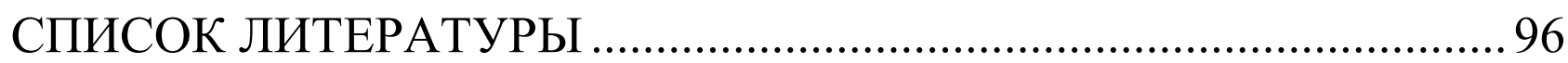

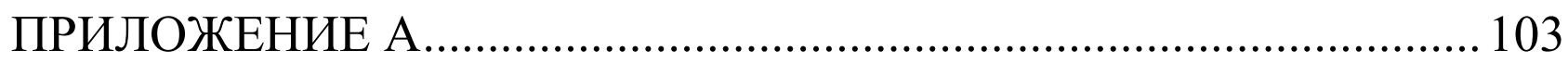

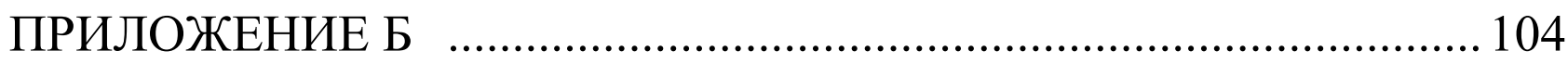

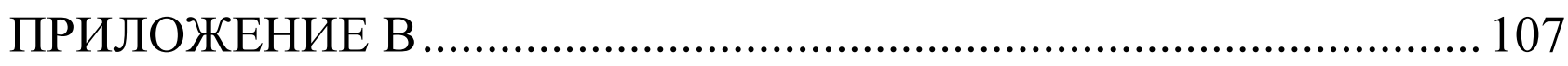




\section{Введение}

В современных условиях глобализации и включении абсолютного большинства стран в этот процесс организация системы нравственного воспитания молодежи в духе национальной культуры является одним из главных условий сохранения традиционных устоев общества.

Формирование высоконравственных идеалов и образцов поведения, которые одобряет и культивирует социум, позволяет носителям традиционных культур противостоять глобализационным вызовам с разной степенью успешности. Власти КНР наиболее эффективно реализуют проекты по созиданию нравственного идеала, гармонично сочетающего в себе приверженность традиционным ценностям и воплощение стремлений и чаяний современного человека.

Свой взгляд на проблему сложения и эволюцию нравственного идеала в китайском социуме в своих трудах излагали отечественные ученые В.В. Малявин [24; 26; 27], А.А. Маслов [29; 30], М.Е. Кравцова [19], И.Г. Баранов [4].Основное внимание этих исследователей сосредоточено на формировании канона человека культуры 文人 wénrén и культе благородного мужа конфуцианского толка 君子 jūnzi. Вопросу культа народных героев эпохи Большого Скачка (1958-1960) и Культурной революции (1966-1976) посвящена достаточно объемная и содержательная работа англоязычного ученого Филипа Шорта [40]. Наиболее глубокие и интересные, с точки зрения фактического материала статьи по исследуемой тематике современного периода, принадлежат перу китайских публицистов Ван Яну [44], Вэю Шушэну[45] и Ли Шуя [47].

Вопрос спецификиэтнопсихологии китайцев детально изучался с конца XIX века; исследования носили описательный характер и были представлены в виде очерков русских и зарубежных миссионеров и участников научных экспедиций. Основополагающие научные труды по проблеме этногенеза принадлежат целой плеяде отечественных исследователей, таких как М.В. Крюков, М.В. Софронов, Н.Н. Чебоксаров, В.В.Малявин, К.М.Тертицкий, Н.А. Спешнев, В.Г.Буров, В.Я. Сидихменов [20; 21; 22; 23; 34;5].

Исследования указанных авторов охватывают различные хронологические рамки становления этнического самосознания китайцев, начиная с 
проблем этногенеза древних китайцев, и до создания Нового Китая; некоторые из работ помогают решить проблемы методологии, в частности, возможности применения различных трактовок понятия «менталитет», «религия», «этнопсихологический феномен» и т.п. относительно особенностей национального характера китайцев. Как в отечественных, так зарубежных исследованиях акцент делается на существование целого ряда факторов, способных влиять на сознание имплицитно, но ощутимо (страх, неудачи, отчуждение, борьба за статус и т.п.). Решающее значение в самоопределении индивидуума имеют базовые факторы (образование, профессия, социальная мобильность, местожительство).

При достаточной изученности проблемы китайскими, отечественными и зарубежными авторами остается широкое поле для анализа способов воспитания китайской молодежи начала 21 века. Актуальность исследования заключается в том, что полевые исследования, проведенные в разных регионах Китая и Тайваня, позволяют добавить существенные штрихи к этнопсихологическому портрету современного китайца и проследить, насколько адаптированы к условиям китайского модернизированного общества нравственные идеалы высокой китайской древности.

Цель нашего исследования - определить основные тенденции эволюции нравственного идеала в континентальном Китае в период конца XX - начала XXI века на основе материалов китайской публицистики. Объектом изучения является нравственный идеал, актуальный в современном китайском обществе, предметом - процессы его формирования и эволюции в новых условиях реализации масштабного строительстваи становления КНР как мировой сверхдержавы. При написании работы нами был применен метод систематизации и анализа материала источников на китайском языке. Наиболее ценным является обзор статей ведущего китайского периодического издания - журнала «Жэньминь хуабао» $[50 ; 53 ; 54 ; 58]$.

Учитывая тот факт, что в исследуемый период в континентальном Китае наблюдаются процессы модернизации личности, мы выдвигаем гипотезу о том, что в китайском обществе под воздействием сразу нескольких факторов, таких как включенность в глобализационные процессы, вестернизация, влияние господствующей идеологии (КПК), намеренно формируется нравственный идеал современной личности, воспитанной в духе 
конфуцианских традиций, успешно адаптирующейся к современным экономическим и политическим условиям страны. Эта личность, с одной стороны, занимает активную жизненную позицию в обществе, с другой, социально мобильна и демонстрирует успешность в разных сферах.

Возникновение типа модернизированного китайца вполне объяснимо и с точки зрения того, что социальная жизнь индивида очень насыщена, а стремление к повышению уровня жизни способствует появлению качеств, которые не были присущи традиционному китайцу. Так, прагматизм межличностных отношений, который, по мнению журналистов Ван Яна и Ли Шуя, проявился особенно ярко в последние три десятилетия, с началом политики реформ и открытости Китая миру, постепенно отодвигает на дальний план такие базовые понятия китайской культуры, как человеколюбие и гуманность; отношения все больше приобретают меркантилизированный характер [50; 54].

Кратко характеризуя идеалы высокой китайской древности, отметим, что образ благородного мужа 君子 jūnzi в традиционной китайской культуре является собирательным и подразумевает, что человек культуры 文人 wénrén всецело стремится соответствовать категориям морали и нравственности, трактуемых тремя учениями 三教 sānjiāo: конфуцианство, буддизм, даосизм. 君子 јӣnziявляет собой некий паттерн идеальной личности, вписанный в картину китайской священной древности и, по сути, представляет собой всего лишь заданный вектор эволюции культуры [1].

Источником исследования послужил сборник сентенций китайской классики под общим названием «Книга о благодетели», изданной в 2006 году в издательстве «Чжунго хуацяо» [1]. В книге представлено порядка 800 крылатых фраз китайских философов классического и среднекитайского периода; цитаты сопровождены комментарием на современном китайском языке и распределены на восемь глав. Все сентенции посвящены толкованию конфуцианских категорий, определяющих поведение в высокоморального человека, воспитанного в духе 美德 měidé, то есть высоких нравственных категорий [56; 863].

Целью исследования является определение степени влияния традиционных китайских категорий в функционировании социальной лич- 
ности в текстах классических текстов и в современном обществе. Поставленная цель предполагает решение ряда задач:

- определить критерии конфуцианского идеала личности;

- дать характеристику основным категориям конфуцианства, определявшим стиль жизни идеального человека;

- выявить актуальность категорий нравственности на современном этапе;

- проанализировать некоторые аспекты воспитания молодежи в духе народного героя Лэй Фэна;

- обозначить круг проблем современного семейного воспитания;

- проследить трансформацию символических форм поведения современных китайцев.

Интенсивные процессы включения Китая во все сферы глобального информационного сообщества, его стремление стать мировой державой, высокая мобильность китайского населения не только внутри страны, но и за рубежом, приводят к переосмыслению традиционных представлений о себе и мире, а также актуализируют заложенные поведенческие паттерны у китайской молодежи.

Анализируя модели отношений внутри семьи, корпорации, общества, китайцы с присущей им прагматикой выделяют те ситуации, которые могут быть реализованы в рамках китайской культуры. Так становится возможным несущественные изменения гендерных ролей, трансформация положения женщины в китайском социуме, увеличение академической мобильности младшего поколения, возвышения места младшего в клане.

Тем не менее конфуцианская культура стойко сохраняет поведенческую матрицу, регулирует нормы поведения, которые соответствуют идеалам высокой китайской древности, значительно адаптированным к современным условиям. 


\section{Глава 1. Канонический образ благородного человека в китайской культуре}

\section{1. Гармоничный облик конфуцианского благородного мужа 君子 jūnzi}

В основе идеальных представлений китайцев о гармоничном обществе лежат «воспоминания» о том, каким оно было в золотое время китайской истории - период правления полулегендарных правителей Китая. Имперская власть представляла собой удивительное сочетание сакрального и мирского, а император, будучи средоточием Вселенной, правил мудро, «свесив рукава, позволяя Поднебесной приходить в равновесие без его вмешательства» [28]. Силы императорской благодати 德 dé щедро распространялись на земли Срединного царства, даруя жителям покой и процветание.

Специфика китайского мышления сложилась в эпоху высокой древности и в общих чертах сохранялась на протяжении веков: китайцы представляют себе этот мир не только как дольний и горний, но и в синхронном сосуществовании всех эпох на одном сакральном пространстве Срединного государства, о чем свидетельствует этимология одной из лексических единиц, обозначающих «время» - 时间 shíjiān, буквально «время и пространство»[56]. Вероятно, такое включение обусловлено особым ощущением течения времени в сознании китайца - сверху вниз, в отличие от принципов развития времени по спирали в представлении западной цивилизации, или ощущением соположения прошедшего времени к настоящему моменту как ушедшего в глубину в русской культуре (ср. «в глубокой древности»).

Древность в Китае почитают и почтительно называют «высокой»-上古 shànggŭ, что свидетельствует о ее «верхнем», по отношению к современному моменту положению. Все, что происходило в древности, канонизировано и возведено в культ. Всякий образованный человек должен уметь оперировать понятиями и знаниями о том, что происходило в прошлом: помнить имена и события (неважно, речь идет добродетельных правителях или махровых злодеях), а так- 
же уметь найти выход из ситуации, ориентируясь на то, как поступали древние. В средневековом Китае даже судебное производство ориентировалось в своих решениях на прецеденты, описанные в священных конфуцианских канонах, что неудивительно: в древности нравы были высокими, а правление - мудрым. Власть передавалась не от отца к сыну, а от правителя к преемнику, обладавшему высокими моральными качествами 德 dé[28].

Общество было построено по типу 小康 xiăokāng, то есть «малого общего достатка», когда семейные кланы живут по принципу соседских общин, у каждого есть всего понемногу, все трудятся на общее благо, люди процветают, мудрый правитель прислушивается к гласу народа, фениксы танцуют, радуя глаз людей, а Небо пребывает в спокойствии, не насылая на народ различные бедствия и катаклизмы. Уже в чжоускую эпоху китайское общество строилось по принципу клановой организации общества 宗族 zŏngzú [30; 149], подразумевающей родство по мужской линии. Кланы имели организующее ядро: культ общих предков и связанные с ними социальные институты. Во главе клана стоял старейшина, совместным хозяйством ведали управляющие, которые избирались поочередно на срок от одного до двух лет. В клановом храме предков хранились генеалогические книги, а на юге Китая существовал и писаный устав клана. Принятые регламенты предостерегали от нарушения норм конфуцианской морали, неповиновении властям, посягательств на частную собственность. Нередко в уставах содержался свод жизненных правил (нельзя «играть в азартные игры», «есть лучшую еду и носить лучшую одежду», «брать много наложниц и служанок, имея сыновей», «позволять женам и дочерям всуе возжигать благовония в храмах» и т.д.) [30;150].Для нарушителей предусматривались воспитательные меры воздействия, самая действенная из которых - исключение из клана.

Кланы были более характерны для деревень, и сосуществовали в соседских общинах. В императорском Китае соседская община была одной из основ общественного и государственного строя. Жизнен- 
ность общинного уклада проистекала из необходимости кооперации крестьянских семей при проведении полевых работ. Так, А.А. Маслов упоминает о применении принципа магического квадрата 罗术 luō shù, проекция которого на обрабатываемое поле отображала воображаемое устройство Земли, в прагматическом назначении. Поле делилось на 9 квадратов, центральный нес некую сакральную нагрузку, представляя собой Срединное государство. Этот квадрат обрабатывали сообща, а лучшая часть полученного с него урожая приносилась на алтарь предков [29; 236].

В Китае встречался особый вид соседских союзов - «деревенский союз 乡约 xiāng уuе̄». Нормы обычного права в деревне, с одной стороны, предусматривали коллективное использование жителями деревни угодий, а с другой - неприкосновенность земельных участков и иной собственности земель. Формы общественной организации зависели от характера поселения. Там, где доминировал один клан, его старейшины осуществляли руководство всей общиной. Преемственность между кланом и соседской общиной засвидетельствована в системе локальных культов. В императорском Китае божественный патрон наиболее могущественного клана обычно почитался как покровитель всей деревни или округа. Иерархия внутри местного общества выразилась в наличии двух уровней локальных культов: культов меж деревенских по своему масштабу и основных по своей публичной значимости, и второстепенных культов, ограничившихся одной деревней или даже кварталом.

В китайском обществе культы всегда были актуальными и остаются таковыми до сих пор. К общенациональным можно отнести культ предков, возникший из культа мертвых, культ Земли, культ Неба, культ учености. Последний тесно связан с конфуцианством и нередко ассоциируется с именем Конфуция и характеризуется четкой ориентацией на знание канонов и почитание письменного сакрального знака 文 wén, по сути - оригинального письма, создание которого приписывается полулегендарным правителям Фу Си и Шэньнуну, а также придворному Цан Цзе[48]. 
Одной из особенностей развития китайского социума является то, что сложная китайская письменность всегда являлось неким ограничивающим фактором, разделявшим общество на ученых и тех, для кого приближение к учености невозможно. Иероглифическая письменность представляет собой фиксацию сакрального знания, которое транслировалось через медиумов и шаманов священным Небом и фиксировалось в пиктограммах на человеческих черепах и костях жертвенных животных. К фиксации допускались жрецы, которые, собственно и явились творцами первой иероглифики. Целый ряд китайских философов считается медиумами, которые сообщали священные знания своим ученикам. Таким образом, уже в древности складывалась особая каста посвященных в сакральное знание, но «первый заметный перелом в осознании сакрального знания, получаемого от духов, происходит в поздний период династии Чжоу (8-3 вв до н.э.)» [29; 203].Служение культу требовало приложения усилий со стороны клана, тщательного выбора времени для отправления ритуалов, а также соблюдения особых правил обращения к животным душам усопших, упокоенных вместе с телом или человеческим, «переселившимся» в именные таблички на алтарь предков в доме. Примечательно, что китайцы порою были на короткой ноге с духами предков: они не молили о богатстве или удаче, а просили совета, добиваясь от духов нужного ответа. В тех случаях, когда духи упорствовали и не способствовали живым, последние могли прибегнуть к угрозе отказаться приносить жертвы.

Имперская власть в Китае активно использовала мистические знания в государственных методах управления. Период Чжаньго (403-256 гг. до н.э.)является одним из самых сложных в политической ситуации древнего Китая, но, вместе, с тем, это время, когда мистические учения постепенно приобретают вид светских политических доктрин, изложенных старым языком, характерным для оккультных школ [29; 305].Попытки осмысления оккультно-магических традиций предпринимались магами и шаманами разных толков. Складывались особые категории, например, магов ии, «служивые мужья», зачастую бывшие выходцами из обедневших аристократических домов. Магам 
ши нередко предлагали сановные должности советников дайфу или почетное место главного советника сян, приближенному к управлению всем царством. Основная миссия их заключалась в поддержании некоего интеллектуального баланса между воинствующей элитой и массой крестьян. Целый ряд замечательных китайских философов, таких как Конфуций, Мэн-цзы, Лао-цзы принадлежали к магам ши [30].

Они путешествовали по Поднебесной, служили при дворах разных правителей, нередко изгонялись или оставляли должность, почувствовав, что государь не прислушивается к их советам. Иногда причиной для ухода могла послужить банальная обида: сам Конфуций всегда следил, какой кусок мяса и в какую очередь ему подавали на пиру. Так он определял степень доверия князя к своей особе.

Именно маги ши заложили особый культурный паттерн ухода «человека культуры» 文人 wénrén от сует бренного мира к чистоте природы, полей и огородов. Крестьяне относились с сочувствием к зарождающейся китайской интеллигенции и поддерживали физическое существование вэньжэнь, так как образ жизни те не меняли, и обрабатывать землю не умели: их предназначение заключалось в следовании выбранному пути. Так складывался канонический образ человека, который служит не правителю, а устанавливает Небесный путь на Земле.

Благодать, которую передавали мудрецы, имела вполне конкретный вид - это набор информации, передаваемый из поколения в поколение. Все великие правители Китая были по существу магическими лидерами настолько харизматичными, что могли объединить людей вокруг культа (Великий сяский Юй, шанский Чэнь Тан, чжоуский Вэньван). Этих людей называли «те, кто пробудил знания 知觉 zhïjué». Знания для древних мистиков являлось чем-то скрыто присущим всем одаренным людям. Вопрос заключается в том, чтобы пробудить эти знания. Вот как высказывался Мэн-цзы о древних мудрых правителях: «Небо породило народ, поставив впереди него тех людей, которые пробудили знания перед тем, кто просто обладает знаниями, для того, чтобы пробужденные, пробудившись, пробудили других» [29; 306]. 
Под магическим знанием понималось особое умение общаться с духами. Его можно было использовать, но не передавать. Известен случай, когда упрек был брошен Конфуцию: «О, феникс, как низко ты пал!» Безумец Цзе Юй указывал Кун-цзы на очевидную неправоту - нельзя посвящать учеников в сокровенное знание. Мудрые уподобляли умение скрыть сакральное с ловкостью торговца, который запрятывает товары в лавке так, что их не видно совсем, но эта пустота и есть намек на полноту запасов.

Познание сокровенного подразумевало умение проникать в мир духов и достигалось в ходе многочисленных даосских телесных и духовных практик. По мнению А.А. Маслова, чжоуская культура сама по себе включала внутренний конфликт: с одной стороны, она была наполнена людьми, которые «странствовали в Дао», с другой, священные знания предназначались узкому кругу избранных, посвященных[30].

Центральной фигурой в эту эпоху стал мудрец, который рассматривался и как философ, и как служивый муж, дающий наставления государю. Характерной особенностью таких советников является умение «учиться, не обучаясь», а черпать эти знания «из себя самого». Всякое знание достигается исключительно из слияния с вещью, проникновения в ее суть и сличения с ощущениями микрокосма.

Мудрец обладает невероятными способностями - «способен осязать то, что не имеет запаха», «странствует с облаками и туманами, разъезжает на луне и солнце», он пребывает в состоянии ничегонеделания. Вероятнее всего, речь идет об ощущениях человека, впадающего в транс, когда его собственная воля бывает отключена. Впрочем, использование соматических напитков было нормальной практикой уже в Шан-Иньский период истории Китая.

Рассматривая наиболее ранний тип китайского мудреца-медиума, следует понимать, что он является исходным вариантом изюньизы, «благородного мужа». Именно умение впадать в транс с тем, чтобы осуществлять путешествия за «пределы четырех морей», то есть реального мира, и есть необходимый навык «благородного мужа». То есть, в мистической трактовке изюньизы - то же самое, 
что маг и шаман, и должен обладать такими навыками опытного шамана, как «юев шаг» (скачущая походка, свидетельствующая о необыкновенных способностях человека) или умением обратиться в птииу (один из обязательных этапов инициации сибирских и китайских шаманов).

Если говорить о светской стороне жизни «благородного мужа», то это образец идеального человека в конфуцианском понимании. Специфика конфуцианства заключается в том, что внутреннее содержание этого учения можно заполнить всем тем, что в данной культуре подразумевается под моралью и нравственностью. Такое «удобство» делает учение Конфуция необыкновенно притягательным для азиатских культур, так как дает широкий простор для того, чтобы помочь учению реализовать главную цель - использовать человека в целях служения обществу.

Кун-цзы часто говорил о том, что ученый должен быть «приятен снаружи и любезен внутри». В этой фразе содержится намек на то, что изюньцзы соблюдает установления ритуала 礼 lı̆ не только на людях, когда он должен быть одет согласно предписаниям, но и знать, как сесть и встать, что говорить даже тогда, когда он находится во внутренних покоях своего дома. Известен курьезный случай, произошедший с Мэн-цзы, воспитанным образцовой конфуцианской матерью: он без стука вошел в женские покои и застал свою супругу небрежно одетой. Раздосадованный увиденным, Мэн-цзы обратился к своей матушке с прошением разрешить расторгнуть брак, однако получил урок повседневности. Мать Мэна из Цзоу прямо указала ему на проступок, ибо следовало не обвинять жену в не следовании ритуалу, а самому помнить, что прежде чем войти, надо стучаться в дверь [2].

«Благородным мужем» мог стать каждый, но была необходима решимость стать им. Это значит, что кандидат должен обладать не только нерушимой волей, но и стойкостью духа, которая поможет ему выстоять в медиативных странствиях в иных чертогах. Цзюньизы верно служит конфуцианским идеалам, и вместе с тем способен спокойно принять даже мученическую смерть, так как согласно даосским представлениям, он очищается и обретает бессмертие на Великом Пути. 
«Благородному мужу» противопоставляется человек низкий - 小 人 xiăo rén. Такая антитеза необходима для того, чтобы показать образец правильного поведения: под ударами судьбы низкий человек ропщет против воли Неба. Он не знает этикета (ритуала), а значит, не слышит слов мудрого. Он презирает тех, кто стоит выше его по социальному положению и не обладает человеколюбием. «Благородный муж» гуманен, он не противится чужой воле, но подобно траве, низко склоняет голову, когда дует сильный ветер. Цзюньизы стремится добру, а значит, его окружают добрые люди, которых он ставит выше себя, памятуя о заветах мудрых правителей древности. Так, в сборнике «Книга о благодетели» упоминается:

致君尧舜上, 在使风俗浮。ZhìjūnYáo Shùnshàng, zàishǐfēngsū fú $[1 ; 7]$.

Во имя того, чтобы нравы становились высокими, благородный муж ставит имена первых правителей Китая превыше своего.

В этом высказывании присутствует столь любимая китайцами отсылка к идеалам высокой древности, к эпохе правления императора Яо, прославившегося своим простым образом жизни и человеколюбием, а также к к его преемнику Шуню, который не только проявлял чудеса толерантности и сыновней почтительности, но и наследовал трон благодаря тому, что мудрый Яо оценил по заслугам его высокие моральные качества. Изречение принадлежит знаменитому поэту династии Тан Ду Фу и стало крылатой фразой.

Образ «благородного мужа» может включать в себя два уровня восприятия - повседневный, представляющий собой образец светского поведения конфуцианца, и мистический, тот самый, который позволяет отделить суетное от праздного, простого человека от мистика и медиума, включенного в круг посвященных в сакральные знания Великого Пути и благодати. Благородный муж стоит выше, чем те границы, которые предписывают ему конфуцианство, буддизм или даосизм, это явление всеобъемлющее:

君子虽在他乡，不忘父母之国。Jūnzĭ suí zài tā xiāng, bù wàng fùmŭ zhīguóo $[1 ; 9]$. 
В этом высказывании минского литератора Фэн Мэнлуна трактуется еще один принцип поведения благородного мужа - будучи даже в чужих краях, не забывать о долге перед Родиной. В этой фразе имплицитно присутствует отсылка к известному сюжету, за основу которого взяты реальные события обстоятельства путешествия в Индию танского монаха Сюаньцзана за священными сутрами. Вообще, nутешествие можно толковать и с точки зрения мистики, например, медиативные путешествия даосов, и как реальный путь за буддийскими сутрами группы сподвижников Сюаньцзана. И в том, и в ином путешествии благородный муж мыслится в категориях долга и верности усвоенным нормам поведения - скромности (он непритязателен), непротивления внешним силам (за него это делают другие), искренности (он действительно верит в свое предназначение), избранности (по праву приобщения к новому, набирающему популярность учению) и т.д.

Такие тщательно продуманные нормы поведения, оформленные в конфуцианские догматы, не требующие осмысления, но точного знания, как поступить, как реагировать, как передавать знания, сыграли важную роль в формировании китайского менталитета.

\section{2. Основные категории конфуцианства, определяющие стиль жизни благородного мужа 君子 jūnž̌}

Роль Конфуция в создании учения о соотношении личного и общественного в китайском обществе трудно переоценить: он был первым философом, который четко сформулировал критерии нравственности и ответственности индивида перед обществом. Мораль коренится в присущей человеку воле к совершенствованию, заключающейся в преодолении себя kѐjì- 克己. Смысл преодоления заключается в том, чтобы уменьшать эгоистические наклонности и воспитывать способности к трезвой самооценке. Если индивид достигает этого, Поднебесная процветает: 克己福利 kèjǐ fúlì, ибо тогда вселенная откликается на малейшее изменение и приходит в гармоничное состояние. 
Созданная конфуцианством культурная матрица не могла дать трещину и допустить внедрения чуждых инокультурных компонентов ровно до тех пор, пока не стала уязвимой в степени утраты индивидуумом ответственности перед обществом, когда человек полностью сосредоточился на себе и своих личных ощущениях, забыв о долге. Такой уловкой и воспользовались европейцы, стремившиеся насильно открыть миру императорский Китай путем наркотизации китайского населения в середине XIX века.

Принцип моральности знания, введенный Конфуцием, утверждал преемственность внутреннего опыта человека и его общественного положения: внутренняя работа и самосовершенствование непременно выражалось в «достойном облике». Такие метаморфозы не могли произойти, если конфуцианский подвижник не обладал одной из главных конфуцианских добродетелей - искренностью 诚 chéng, подразумевающей адекватность самооценки, справедливость его отношения к другим [29, 196].

Сама личность рассматривалась китайцами в двух очень разных, но связанных между собою измерениях: с одной стороны она предстает частью клана, непосредственным опытом присутствия физического тела gŭròu 骨肉. Обстоятельство телесной принадлежности семье формирует специфическое отношение человека к своему телу: его надлежит беречь, дабы проявлять сыновнюю почтительность к родителям, давшим жизнь. Порою следование этой конфуцианской традиции играет с китайцами злую шутку. Стремление обеспечить своему физическому телу избавление от отработанных энергетических частиц 气 qì сподвигает конфуцианца к проявлению бытовой некультурности - отправлению естественных нужд или плевка в общественных местах. На уровне культурной корреляции такое поведение совершенно нормально у китайцев, но вызывает культурный шок у иностранцев.

С другой стороны, человек вовлечен в сеть социальных отношений, он чаще не личность, а социальное лицо. Категория лицุа 面 miàn - понятие не врожденное, а приобретенное, над его сохранением 
надлежит работать, его можно потерять помимо своей воли. В рамках этики лиц̧а человек не должен вступать в соперничество или преследовать какие-либо цели для себя.

Потеря лица - общественная смерть индивида. Человек, уличенный в безнравственном поступке должен доказать свою невиновность, признать свое несовершенство. Отсюда происходит характерное для китайской цивилизации настойчивое утверждение скромности и бескорыстия как наивысшая благодетель. Человек не мог рассматриваться сам по себе, он был включен в стройную систему взаимодействия не только с социумом, и «осмыслялся в категориях преемственности и гомологии между человеком и космосом», что вполне соответствовало классическому китайскому пониманию гармоничного симбиоза человека и природы, в то время как европеец вынужден был с ней бороться, побеждая, чтобы отвоевать свое право на существование[27].

Начало мира описывается классической китайской фразой: «一 生二, 二生三,三生万物》 yī shēng èr, èr shēng sān, sān shēng wàn wù, что толкуется как «единица рождает двойку, от двойки рождается тройка, тройка рождает десять тысяч вещей, то есть все, что окружает нас». Под тройкой можно рассматривать триаду Небо-Человек-Земля. Среди «десяти тысяч» вещей и существ человек рассматривается как самое одухотворенное, и даже как «семя мировых стихий», средоточие мирового круговорота. Человеку, занимающему срединное положение в триаде, надлежало найти свое место и жить, не нарушая ритма дыхания вселенной.

По мнению В.В. Малявина, в таком образе человека угадываются архаические мотивы антропокосмоса, вселенского первочеловека. Китайская мысль признавала субъективность, однако трактовала ее как меру осознания человеком своей бытийственной полноты. Так становятся понятны и вполне справедливы прописанные в канонах базовые категории конфуцианства, призывающие последователей этого учения соизмерять долю своего присутствия и влияния как на внешний мир, так и все то, что направлено извне [25].Одним из центральных понятий становится гуманность 仁 rén, включающая не 
столько любовь к ближнему, сколько доброе отношение вышестоящего к нижестоящему. Образец для подражания также существует в высокой китайской истории, речь идет об одном из первоправителей Поднебесной - Яо.

Мудрый государь китайской древности Яожил в простой тростниковой хижине и питался грубым рисом. Из любви к своему народу он обращался к небесным силам за помощью, когда его собственные ресурсы в противостоянии природному катаклизму были исчерпаны. Об этом красноречиво рассказывается в солярно-лунарном мифе о Стрелке Хоу И, наказавшем непослушных сыновей-солнц Ди-цзюня. Император Яо не перепоручает разрешение проблемы стрелку И, этакому воплощению воинского начала 武 wŭ,oн проявляет житейскую мудрость, подослав мальчишку вытащить последнюю стрелу из колчана, благодаря чему Хоу И не расстреливает последнее непослушное солнце [48].

Под стать мудрому Яо и другие правители мифического периода китайской истории, например, Великий Юй, управлявший водами. Исследуя этимологию происхождения иероглифа 治 zhì, можно утверждать, что тот, кто управляет водами, тот способен управлять Поднебесной. Великий Юй справился с задачей усмирения потоков, и за много лет своей деятельности на благо народа трижды мимо дома ходил, ни разу не заглянув к родным. Его долгом было заботиться о народе, об этом упоминается в «Шаншу», в разделе о «Деяниях Великого Юя»:

德惟善政, 政在养民。Dé wéi shàn zhèng, zhèng zài yáng mín.

Добродетель заключается в гуманном правлении, править - значитвос-питывать народ $[1 ; 43]$.

Государь должен быть не только гуманен, но и следовать долгу 義 уі̀, то есть ставить интересы других превыше всего, в частности, это можно истолковать из написания иероглифа: жертвенные бараны (животные) приносятся высшему божеству, а «мои» интересы ставятся ниже. Так же толкуется и «доброта» 善 shàn, в циньском варианте которого наверху изображаются два «человека», что можно рассмат- 
ривать также как удовлетворение интересов и выгоды простых людей раньше (выше), чем своих собственных (см. Приложение А).

Просвященный должен владеть категорией 智 zhì, «мудростью и пониманием». Под мудростью понимается не только знание как способ выхода из житейских ситуаций, но и постоянная поверка этих знаний с волей неба, поэтому внизу иероглифа «мудрость» располагается графема «солнце». Напомним, что Конфуций сам не раз призывал своих учеников заниматься 复习 fùxí , то есть многократным обращением с вопросами к Небу, так как это делали китайские маги, шаманы и гадатели. Толкование значения 習 хí включает в себя не только «многократное повторение», но и «птица, многократно летающая к Небу».

Государь ценился у китайцев тем, что он по рождению обладал «благодатью» 德 dé. Это очень многогранное и сложное для представителей европейской цивилизации понятие, которое может толковать как «благоприятные флюиды, благая сила, благодеяние». Одним словом все то, благодаря чему дышит и живет Поднебесная. Именно потому, что китайский государь являет собой особый тип медиума, способного общаться с духами предков и слышать волю Неба, он призван расточать свою благодатную дэ на священный пятый (срединный квадрат) китайской картины мира. Окраинные квадраты, расположенные за пределами китайской ойкумены, не дополучают благодать государя (позже - императора), поэтому правление там негуманно, люди живут по варварским законам и не знают ни долга, ни справедливости.

К слову, тем императорам, которые узурпировали власть, то есть пришли к ней не по праву рождения, приписывалось необычайное происхождение, которое давало приобретенную способность расточать благодать на своих подданных. Так, придворные советники настоятельно рекомендовали основателю Ханьской династии Лю Бану присмотреться к тотему дракона, и даже убеждали его, что за 10 лун до его рождения во дворе дома видели дракона, в момент рождения будущего императора являлся дракон, а в гневе он сам был очень похож на дракона. По сути, император был сам дракон, такая оценка 
имеет яркую положительную коннотацию, учитывая, что дракон считается властелином воды.

По мнению А.А. Маслова, китайский император никогда не считался человеком или мужчиной, хотя антропологически так и было. Он, скорее, представлял собой медиума, сосредоточие мистической силы 阴 yīn, и одной силой мысли мог возвращать к жизни души умерших китайцев, несущихся в сакральном Желтом потоке 黄泉 Huáng quán [29]. Одним из признаков утраты благодати дэ было отсутствие в двух последних поколениях прямых мужских потомков, что было своеобразным сигналам черноголовым к тому, чтобы низвергнуть своего государя. Впрочем, такой неожиданный переход из области сакрального в самое что ни на есть реальное, вполне в духе китайцев: на вопрос, а что же собственно такое Желтый поток, они указывают на талый снег и вешние воды.

Если правление императора было угодно Небу, то оно не посылало на Поднебесную никаких катаклизмов, а в мире царили гармония и согласие 和 hé, в современном китайском обществе толкуемая как «гармония и способность прийти к компромиссу», тщательно культивированное понятие 协和 xiéhé.

Ныне к тем самым медиаторам относят пожилых и уважаемых людей, которые способны уговорами и убеждениями примирить враждующие стороны едва наметился конфликт. В настоящее время ведется активная кампания по популяризации таких самостоятельно организованных комитетов в городах, а в древности признаком гармонии всегда были танцующие фениксы.

Не только государю, но и всякому, кто жил по канону китайского интеллигента, следовало ощутить свое место в потоке Дао. Под Дао подразумевают тот самый Путь вещей, некая виртуальная природа человека. Как отмечает В.В. Малявин, в даосской традиции «подлинный человек Дао» предваряет мир, и мир творится по его подобию. Дао-человек питается от Матери мира, и «дышит из пяток», будучи открытым виртуальному совершенству одухотворенной жизни. Каждое мгновение он перерастает сам себя и изливается в мир, его 
бытие - непрестанное превращение. Жизнь Дао-человека есть полная открытость зиянию бытия, встреча пустоты с пустотой. Подлинной субстанцией тела китайцы считали именно пустоту в нем. Об этом свидетельствует принятое в китайской литературе метонимическое обозначение тела как «девяти отверстий», знаменитое учение о жизненных точках организма, представляющие собой отверстия энергетических каналов, через которые в полое-полное тело течет вселенская энергия и из него же вытекает [25].

Поэтому человеку нужно чутко чувствовать свою сопричастность ко всему, что происходит внутри и вокруг него, так как он неотъемлемая часть Бытия и Небытия. Вообще, о Дао не может сказать никто, как говорится: 《道可道非道》 dào kě dào fēi dào - «Если о дао можно говорить, это не дао» [1].

Китайская философская мысль утверждает, что человеческие чувства также принадлежали внешнему миру до такой степени, что даже камни считались результатом превращения сокровенного чувства. Отсюда происходит один из известных ландшафтных приемов, практикующихся китайцами по сей день - высечение на камнях цитат или собственных глубоких мыслей и установление таких природных камней в различных общественных местах.

Самопознание в китайской культуре состояло в охвате сознанием всей полноты жизненных качеств человека и требовало преображение внутреннего мира человека. Это предполагает сосуществование и взаимозависимость интеллекта и чувственной жизни человека, а также мастерства 功夫 gōngfū в работе над собой. Такое взаимодействие сердца и мысли приводило к прояснению сознания: чем сильнее и искреннее мысль, тем она яснее и благотворнее для сознания. Сверяясь с гармонией внешнего мира, человек достигал гармонии внутри.

Конфуцианство толковало мысль и чувство как некий симбиоз и предостерегало от чрезмерной приверженности только чувству или сознанию, даосское и буддийское учение трактовало возможность достижения просветленности посредством крайнего возбуждения чувств, нередко отождествляемого со сновидением [25; 185]. К эпохе 
Тан в литературе стал популярен жанр волшебных новел, в котором герою предстояло погрузиться в состояние сна-морока, чтобы пережить несколько калп и обрести бессмертие. Зачастую ученик не выдерживал самого последнего испытания - любви матери к своему чаду, и если привязанность к земному брала вверх, о бессмертии нечего было и думать. Самосовершенствование также происходило во сне или достигалось путем многочисленных практик, в том числе и созерцательных. В эпоху поздних империй эта идея перешла в светскую культуру, дополнив паттерн жизни китайского интеллектуала целым рядом прекрасных занятий: любование цветком, поклонение антикварной вещице, слушание звона яшмы.

Вся жизнь китайского интеллигента как до эпохи Тан, когда произошло окончательное оформление канона человека культуры вэньжэнь, так и после падения этой блистательной династии, была расписана по канону, строго регламентирующему, как вести себя, как разговаривать, как встать, как есть, как развлекаться и заниматься достойным времяпрепровождением, и эти правила создавались с оглядкой на базовое понятие конфуцианства - категорию ритуала 礼 lı̌ [2].

Под ритуалом 礼 lĭ, как говорилось выше, подразумевалось правильное поведение человека в угоду не только устоявшимся обычаям, но и в духе образцовкитайской древности. Обладая таким мощным инструментом, как конфуцианские категории, становилось возможным управлять огромными массами людей, убежденных в правильности происходящего.

Ритуал гармонично обустраивал не только бытовую сторону жизни китайца - когда младший или находящийся в более низком положении подчинялся старшему или пожилому, но и предполагал наступление столь желанного момента, когда и младший становился старшим, и ему были положены все почести и выгоды. Оттого китайские дети и взрослели так быстро, а китайский костюм не знал своего детского варианта вовсе - детей одевали как маленьких взрослых.

Ритуал 礼 lǐ обозначал главным признаком человека его моральное сознание, которое он был призван в себе развить и стать 
цзюньцзы, или наоборот, подавить в себе мораль и опуститься до скотского состояния.

Поскольку знание моральных принципов («долг», «справедливость», «ритуал» и т.д.) передавалось человеку с воспитанием в семье и обществе, он должен был отпустить на волю свой разум, совершенствование предполагалось в раскрытии его природных задатков.

Конфуцианцы нередко расходились в своих мнениях на главный отличительный признак человека, так Сюньцзы видел его в способности людей жить сообща, в коллективе. Дун Чжуншу утверждал, что признак человека в его подобии Небу, а значит в его превосходстве над всей живой природой. Тем не менее официальная точка зрения конфуцианства все же транслировалась как в подчинении Земле и Небу как отцу и матери, гармоничному включению в эту триаду. Эта же идея лежит в концепции соответствия сердца совершенного мужа изюньизы зерцалу мудрости, в бездонной пустоте которого выявляется и получает завершение все существующее.

Назначение человека, согласно Конфуцию, состоит в том, чтобы «убрать свое субъективное я», в то время как даосы призывали растворить это я в мире. Таким образом, «настоящий человек», принадлежащий традиции даосизма и благородный муж изюньцзы в конфуцианстве обозначают два полюса человеческого совершенства: полноту бытия, постигаемую во внутреннем прозрении «раскрытого сердца» и безупречную гармонию его существования в социальных и универсальных отношениях. Положение в обществе подразумевало следование основным конфуцианским категориям, актуализированным к условиям и специфике китайскойповседневности.

\section{3. Категории 孝 хіа̀о «сыновней почтительности» и 忠 zhōng «верности» как актуальные категории нравственности}

Достаточно сложно дать четкое понятие морали и нравственности не только у представителей разных цивилизаций, но и у одного и того же народа в разное время. Так, в западной цивилизации оперируют понятием нравственности как «специфическим типом регуля- 
ции отношений людей, направленным на их гуманизацию; совокупностью принятых в том или ином социальном организме норм поведения, общения и взаимоотношений» [3].

Мораль, как правило, выступает в качестве «неписаного закона», реализуя свою регулятивную функцию в первую очередь посредством обыденного сознания на уровне повседневности. Генетически мораль восходит к феномену обычая, применительно к индивиду основные нравственные ценности усваиваются им в процессе личностной социализации. Так как все отношения людей проникнуты нравственностью, они подвергнуты оценке и проходят проверку на жизненную целесообразность. Традиционно транслятором моральных принципов является старшее поколение, стало быть, за ним усматривается право ее установления.

Как утверждает А.Н. Мещеряков, вектор развития большинства восточных обществ до недавнего времени был направлен на старшее поколение в ущерб младшему. Это можно легко доказать, просмотрев некоторые средневековые медицинские трактаты. В них можно присутствуют целые главы, посвященные уходу за пожилыми людьми, но нет ни слова о том, как ухаживать за младенцами [31;284].

Китайская литература пестрит конфуцианскими поучительными историями о том, как почтительный сын среди грозы кидался на могилу матери с криком «Мама, не бойся!», так как при жизни она боялась громовых раскатов, а другой почтительный сын подставлял свое тело комарам, чтобы они не питались кровью его родителей[2;10].С точки зрения западной и русской морали такое поведение вполне укладывается в рамки нормального, а вот некоторые другие, такие как пожертвование жизнью младенца ради обеспечения пропитания престарелой матери, кажутся нам стоящими за гранью добра и зла.

В старом китайском обществе дни рождения отмечали только очень пожилым людям, поэтому и существует традиция подношения имениннику 寿面 shóumiàn длинной лапши долголетия, а в современном китайском социуме детские дни рождения празднуют не так давно, не более 20 лет. Вектор постепенно поворачивается в сторону нового, молодого поколения. Политика ограничения рождаемости, даже 
после поправок 2013 и 2015 года все же достаточно регулирует прирост ханьских семей, а как результат, самым главным человеком в клане становится драгоценный малыш 宝宝 băobao, окруженный большой китайской семьей. Однако проблемы взаимоотношения старшего и младшего поколения не только существуют, но и нуждаются в регулировании.

Китайское общество живет по четко выстроенным правилам взаимоотношений, когда мнение старшего поколения считается окончательным и обсуждению не подлежит. Это способно сплотить семью, особенно если учесть, что китайцы традиционно живут тремя поколениями вместе, и лишь небольшой процент молодых семей проживал отдельно не в связи с трудовой занятостью в другом районе, регионе, провинции, а по собственному желанию (материальным возможностям). Со стремительным ростом благосостояния китайского населения благодаря успешному осуществлению модернизации, все больше китайских семей предпочитают проживать нуклеарной семьей в собственной квартире, но по соседству с родственниками в одном доме.

Приоритет мнения старшего бесспорен, и наличие пожилого человека в семье считается богатством, о чем свидетельствует пословица:

家有一个老就像有一个宝。Jiā yŏuyí gè lăo, jiù xiàngyŏuyígè băo.

«В семье старик - что драгоценность».

Тем не менее, «драгоценным» в последние 20 лет называют и ребенка, упоминавшееся выше 宝宝 băobao, и даже продаваемую вещицу на сайтах интернет-магазинов типа Таобао 淘宝. В данном случае упор делается на самоценности факта обладания членом семьи или вещью.

Категория сыновней почтительности 孝 хіа̀о включает не только взаимоотношения отцов и детей, но и широко применима в обществе вообще. Так, в старом Китае жена подчинялась мужу, а если учесть, что «свободных» женщин в Китае не было никогда, то женщина подчинялась мужчине. После смерти мужа она следовала советам сына, но по большому счету, являлась представителем старшего поколения, а значит, последнее слово оставалось за ней. В свою очередь «идеальная» жена должна была совершить ритуальное самоубийство, а 
власти даже брали такие семьи на обеспечение. В более прозаичных случаях ожидалось, что женщина больше не выйдет замуж, так как « 好女子不喝两个家的婚茶》 hăonv̌zi bù hē liănggè jiāde hūnchá, то есть «хорошая невеста два раза замуж не выходит».

Как свидетельствует А.А. Маслов, дочерняя почтительность в некоторых случаях переходила все границы того, что с точки зрения русского человека и европейца (уже под вопросом) считается просто абсурдным: существовал ритуал перехода из женского в мужское, так называемый 阴阳交 yīnyángjiāo, когда девушка принимала особые пилюли, прекращавшие ее естественный цикл ежемесячных выделений и она могла осуществлять все обряды, связанные с культом предков [29; 205]

Подчинение младшего старшему не ограничивалось кругом клана или семьи - оно пронизывало все общество, создавая многочисленные подчиняющие связи вертикально и структурируя социум на каждом ярусе.

Так, ученик подчинялся учителю, и тот мог воздействовать на ребенка физически. Об этом свидетельствуют не только сохранившиеся в китайской школе меры воздействия - от наказания легким ударом линейкой по рукам до долгого сидения сцепив руки сзади. Иероглиф 教 jiāo также свидетельствует о наличии двух важных компонентов обучения: «сыновней почтительности» и «побивания» (графемы соответственно слева и справа).

Подчинение 孝 хіào предписывало особый стиль поведения младшего, когда нельзя было начать трапезу или разговаривать раньше, чем это делает старший. Общаться со старшим следовало сидя на коленях, а в случае, когда младший провинился, то руки располагались вытянутыми по направлению к старшему, так в китайском языке сложилось понятие 对不起 dùibùqŭ, буквально «не сметь подняться», в современном языке переводимое какэтикетное «извините».

Конфуцианская категория почтительности охватывала все общество, а не только слой интеллигенции вэньжэнь, о чем свидетельствует следующая сентенция: 
家贫知孝子, 国乱识忠臣。Jiā pín zhī xiào zĭ, guó luàn shi zhōng chén $[1 ; 45]$.

И в бедных семьях растут почтительные сыновья, и в годы смуты государству служат верные сановники.

Категория сыновней почтительности 孝 хіàо дополняется категорией верности, преданности 忠 zhōngи веры 信 xìn. Так, Фэн Мэнлун вопрошает:

不忠不信,何以立于天地之间? Bù zhōng bù xìn, héyǐ lì yú tiāndi zhījiān?

На чем будет стоять Поднебесная, если не будет ни верности, ни веры?

Благополучие Поднебесной зиждется на том, что каждый вносит своей посильный вклад в общее дело, а не просто надеется на поддержку общества, так говорится в установлениях «Цзочжуань»:

民之多幸, 国之不幸。Mín zhī duō xìng, guó zhī bù xìng [1;48].

Мо-цзы увещевает: «(Гармония достигается) только взаимной заботой, обоюдной выгодой и уступками, которые жители (Срединного государства) делают друг другу»:

兼相爱,交相利。Jiān xiāng ài, jiāo xiānglì $11 ; 46]$.

Хань Ин и вовсе призывает к почти христианскому непротивлению злу насилием:

人善我,我亦善之; 人不善我, 我亦善之。Rén shàn wŏ, wŏ y⿺ shànrén,rénbù shànwŏ,wŏ yĭ shànzhī.

Люди окружают меня добротой, и мои намерения к ним добры; если же относятся ко мне нехорошо, я все же отплачиваю им добром $[1 ; 49]$.

В исследуемом источнике высказывания объединены в восемь больших разделов: 忠篇 «Глава о верности и преданности» (54 иероглифических страницы), 孝篇 «Глава о сыновней почтительности» (20 стр.), 智篇 «Глава о мудрости» (66 стр.), 勇篇 «Глава о доблести» (60 стр.); 礼篇 «Глава о ритуале» (44 стр.), 义篇 «Глава о долге» (36 стр), 廉篇 «Глава о чистоте» (12 стр.), 耻篇 «Глава о постыдном» (15 стр.) 
Книга предназначена для широкого круга читателей, и такое объединение цитат и комментирующих их поучительных историй неслучайно: краеугольным камнем конфуцианского учения все же является учение о любви к Родине и служению ей, а для этого нужно четкое структурное подчинение в обществе, включая и семью, как базовую социальную ячейку; необходимо понимание мудрости старшего поколения и, наконец, воспитание на эпических примерах древности.

Несмотря на то, что по объему главы разнятся, значим тот факт, что автор сборника Вэй Пуфэн располагает информацию именно в таком порядке, от главного к второстепенному. Красной линией проходит идея подчинения и почитания. В межличностных отношениях приоритет имеет мнение старшего, в отношениях между гражданином и государством безусловный авторитет остается за последним. Примечательным фактом остается намеренное (?) упущение прецедентного высказывания о том, что бунт против государства оправдан, если оно притесняет «моего» отца. Впрочем, оно было на пике популярности в годы культурной революции, и было актуализировано Мао Цзэдуном, обращавшимся к юным маоистам.

Итак, первая глава источника делится на четыре параграфа, последовательность которых также подтверждает нашу гипотезу о расстановке акцентов воспитания в китайском обществе:

- 热爱祖国 rè ài zúguó «Любовь к родине»

- 尽忠职守 jìn zhōng zhí shŏu «Беспредельная преданность и соблюдение долга»

- 诚实守信 chéng shí shŏu xìn «Искренность в делах и соблюдение веры»

• 敬天爱人 jìng tiān ài rén «Уважение воли Неба и гуманность» Вторая глава содержит два параграфа:

- 孝敬父母 xiào jing fùmŭ «Почитание родителей и подчинение им»

- 以己推人 yĭ jí tuī rén «Свое поведение - лучший пример»

Если первые главы содержат в себе базовые понятия, выделяемые нами условно, так как они, конечно же, усваиваются китайцами в сложном комплексе нравственных установок, то последующие главы содер- 
жат уже прямое наставление к действию, что позволяет нам переводить в императиве. Итак, третья глава включает в себя побуждения:

- 重教好学 zhòng jiào hăo хué «Учись, всецело отдавая себя учению»

- 追求真理 zhū qiú zhēn lǐ «Следуй истине»

- 明辨是非 míng biàn shi fēi «Различай и разграничивай»

- 重视人才 zhòngshì réncái «Развивай свои дарования»

- Четвертая глава структурно поделена на параграфы:

- 自强不息 zì qiáng bù xī «Неустанно укрепляйся»

- 修身立德 xiū shēn lì dé «Совершенствуйся и утверждай силу благодати»

- 志向远大 zhì xiàng yuăndà «Проявляй волю к большим свершениям» Пятая глава делится на параграфы:

- 依礼而立 yī lì ér lì «Опираясь на ритуал, живи по ритуалу»

- 重视规范 zhòng shì guīfàn «Уделяй внимание обстановке»

- 合同众人 hé tóng zhòng rén «Будь с народом» В шестой главе всего один параграф:

- 维护正义 wéi hù zhèngyì «Защищай справедливость» В седьмой:

- 正直无私 zhèng zhí wú sī «Стремись к бескорыстию»

- 廉洁奉公 liánjié fènggōng «Будь честен с другими» В заключительной главе, посвященной понятию стыда, два параграфа, которые скорее вдохновляют, чем укоряют:

- 有所不为 yŏu suŏ bù wèi «Делай, что должно»

- 知耻近勇 zhī chĭ jìn yŏng «Признание ошибки - уже смелость» Каждая глава источника содержит несколько сентенций на классическом языке с обязательной отсылкой к автору крылатой фразы и указанием источника, откуда они взяты. Прилагается комментарий на современном китайском языке и лаконичная история происхождения той или иной фразы.

Образ благородного мужа цззюньцзљы в современной китайской культуре является собирательным и подразумевает следование тем 
категориям, которые присутствуют во всех трех сегментах китайского бытия: конфуцианство, буддизм, даосизм.

Эти основные категории предполагают воспитание человека, независимо от его социального происхождения, в духе безоговорочной любви к Родине, почитание устоев китайского общества, гармоничного сосуществования. Человек не только осознает свое место в государственной или семейной иерархии, но и занимает это место, отведенное ему свыше время до тех пор, пока он не переходит в поколение старших или занимает более выгодное общественное положение. Проще говоря, строгая система подчинения, нашедшая выражение в категориях сыновней или дочерней почтительности, на бытовом плане выглядит не столь привлекательно, тогда, когда представляется как визитная карточка китайской культуры миру.

При всей своей недостижимости и отдаленности во времени, идеал благородного мужа, тем не менее, остается актуальным и реализуется в области нравственного воспитания школьников. Так, в национальной школе, начиная с первого класса младшей ступени, учащимся дополнительно предлагают к заучиванию наизусть небольшие квинтэссенции из популярных китайских словников, например, «Троесловие» (Саньцзыцзин, «三字经》), в котором доходчиво, благодаря комментированию на путунхуа, приводятся весьма поучительные рассказы о благородных или несправедливых поступках героев древности. Например, в интерактивном учебнике «Троесловия» красочно представлены истории о детстве философа Мэн-цзы и его благодетельной матери, приложившей немало усилий для воспитания Мэна из Цзоу в духе конфуцианской догмы [55;10]. В комментировании акцентируется внимание на жизненность древних постулатов, в каждом из комментариев содержится посыл реализовать себя в общественной жизни путем прилежного обучения.

Для среднего и старшего школьного возраста предлагается литература, такая, как «Книга облагодетели», когда уровень восприятия классического языка позволяет работать со сложным языковым материалом. 


\section{Глава 2. Воспитание нравственной личности в КНР}

\section{1. Моральные качества 品德 pĭndé и повседневность}

Определение критериев нравственности в разных культурах требует тщательного анализа, прежде всего того, что есть человек в той или иной традиции.

Так, по мнению В.В. Малявина, человек в китайской традиции «не мера, а глубина всех вещей» [25;539]. Эта глубина скрывает себя в спонтанном неразличении света и тени, внутреннем ощущееии «костей и плоти»骨肉 и внешнего ичеремониала отражений.

Человеческое в китайской культуре - антропогенная, человекопорождающая реальность, так человек культуры вэньжэнь открывал себя, уединяясь от мира. Конфуцианский благородный муж должен был своим примером помогать «вымести всю грязь светского общества», а буддисты и даосы не снимали ответственности с человека, если он совершал грех во сне [30]. Это можно понять, если уяснить для себя известное толкование жизни человека как существующую реальность (наяву) и морок-наваждение (во сне). Анализ паттерна сна-морока помогает усвоить некоторые подходы к измерению разных явлений и легко укладывается в парадигму взаимодействия противоположностей. Итак, люди едины по пределу своего существования, и этот предел - типизированная форма, жест, который принадлежит всем и никому в отдельности.

Ритуал в китайской культуре не только упорядочивает отношения между людьми, но и свидетельствует о недостижимом духовном опыте, зеркально отражающем наше эмпирическое познание. Ритуальность в Китае поставлена обособленно, так как она призывает включение не индивидуального, а общего. Если в западной традиции ритуал подразумевает понятие индивида, то в китайской традиции личности, как неделимой сущности не существует, так как каждый имеет значение не по отдельности, а только как маленькое стеклышко общей картинки калейдоскопа. 
В Китае личность рассматривалась как аналог тела, воплощавшего принцип множественности миров. Телесность в китайском представлении - это сложная сеть энергетических каналов и точек, что является зеркальным отражением глубины вселенского Хаоса, состоящей из разрывов и непоследовательности [24; 539]. Китайская традиция признает две стороны личности - биологическую и социальную, что отражается во множестве противоречивых обычаев и представлениях. Так, возраст ребенка ведется с момента зачатия, но в старом Китае детям трехлетнего возраста не устраивали похорон, так как в этом возрасте ребенок не считался личностью.

Взросление человека определяется равными отрезками времени, для мужчины это циклы в 8 лет, а для женщины -7 лет. Так, молочные зубы у мальчика выпадают в 8 лет, в 16 лет он достигает зрелости, в возрасте 64 лет он теряет мужскую силу; у девочки в 7 лет выпадают молочные зубы, зрелости она достигает в 14 лет, в 49 она уже нефертильна т.д. Что касается духовного взросления, то здесь есть определенные возрастные рубежи, определенные Конфуцием:

«В 15 лет я обратил свои помыслы к учению, в 30 лет я имел прочную опору, в 40 лет у меня не осталось сомнений, в 50 лет я знал веление Небес, в 60 я настроил свой слух, в 70 лет следую своему сердцу, не нарушая правил»[25; 540].

Таким образом, личность в китайской культуре - это не индивид, а устроенная по образцу живого организма иерархическая структура, где высшей ценностью является движущая сила 生机 shēngjī и способность человека превозмогать себя 克己 kèjì, но не бесконечно, a согласно заложенным в организме потенциям роста. Здесь наиболее ярко прослеживается специфика китайской ментальности: доверие к творческой силе жизни и принятие судьбы, признание неизбежности и вездесущности иерархии и неверие в способность общества без твердой руки наладить свой быт.

Как уже упоминалось выше, для китайцев личность - это, прежде всего, «лицуо», воплощение общественной значимости человека. Китайская этика лица ставит акцент на взаимозависимости членов 
общества; каждый должен делать то, чего ожидает от него общество. Таким образом, личность включена в повседневность.

В нашем исследовании под повседневностью мы понимаем парадигму «человеческой жизни, рассматриваемой с точки зрения функций и ценностей, которые плотно заполняют жизнь личности, включая труд, быт, отдых» [3]. Повседневность постоянно воспроизводится как мощный пласт отношений и ценностей, непрерывная система человеческий забот. Нами повседневность рассматривается как область социальной реальности, в которой реализуется подходы к воспитанию идеальной личности.

Несмотря на то, что обе части Китая, и континентальная, и островная, успешно завершили процессы модернизации и включены в глобализированный мир, современному китайскому обществу попрежнему характерна традиционность. Как уже упоминалось выше, ощущение времени у китайцев особенное - они понимают его течение сверху вниз. Китайская архаика и классика, блистательные, высокие, образцовые эпохи «нависают» над модернизированным китайцем, определяя его настроение и линию поведения в повседневной жизни.

Всю историю развития китайской цивилизации ее носители сверялись с тем, как поступали древние, и это стало традицией. Таким образом, конфуцианство, буддизм и даосизм, нивелировав старания современных им школ и течений, образовали одно мощное поле учености и сакральных знаний. Современный китаец представляется нам стоящим в центре круга, разделенным на три сегмента, включающие вышеуказанные учения, и а зависимости от реальных жизненных обстоятельств обращается к каждому из них. Так, при череде неудач, он прибегает к буддийским средствам; стремясь сохранить молодость, занимается теми телесными и духовными практиками, которые дало ему даосское учение, а в быту, в социальной и семейной жизни, конечно же, согласовывает свои действия и принимает решения в рамках конфуцианских уложений.

По мнению Г.А. Ткаченко, «многие китайцы, будучи рутинно спрошенными о том, к какой религии они себя причисляют, отказы- 
вались отвечать, а предпочитали говорить только о пригодности той или иной религии в различных жизненных ситуациях» [38; 7]. Такое явление действительно имеет место и свидетельствует о том, что китайцы воспринимают 三教 sānjiā осинкретично, так как с разных точек зрения все три учения закладывают одну и ту же моральную установку.

Одним из главных постулатов конфуцианства является уважение к старикам, своим и чужим тоже. В «Книге о благодетели»мы находим:

慢人亲者,不敬其亲者也。Màn rén qīnzhe,bù jìng qī qīnzhe yě [1; 72].

Это изречение деятеля эпохи Цзинь Чэнь Тао можно истолковать как: «Не уважая чужих родителей, ты проявляешь неуважение к своим собственным». Однако в современном китайском быте можно встретить всякое. Так, каждый китаец поудобнее усадит своего старика, положит своими палочками кусочек повкуснее и вообще, будет проявлять гиперопеку 体贴 tĭtiē. Но в общественном транспорте в абсолютном большинстве случаев молодые не уступят место незнакомому пожилому человеку. Редки случаи, когда упавшему на улице приходят на помощь, так как существуют прецеденты наговора - оказавшего помощь обвиняют в причинении вреда здоровью и даже требуют компенсацию на лечение. Проблема стала настолько масштабной, что о тех гражданах, которые отваживаются оказать помощь незнакомцу, сообщают в информационных телепередачах. Очевидно, что боязнь потерять деньги и быть оклеветанным не дает китайцу действовать в заданном паттерне. Современность вносит свои коррективы в конфуцианское учение о подчинении и добродетели, но страдает все общество. Ведь еще Мо-цзы говорил:

人人亲其亲, 长其长, 而天下平。Rén rén qīn qī qīn, zhăng qī zhăng, ěr Tiānxià píng. Если каждый будет заботиться о стариках, и так будет из поколения в поколение, то мир воцарится в Поднебесной [1; 73].

Современные китайцы на этот счет имеют свое мнение - при такой большой популяции населения, нравственность и мораль не могут быть на высоте. В целях воспитания высоких моральных качеств 
в начальной школе на протяжении 5 лет дети изучают предмет под названием 品德 pĭndé, что исходя из содержания, можно перевести как «Основы этики и поведения в быту». Учебники включают ряд поучительных историй, предваряемых указаниями типа: «Переходи дорогу только в установленных местах» (сопровождается текстом об умном мальчике и замечательном транспортном гаджете - саморегулируемом светофоре, который можно переключить на зеленый свет для пешеходов, многократно нажав на специальную кнопку), или рассказ о зеленой травке, которая плачет, когда на нее наступают или сорят. Есть тексты, в которых рассказывается, почему не надо бросать мусор или плевать на пол. В них нет упоминания об уважении к чужому труду, это выпускается совершенно, так как уборщик (понимается с точки зрения функции) получает зарплату, а деньги надо отработать, а вот о том, что можно заразиться какой-нибудь болезнью, прописано подробно и красочно.

Конечно, введение такого предмета в школьный курс вызвано необходимостью работать над культурой быта и социального общения. Дело в том, что то, что мы подразумеваем под культурой (культурностью) не совсем понимаемо представителями китайской цивилизации. Культура у китайцев не рассматривается как сокровищница неких материальных и нематериальных ценностей, а она, прежде всего, есть 文化 wénhuà, то есть обращение к сакральной письменности, не более того. Над бытовой культурой еще предстоит работать, хотя объективности ради следует отметить, что в последние годы ситуация заметно улучшилась. В свете того, что Китай открыт внешнему миру как никогда прежде, возникают неловкие ситуации, когда о них судят по бытовой культурности, по шуму и громких разговорам, неумению, с точки зрения западного человека, вести себя в общественных местах, выкидываемому везде и всюду мусоре и т.п. Такой неприглядный имидж не совсем по душе китайцам, поэтому образование ведется и вертикально - в младшем, среднем и старшем звене национальной школы, и горизонтально - на многочисленных плакатах, расклеенных на заборах и стенах зданий. 
Нередко в учебники 《品德》 вносят тексты из советской и русской детской литературы. Таким образом, прививается особый образ поведения, который не входит в противоречие с принятыми китайскими нормами, но способен сформировать космополитический подход. Популярны рассказы Мамина-Сибиряка, Гарина-Михайловского, Максима Горького и т.д.

Принимая во внимание стремление китайцев к бережливости, в учебник включены и поучительные истории о том, что надо беречь школьную мебель (получишь поощрение от учителя) или сортировать мусор правильно (сдашь пластиковые бутылочки от молока и заработаешь 5 юаней) [59; 43].

Если в классическом Китае отношение к наставнику всегда было трепетным и внимательным, хотя бы потому, что содержание учителя с семьей считалось делом дорогим, то Китай XX века познал ужас и лишения, которые принесла китайскому обществу культурная революция. Это десятилетие отбросило новый Китай на многие годы назад: целое поколение не получило должного образования, а значит, возможности занять достойное место в жизни; покалеченные судьбы людей, попавших в исправительные учреждения или молодых интеллигентов, не имевших возможности проживать в родных местах, попавших под политику «отправления в деревню» 下乡 xiàxiāng и дальнейшего трудового перевоспитания. Но самое ужасное, что могло произойти - это физическое истребление творческой интеллигенции и педагогов, которое произошло в то время. Китай потерял множество писателей, ученых, работников искусства, учителей и преподавателей, которые были вынуждены не работать, а приходить на работу, где их ежедневно заставляли писать самообличительные дацзыљбао, а потом и попросту избивали.

Престиж учителя был утрачен, как и покалечено целое поколение современных китайцев среднего возраста. В связи с этим в учебники «品德》 внесены рассказы, о том, что учительский труд и сложен, и порой неблагодарен. Детей призывают «слушать учителя», «не перебивать его», «подсказать учителю, если твой товарищ не следует его указаниям» и т.п. [59; 41]. 
Конечно, работа по укреплению престижа профессии учителя ведется. Учитывая ту конкурентную образовательную борьбу, в которую включены молодые китайцы, чтобы получить больше знаний и выше оценку на экзамене, дабы оправдать чаяния семьи, тот стресс, в котором они проводят до 10 часов в день в школах и институтах, то становится понятным, что порою объектом для вымещения своих неудач, а порою и насмешек, становятся все те же учителя. Такими роликами полон китайский интранет. Вот здесь и находится место для работы медиаторам, которые призваны свести такие конфликты к компромиссу.

В современном китайском обществе стремятся поднять уровень моральных качеств, так называемых 素质 sùzhì. Складывается узнаваемая ситуация - теоретически все знают, что такое моральные качества, но никто не знает, как повысить их уровень. Все сводится к тому, что китаец или китаянка в целях продемонстрировать высокие 素 质 sùzhì пытаются просто не оскандалиться, не ругаться, не повышать голос в конфликтной ситуации, что говорит о том, что человек действительно понимает мораль строго в рамках бытовой ситуации. Так, в завязывающемся громком разговоре тот, кто считает себя более воспитанным, произносит фразу:

你的素质那么低么? Nĩde sùzhì nà mè $\mathrm{dī}$ ma?

«У вас настолько низкие моральные качества?»

Таким образом, мы можем наблюдать, как китайцы осознают специфику своего поведения и мышления, соотнося традиционные представления и те, которые рекомендует им мировая глобализированная культура, тем более, что в последние годы китайские граждане получили большую мобильность и невиданный ранее шанс познавать мир не только виртуально, но и в туристической и образовательной поездке. 


\section{2 Идеал конфуцианской личности и современность}

Говоря о вызовах, которые получают все традиционные общества в современном мире, мы указали на то, что проверку на прочность проходят прежде всего базовые ценности того или иного сообщества. Там, где глобализационные вызовы принимаются и получают обратную реакцию обращения к культурным корням (в лучшем случае) или нетерпимость и отрицание всего чуждого (в виде агрессии в худшем случае), можно говорить, что ядро культуры сохраняется. Так происходит в бо̀льшей части континентального Китая. Там, где ценности китайской культуры исторически насаждаются (например, в «горячей точке» Китая - Тибете) или же на территориях, исконно находившимися за пределами китайской ойкумены и получивших опыт так называемого мультикультурного плавильного котла (Тайвань, Гонконг, Макао), происходят процессы присягания на верность ценностям традиционной китайской культуры в протест на то, как эти ценности понимаются в коммунистическом Китае.

Итак, быстрый прирост населения КНР, который произошел в годы культурной революции, политика ограничения рождаемости и некоторые другие процессы стали причиной возникновения целого ряда широко известных проблем: стремительное старение населения, гендерный перекос в 50 млн человек в пользу мужчин, повышение конкурентной борьбы за место под солнцем среди молодежи, и как следствие - отчуждение и полная материализация отношений. Возникает парадокс: некогда гармоничное сочетание следования высокой морали и умеренным стремлением к достижению материального благополучия стало разрушаться под напором абсолютного поклонения материальному.

Современная китайская молодежь и люди средних лет самой главной ценностью считают материальное состояние и приличное положение в обществе, они тратят целую жизнь для достижения этих благ. Ритм жизни современного китайца увеличился (как следствие включенности в процессы глобализации), семейные связи рвутся (так как члены семьи уже не всегда работают сообща, а порою по полгода живут в разных провинциях, зарабатывая 外工 wàigōng «на стороне»). 
Для того, чтобы создать семью, обе стороны должны постараться семья жениха покупает квартиру и машину, семья невесты - делает ремонт и несет часть расходов по организации нескольких свадебных церемоний - в городе или селе родителей жениха, то же в местности проживания родителей невесты, по месту работы обоих и т.д.

Надежды семьи на продолжение рода также напрямую связаны с достижением материального благополучия. Даже маленькие дети в Китае включены в процесс конкуренции: сначала - кто лучше говорит, знает больше идиом, умеет быстро посчитать (в возрасте 3-5 лет), потом нагрузка увеличивается, и кроме школы китаец должен успевать на занятия по каллиграфии, танцам, музыке, рисунку тушью и т.д. Затем подключаются успешные хорошо оплачиваемые учителя 名师 míngshī, стараниями которых абитуриент получает высокие баллы и поступает в престижный университет. Времени для размышлений или духовного роста просто нет, так как объем двенадцатилетней школьной программы велик. Если современный китаец знает что-то о культуре, то, скорее всего, из учебных текстов или телевизионных передач, в которых также непременно будет сделан акцент не только на ценности предмета искусства, но и на его стоимости. Высокие ожидания родителей влекут за собой существенный процент разочарований от собственных достижений и целую волну суицидов среди студентов. Так, одной из черных шуток китайской молодежи является неофициальное название одного из государственных праздников Дня молодежи, которое вместо 五四 wŭsì «Четвертое мая» произносится как 我要死 wŏ yào š̆ «помереть охота».

Тщательное культивированное стремление к обогащению привело китайцев в нравственный тупик, выход из которого, как водится, надо поискать в блистательном и героическом прошлом нации и народа. Однако в век высоких технологий и информационных войн старомодно обращаться к героям эпических сказаний, значит, приходится искать героев наших дней.

Возникновение типа модернизированного китайца вполне объяснимо с точки зрения того, что социальная жизнь индивида очень 
насыщена, а стремление к повышению уровня жизни способствует появлению качеств, которые не были присущи традиционному китайцу. Так, прагматизм межличностных отношений, который проявился особенно ярко в последние три десятилетия, с началом политики реформ и открытости Китая миру, постепенно отодвигает на дальний план такие базовые понятия китайской культуры, как человеколюбие и гуманность; отношения все больше приобретают меркантилизированный характер [51;37].

Необходимо отметить, что успешных с точки зрения китайцев людей в КНР и на территории Большого Китая проживают немало. Все они достигли материального благополучия и заметного положения в обществе. Так, особенно ценятся те, кто сумел сделать имя на традиционно почитаемых китайских занятиях - занятии родным языком и торговле. К этому числу относятся, например, самый зарабатывающий на сегодняшний день китайский писатель - Го Цзинмин, или выдающийся мастер песенного сказа Северо-Востока Китая Чжао Бэньшань [53; 55].Таких примеров много, общество ожидает от них не только зрелища, но и участия в благотворительности, особенно когда происходят действительно масштабные катастрофы, наводнения, землетрясения и т.п.

Сбор средств в пользу пострадавших проходит на поражающих по своим масштабам и красочности концертах с участием звезд и общественно значимых людей. Средства собираются публично, с оглашением суммы пожертвований. Так, в мае 2008 года, когда успешный китайский баскетболист Яо Мин одним из первых внес 200 тысяч юаней в фонд помощи пострадавшим от разрушительного землетрясения в Вэньчуани, об этом знали все, даже младшие школьники, которые, к слову, участвовали в благотворительном мероприятии, покупая по двойной цене бутылку воды с тем, чтобы помочь пострадавшим [58; 12].

Категория бескорыстной помощи - вот то, что потеряно в современном китайском обществе и ощущается самими китайцами очень остро. Но примеры успешных людей, охотно жертвующих частью своих доходов в общие сборы для действительно нуждающихся, 
пострадавших от воли Небес, наверное, не так ярки и актуальны, как незыблемые образцы времен революционной романтики и национального подъема. Таких имен, как Су Нин, Цзя Лидань, Лэй Фэн и других товарищей народных, очень много. Невероятное количество общеобразовательных школ, крупных компаний и магазинов носят эти славные имена. То, что отличает их от нуворишей - это преданность Родине и бескорыстное служение китайскому народу.

Попытки модернизации традиционных ценностей и их приложение к современным ситуациям активно предпринимались созидателями нового Китая. В этом плане интересно проследить формирование и эволюцию образов народных героев, представляющих собой выходцев из класса неимущих, простых людей, едва ли получивших начальное образование, живущих идеей всеобщего равенства, жертвующих всем во благо общества в целом.

Возникновение целой галереи портретов революционных героев обусловлено необходимостью создания чувства сопричастности для огромных масс населения и создания противовеса культу личности Мао Цзэдуна, как человека, несомненно, выдающегося, о чем свидетельствуют многочисленные эпитеты, бытовавшие во всех без исключения поэтических произведениях периода Культурной революции по нарастающей, от «Мао как Солнце» к «Солнце как Мао» [см. Приложение А].

Процесс героизации боевых товарищей, начиная с 50-х годов $\mathrm{XX}$ века, характеризуется акцентированием на великие подвиги (военные и трудовые), совершенные простыми китайскими бойцами во имя свободы и созидания Нового Китая. Это отражено в истории китайского агитационного плаката. Так, в 1964 году была издана серия под названием «Наш герой Хуан Цзигуан», посвященный подвигу, совершенному товарищем Хуан Цзигуаном (1930-1952) во время Корейской войны [см. Приложение Б]. 19 октября 1952 года он пал смертью храбрых, бросившись на амбразуру вражеского дота.

Кроме индивидуальных плакатов народных героев, выпущена серия, посвященная собирательному образу воина НОАК, который изображался как непримиримый боец за воссоединение Китая «Осво- 
бодим Тайвань», верный маоист с цитатником Мао в руке «Вперед революционным курсом», бдительный солдат, наблюдающий за передвижением советских войск у границ КНР [см. Приложение Б].

Особенностью этого периода можно назвать то, что все герои совершали подвиг во имя идей Мао Цзэдуна и были беззаветно преданы делу маоизма. Плакатные образы героев позволяли поддерживать необходимый эмоциональный накал и обеспечивали известную степень революционной романтики тех лет.

Кроме популяризации деятельности воинов-маоистов, борющихся с явным врагом (Япония времен интервенции в Китай и СССР периода военных действий на о. Даманском), часть плакатов посвящена борьбе с мировым злом (фашизм, американская агрессия в сопредельные с Китаем страны); находится место и для воспевания образа труженика, который «горит на производстве», агитационный материал «Все на производство!» [см. Приложение Б].

Цель агитационных плакатов этой направленности очевидна создать правильную политическую установку у народных масс, включенных в процессы Большого Скачка (1958-1960) и Культурной революции (1966-1976), ориентируя наиболее идейных на работу внутри огромного социума в ритме «быстрее, больше, интенсивнее». Как известно, все чаще страдало не только качество производимых товаров, но и ломались человеческие судьбы: как водится, находились и те, кто не поспевал в ногу со временем, и их обвиняли в протекционизме и антиреволюционной подрывной деятельности.

Личность учителя значима для китайцев на протяжении всей истории развития этого этноса. В рассматриваемый период, в силу того, что нарождающаяся новизна бытия периода Большого Скачка и Культурной революции в принципе не могла быть соотнесена со старыми идеалами и их трансляторами - учеными, учителями, интеллигенцией, возникла необходимость в культе новых учителей: китайцы испытывают потребность в лидере, у которого можно поучиться.

Агитационный плакат представлен достаточно обширно, часть из них можно обозначить в парадигме «Учись у...». Наиболее яркие и убедительные в этой серии - плакаты с Председателем Мао. Великий 
Кормчий указывает правильный путь революционным депутатам, народным ходокам, идейной молодежи, а также выступает в роли неоспоримого лидера в глазах мирового пролетариата, борющегося за свои права (плакат «Председатель Мао - путеводная звезда мировой революции»). Ближе к концу Культурной революции наблюдается тенденция обращения к идеалам Учителя, стоящего близко к принципам Сунь Ятсена, но не ангажированного маоистскими идеями. В рассматриваемой серии «Учись У..» появляются плакаты «Учись революционном духу у Лу Синя» [см. Приложение Б].

При всей наглядной убедительности агитационного материала становилось все понятнее, что идеи маоизма, усвоенные молодым поколением тех лет, должны были получать возможность воплощения в реальную жизнь реальными людьми. Требовался уже не подвиг, а поступок. Так возникает плакатный образ Лэй Фэна.

Несмотря на то, что поначалу это всего лишь один из многочисленных героизированных персонажей того времени (Су Нин, Цзя Лидань и другие), он оказался наиболее популярным, эффективным и долговечным. Секрет заключается в том, что Лэй Фэн, простой боец, в силу трагических жизненных обстоятельств погиб до начала Культурной революции, времени драматичного и памятного нескольким поколениям китайцев. Если у значительной части китайского населения, верно служившего делу Мао Цзэдуна, остается убежденность в правильности каждого шага, то другая часть населения, пострадавшая от деятельности маоистов морально и физически, считает Культурную революцию не только официально признанной ошибкой, но и трагедией всекитайского масштаба.

Люди среднего и молодого возраста должны быть правильно сориентированы в данной ситуации, а значит, возникает необходимость в создании некого идеала - простого китайца, борца за интересы всего народа, социально активного, сочетающего в себе гармоничное соотношение традиционных ценностей, реализующего себя в современной жизни. Таков Лэй Фэн - верный маоист, не причинивший никому вреда, в силу того, что жизнь его безвременно оборвалась до начала преступлений, совершенных хунвэйбинами. 
Образ верного маоиста, молодого бойца НОАК Лэй Чжэнсина, больше известного как товарищ Лэй Фэн (1940-1962), весьма популярен в КНР(см. Приложение В). Его жизнеописание актуально еще и потому, что оно выполнено в духе конфуцианских образцов высокой китайской древности, несмотря на то, что со дня его смерти прошло немногим более 56 лет. Имя Лэй Фэна канонизировано в отдельно взятом Шэньянском военном округе, в воинской части, где он служил при жизни, культивируется учение нравственности в «духе Лэй Фэна».

То, что подкупает в истории жизни этого молодого китайского сироты - это вера, в то, что если человек отдает всего себя Родине, Родина его не забудет. Лэй Фэн прожил очень короткую, но яркую жизнь. Родился 18 декабря 1940 г. в провинции Хунань, в 7 лет остался круглым сиротой. Как позже он напишет в своих пробных эссе: «Как сирота стал верным бойцом товарища Мао», или «Я рано лишился родителей, но партия заменила мне мать» [50; 37].

Лэй Фэну выдалось жить в те самые годы революционного подъема, и фанатизм, с которым он увлекся делом Мао, соотносима с конфуцианской категорией верности 忠 zhōng и актуализирована к требованиям времени.

Под крайним проявлением верности Лэй Фэна надо понимать, прежде всего, преданность курсу КПК и Родине. Для целого поколения маоистов (ныне граждан КНР преклонного возраста), эти два понятия были нераздельны. Вот как товарищ Лэй Фэн писал в своем эсce: «После освобождения Китая я обрел семью, это КПК!» [50; 39].

Не получивший какого-либо образования, молодой боец был увлечен идеями национального строительства, а его преданность делу Мао Цзэдуна соответствовала духу революционного времени. Верность, с которой молодые маоисты относились к делу революции, соответствует категории преданности чжун 忠, о которой много написано в конфуцианских постулатах. Поколение Лэй Фэна в принципе не разграничивало верность делу КПК и чувство любви к Родине. Как указывалось выше, онфуцианское понятие доброты шань 善 также подразумевает способность к самопожертвованию. 
Следование идеям Мао подразумевало умение жертвовать и большим, и малым. Так, в своем интервью политрук Шэньянского военного округа Гао Цзяньго упоминает: «В августе 1960 г в составе группы новобранцев Лэй Фэн участвовал в ликвидации наводнения на водохранилище, где бойцам пришлось в течение 7 суток сдерживать напор воды собственными телами, и он был не один такой, их было целое поколение» [50;40].

Совсем в духе Лу Ю, поэта эпохи Южной Сун:

位卑未敢忘忧国。Wèibēiwèigănwàngyōuguó.

И даже занимая незначительное место в Поднебесной, вноси свой клад в ее процветание $[1 ; 5]$.

Жертвенность была одной из сильных черт характера Лэй Фэна: весной 1958 года он передает 20 юаней для покупки комсомольского трактора, а через два года он переводит свои собственные средства 200 юаней в пользу жертвам наводнения в Фушуне. Кроме того, они были вынуждены делиться с жителями пайком и носильными вещами. Лэй Фэн отдал пострадавшим две пары носков из трех, положенных ему в месяц. Работа по 16 часов в сутки в кирзовых сапогах была выматывающей, и бойцы не имели возможности получать новое обмундирование, однако это не стало препятствием для товарища Лэя [50; 40].

Как говорится в «Летописи Чуньцю»:

治国之道, 必先富民。Zhì guó zhī dào, bì xiān fù mín.

Чтобы процветало Срединное государство, сначала должен благоденствовать ее народ $[1 ; 53]$.

Шагая в ногу со временем, Лэй Фэн всегда носит при себе цитатник Мао, а свои мысли, посвященные Великому Кормчему, он пишет в своем дневнике, опубликованном позже в передовице Шэньянского военного округа.

Вся жизнь Лэй Фэна - это образец жизни простого человека, умеющего не только находить радость в незатейливых развлечениях (игра на аккордеоне в группе самодеятельности), стремление быть полезным обществу (статья «Я научился водить трактор!»), но и та 
жертвенность собой, которая культивировалась столетиями, и не требовала свершения отважных подвигов.

По мнению Гао Цзяньго, «учение в духе Лэй Фэна», являющееся базовой идеологической подготовкой в Шэньянском военном округе, имеет огромное количество последователей, для которых общественная жизнь в стиле Лэй Фэна становится жизненным кредо. Первыми ласточками стали бывшие сослуживцы Лэй Фэна, а потом и целые поколения демобилизованных бойцов предлагали свою бескорыстную помощь при ликвидации последствий пожаров и наводнений [50].

Такое самоотверженное поведение не кажется Гао Цзяньго выходящим за рамки нормы, кроме того, он указывает на тот факт, что образ Лэй Фэна стал своеобразным брендом, за которым вышла целая плеяда таких жекак он, бескорыстных воинов своего народа.К слову, в воинской части, где служил Лэй Фэн, существует музей его имени, там собраны весь небогатый жизненный багаж бойца, а грузовик, которым управлял его боевой товарищ в момент несчастного случая, повлекшего смерть героя, тщательно выкрашен и ухожен.

Товарищ Гао усматривает популярность учения в духе Лэй Фэна в его соответствии традиционным китайским ценностям, в частности конфуцианским постулатам об идеальном человеке (долг, верность, ритуал и т.д.). Поэтому оно имеет огромное количество последователей среди бывших служащих и даже популяризуется среди гражданского населения [50; 41].

Среди последователей Лэй Фэна есть те бойцы, которые попали в Шэньянский военный округ для того, чтобы получить опыт аскезы бытия в современном китайском понимании. Так, Гао Цзяньго упоминает о сыне весьма состоятельного человека, который по приезде на службу проявлял скверный характер и даже буржуазные замашки, пытаясь нанять своих сослуживцев для того, чтобы они стирали за ним белье. Не прошло и года, как с малым Чжэном произошли разительные перемены: он увлекся дневниками Лэй Фэна, проникся благотворительной деятельностью, пожертвовал 9800 юаней в пользу детей из неимущих семей, оплатив их обучение в начальной школе. 
Кроме того, если в начале службы он не прислушивался ни к чьему мнению, то перед демобилизацией частенько повторял знаменитую фразу:

三人行, 必有我师也。Sān rén xíng bì yŏu wŏ shī yě.

Идут трое, среди них может быть мой учитель [1;98]

И если Конфуций призывал учиться даже у незнакомых, подразумевая, что «море знаний безбрежно, но горечь становится лодкой», то современное китайское общество подспудно подталкивает молодежь учиться у тех, кто более успешен, одновременно акцентируя внимание на подвижничестве воистину народных героев, радевших на благо общества, и вот, в каждой овощной лавке или небольшой парикмахерской мы видим призывы бегущей лэд-строкой: «向雷锋学 习!» Xiàng LéiFēng xuéxí «Учитесь у Лэй Фэна!»

Таким образом, столкнувшись с необходимостью идти на компромисс между преобладающей потребительской позицией большинства и требованиями морали, современное китайское общество все же пытается задать правильное, с точки зрения традиционных взглядов направление - добродетель возможна лишь тогда, когда общие интересы ставятся выше личностных. Завершив основные задачи по модернизации, китайские власти пытаются найти способ осовременить базовые ценности, упирая на то, что принцип демократического централизма, выражающийся в подчинении мнения меньшинства большинству, не является чем-то новым или привнесенным извне китайской культуры. Обращаясь к мудрости всезнающей китайской традиции, они заставляют молодое поколение постичь одну простую, но привлекательную истину:

天下非一人之天下,乃天下之天下也。

Tiānxià fêi yì rén Tiānxià, năi Tiānxià zhī Tiānxià yě.

Поднебесная не принадлежит одному человеку, она принадлежит всем $[1 ; 3]$.

Современное китайское общество подспудно подталкивает молодежь учиться у тех, кто более успешен материально, а эффективная подача этого образа дает возможность объединить чаяния сразу не- 
скольких поколений китайцев. С одной стороны акцентируя внимание на авторитет и актуальность конфуцианских принципов - гуманности и служению обществу, с другой стороны, на гармоничную включенность героев периода Большого Скачка и Культурной революции в подвижничестве на благо общества, идеализированный образ Лэй Фэна являет собой результат долгих исканий и успешных попыток конструирования национального самосознания.

Таким образом, на разных уровнях китайского общества происходит насаждение нравственного идеала современной личности, воспитанной в духе конфуцианских традиций, успешно адаптирующейся к современным экономическим, социальным и иным требованиям китайского социума, находит свое подтверждение. Анализ исследованного материала на китайском языке дает возможность утверждать, что китайцам, во-первых, удается актуализировать традиционные конфуцианские ценности и убрать оковы догмы, благодаря современной интерпретации. Во-вторых, создание и репрезентация нравственного идеала происходит на всех уровнях образования и социализации личности, начиная от учебников младшей школы до повседневного агитационного материала, который транслируется в СМИ и на улицах китайских деревень и городов.

\section{3 Проблемы нравственного воспитания молодежи КНР}

Всю историю развития китайского общества ядром традиционной китайской цивилизации была не идеология, а «духовная работа $u$ не-делающая деятельность мудрого, в которой сходятся сознание и действие» [25; 611]. Мир китайской традиции всегда сопряжен с присутствием сердца, как отражением разума и тела одновременно. Это привело к тому, что появился особый культурный тип, который задан не столько познанию, сколько почти бессознательному усвоению в способе воспитания, чувствования, мышления. Этот феномен мы можем подкрепить примером в образовательных методиках: ученик не просто должен выучить формулы и правила, но познать тип поведения учителя и накапливать знания, а успехи ученика оцениваются степенью приближения к учителю. Так, в каждом классе есть староста, называемый 
老师的帮手 lăoshīde bāngshŏu, а после написания контрольной работы учителем всегда отмечаются успехи первых пяти успешных учеников. Такие методики имеют и обратное действие: возникает привычка налаживать связи, ученики могут быть скрытны и т.п.

В XX веке Китай испытал серьезные изменения: революционное движение, положившее конец многотысячелетнему институту императорской власти, гражданская война, потрясения культурной революции и многое другое.Преобразования в китайском обществе, тем не менее, привели к парадоксальным результатам: пропаганда конфуцианских ценностей в Китайской Республике Тайвань не послужила препятствием для быстрой модернизации и демократизации общества. Тайвань вообще стал своего рода площадкой, где происходят значимые процессы сплавления сразу нескольких культур: тайваньской аборигенной, исконно китайской (в противовес «упрощенной» континентальной китайской), европейской (со времен деятельности Ост-Индской компании), японской (50 лет правления начиная с воцарения эпохи Мэйизи до 1945 г.), американской (с 1945 г. и по нынешний день) [5].

В 1976 г. тайваньский писатель Бай Сяньюн зафиксировал появление типа «странствующего китайца», обреченного на духовную эмиграцию. Это свидетельствует о том, что идеологические системы $\mathrm{XX}$ века потерпели фиаско. Американские технологии искусственного построения национальной идентичности и моделирования цветных революций эффективны для построения нации, но вряд ли имеют решающее значение для китайской культуры. Дело в том, что движущие силы Китая кроются в формах общественной практики, связанных с традиционной культурой и современностью. В критические периоды китайцы предпочитают обратиться к прошлому, ведь именно возвращение к корням дает новый положительный заряд к движению вперед. Конечно, ностальгия по идеальным героям порою неизбежна, вот как точно выразил настроение танский поэт Чэнь Цзыан:

前不见古人 qián bù jiàn gŭ rén

后不见来者 hòu bù jiàn láizhe

念天地之悠悠 niàn tiān dì zhī yōu yōu 
独唱然而涕下 dú chàng rán ér tì xià

Не вижу древних я следов,

И позади достойных нет,

Оплакиваю судьбы Поднебесной,

И слез моих никто не видит след. («Песнь на пагоде Ючжоу») $[57 ; 19]$

Традиции и новации, существующие в обеих частях китайского сообщества(и в континентальном китайском, и в островном тайваньском), на первый взгляд могут показаться слишком разительными, остроту их противодействия мы можем видеть всюду в мире, где принимаются вызовы глобализации. Однако весь Большой Китай являет собой яркий пример того, как ценности традиционной цивилизации легко уживаются со всем тем, что породила постиндустриальная эпоха - современной техникой, передовыми технологиями, новейшими системами управления. Китайский образ жизни с его бесконфликтным поведением, преданностью семье и политической индифферентностью легко применим новым условиям действительности.

Модернизированный тип китайца, порою абсолютно чуждый фундаментальным ценностям китайской традиции встречается всюду: и в КНР и в Большом Китае. «Новый китаец» готов к соперничеству и риску, он более требователен к бытовым условиям, и не считает скромность благодатью. Постулат Мо-цзы кажется неактуальным, или принимается к сведению с одной из лицемерных масок, включенных в категорию лица:

辞让之心,礼之端也。Cí ràngzhī xīn, ľ̃ zhī duānyě.

Начало добродетели в скромном сердце $[1 ; 218]$

Тем не менее, современный китаец все же не похож на европейца, потому что предпочитает жить компактно: поселяясь по всему свету, китайцы основывают чайна-тауны, представляющие собой особую модель «мира в мире», потому что:

众志成城,众口铄金。Zhòng zhì chéng chéng, zhòngkŏushuò jīn.

Воля народная города строит, металл плавит $[1 ; 56]$ 
Современный китаец особым образом сочетает в себе сплав китайского и западного знания, дающий жизненным ценностям китайцев новое качество жизни. Так, в детских садах КНР нашла успешное применение методика Монтессори, при которой от ребенка требуют запоминания, а не понимания. На первый взгляд, факт такого заимствования вызывает удивление, но если задуматься, то именно методика для китайцев не нова: заучивание наизусть классических текстов, на начальном этапе без объяснения учителя, широко применялась в старом Китае.

С другой стороны, и в России, и на Западе в последние десятилетия наметилась тенденция увлечения китайскими духовными и телесными практиками. Многие считают необыкновенно привлекательными занятиями разного рода медиативной практики или школ боевых искусств. Секрет такой популярности, с нашей точки зрения, заключается в том, что в постиндустриальную эпоху становится очень важным жить в согласии не только с соседом, но и, прежде всего, в гармонии с собой.

В свете этого становятся не только актуальны, но и популярны конфуцианские истины, например, в изложении Хань Юя:

业精于勤,荒于嬉,行成于思,毁于随。

Yè jīng yú qín,huāng yú xī, xíng chéng yúsī,huî yú suí $[1 ; 126]$

Успех занятий кроется в старании, а неудача прячется в праздности, путь к свершениям в помыслах таится, но в безразличии крах затаён.

Современное понимание праздности имеет принципиальное отличие от того, как оно осознавалось в классическом Китае. Праздная жизнь интеллектуала включала целый ряд занятий, требовавших огромного количества времени для себя. Так, игра в шашки, любование природой или изящной антикварной вещицей, сложение стихов, которые исполнялись подругой поэта под звуки цитры и т.д., составляло очень большой пласт жизни человека культуры вэньжэнь.

Успех для интеллигента того времени заключался в строгом следовании ритуалу, соответствии поведению благородного мужа; он преследовал вполне конкретную цель - получить искомую ученую 
степень на дворцовом экзамене, и, если повезет, то и ощутимую прибавку в виде жалования, материальных благ и почета со стороны проживающих в подконтрольном новоиспеченному чиновнику уезде или волости.

Экзамен представлял собой сложное испытание, заключавшееся в написании восьмичленного сочинения на тему, заданную императором и в том стихотворном размере, который указывал Сын Неба. Количество иероглифов было точно определено. Темами служили эпизоды из древней истории или деяния великих предков.

Экзаменуемый находился в отведенном ему помещении дворца в течение трех дней и питался тем, что принес собой. Общение с внешним миром было ограничено. «Войти в драконовы ворота», то есть успешно сдать экзамен на чиновничью должность, было делом непростым, ведь оно было сопряжено с победой в двух важных для китайца позициях - показать мастерское владение родным языком и отечественной историей, и преуспеть, заняв должность в имперском управленческом аппарате.

Успех приходил не всегда, порою претенденты годами пытались сдать злополучный экзамен, но никак не могли этого сделать. Так, знаменитый мастер рассказов о лисах-оборотнях Пу Сунлин несколько десятков лет терпел поражение на экзаменах, хотя его экзаменаторы зачитывались написанные им «Рассказы Ляо Чжая о необычайном». Несмотря на то, что это произведение находилось под негласным запретом (местные культы лис-оборотней и тигров-некрофагов осуждались китайской традицией, так как затрагивали мистическую, даосскую сторону бытия), во дворце имела хождение книга Ляо Чжая, написанная тушью на шелке. Она была обнаружена уже после падения Цинской династии и, к сожалению, была утрачена при захвате дворца [33] .

Получение искомой степени тоже не всегда гарантировало материальный успех: должность могли не давать годами, так как она была занята, либо претендент отправлялся в своеобразную «ссылку» на самый край китайской ойкумены. Это был крайне нежелательный исход, так как для китайцев удаление от центра имеет значение отрыва от Родины. Популярные ныне острова Хайнань и Тайвань в старом Ки- 
тае представляли собой не что иное, как место ссылки преступников или обитель тех, кто спасался от долговой ямы.

Подготовка к экзамену предполагала изучение классических канонов, входивших в «Малое учение» и в «Большое учение». Они представляли собой классические конфуцианские тексты, включавшее в себя небольшой отрывок из источника, скажем «尚书 », «Shàngshū»(«Книги истории») и объемного комментария к нему. Современная наука располагает теми текстами, которые прошли переработку неоконфуцианцами, например, школы Чжу Си, жившего в XII веке. Мао Цзэдун в своих мемуарах вспоминает, что «учитель заставлял наизусть учить нас древние тексты, и только когда мне исполнилось 16, он сказал, что теперь будет толковать» [46]. Таким образом, методика изучения классических текстов родного языка наизусть является поверенной годами и действенной, поэтому она применяется и в современной школе. Классические тексты преподаются с обязательным комментарием, точно так же, как это сделано в исследуемом нами источнике.

Подготовка к сдаче экзамена формировала образ жизни китайского ученого. Так как написание сочинения требовало и знание предмета, и умение написать текст в стихах, и особого почерка письма, все это породило прекрасную традицию написания текста на особой бумаге, (в наше время это сорт 悬纸 xuán zhî), специально подобранными кистями, в шести категориях 六书 liù shū. Китайский интеллигент часто писал классические пейзажи, на которых обязательно присутствовали: вода (символ космического женского начала), горы (космическое мужское начало), растительность в каком-либо виде - осенняя сообщала о конечности бытия, летняя, наоборот, о цветении жизни.

Пейзаж является не просто картиной, но особым местом духовного общения с предками или деятелями китайской традиции. Каждый художник оставлял пустое место на картине, для того, чтобы наблюдающий мог вообразить себя на картине и «встретиться» с творцом, например, мастером монохромной живописи и блестящим поэтом Ван Вэем. 
Такая подготовка предполагала формирование особого ощущения причастности к символическому полю носителей китайской культуры, полунамеку, радости от узнавания спрятанных секретов и ликование от возможности их разгадать. Стало быть, и занятия китайского интеллигента - рисунок тушью, стихотворная надпись в определенном стиле письма и т.д. не только создало сильный культурный паттерн поведения, но и заставляло не обладающих этими знаниями не только не считать эти занятия праздными, но и благоговеть перед ними.

Рисунок тушью позволял сохранять не только полутона, но и полунамеки, наверное, в этом и заключается его притягательность, тем более что традиционная китайская живопись не пользовалась масляными красками и прибегала к пенктонике цвета, в том виде, в котором ее определили древние.

Особенность китайской культурной традиции как раз таки заключается в ее жизнеспособности. Современность, диктующая нам стремительный образ жизни, никак не влияет на традиционно любимые (и необходимые, подразумевающиеся как необходимые) занятия каллиграфией и живописью в стиле 国画 guóhuà, которая также содержит в себе множество секретов символов: государственного цветка пиона, нежной орхидеи, персика - символа долголетия и т.п. В китайскую повседневность включены все понятия нравственных категорий: ритуал, долг, сыновняя почтительность, верность, преданность Родине. Они культивируются в семье јіā 家, которая восходитк обществуdàjī̄ 大家, и к государственности guójiā 国家. Привитие моральных качеств осуществляется не только в общеобразовательных учреждениях разного уровня, но и посредством телевизионных и радиопередач, а также популяризации бескорыстной помощи в духе народного героя Лэй Фэна как среди населения (посредством наглядной рекламы), так ив Шэньянском военном округе. Процессы глобализации привели к тому, что традиџионный тип китайца поменялся на типмодернизированного китайца, сочетающего в себе в разной степени почитание нравственных идеалов прошлого и прагматичный подход к жизни, способности конкурировать, возможности занимать активную жизненную позицию. 


\section{Глава 3. Китайский мир в эпоху глобализации}

\section{1. Опыт семейного воспитания в Большом Китае}

Воспитание человека всегда ориентировано на заданную модель поведения, принятую в обществе. Исследователи отмечают необходимость отличать это явление от реального поведения человека в повседневной жизни. Под моделью поведения подразумевается общепризнанный стандарт, сложившийся исторически, заключающий в себе оценочный смысл. В зависимости от типа культуры может возникать явление субъективной ориентированности на норму: в коллективных культурах одобрение получает поведение в заданных рамках, в индивидуальных - стремление к альтернативному, возможность проявления оригинальности. В случае с китайской культурой, являющейся базовой как для жителей континентального Китая, так и для островного Тайваня, нормой является следование конфуцианским уложениям, актуализированным к современным условиям. Тем не менее, система воспитания в тайваньском обществе обнаруживает новые тенденции к проявлению себя как части мультикультурного пространства, и, вместе с тем, демонстрированию собственной оригинальности в рамках локализации глобальной культуры.

Вопрос о принципах конфуцианского воспитания достаточно хорошо освещен в научной литературе с разных точек зрения, в том числе и в свете популяризации конфуцианской личности в странах, территориально примыкающих к китайской ойкумене и воспринявших конфуцианство как основу государственного уложения. Небезынтересно проследить воспитательный опыт китайских родителей из континентального Китая, Тайваня и США, имеющих одинаковые ценностные установки, вследствие принадлежности к китайской культуре, но проживающих в странах с разным социальнополитическим строем.

В КНР в последнее время стали появляться серии книг, содержащих советы клинических психологов, работающих с детьми дошкольного и школьного возраста. Полученное профессиональное образование позволяет авторам применять на практике принципы за- 
падных методик, к примеру, систему Монтессори с классическим китайским подходом заучивания наизусть материала из китайской литературы, математики и смежных областей знаний. Книги о воспитании содержат отсылки к прецедентным именам и событиям китайской истории, в которой всегда найдется достойный пример для подражания. Кроме того, в них много говорится о традиционных китайских ценностях (подчинение старшему, долг, справедливость, любовь к родине и т.п.); все это позволяет задать правильный вектор развития ребенка в современных условиях жесточайшей конкуренции, начиная с дошкольного возраста. Как известно, в китайских детских садах ребенок активно включен в образовательную деятельность: уроки родного языка, математики, музыки и английского вместо игр и прогулок на свежем воздухе, начиная с младшей группы (4 года) и вплоть до подготовительного класса (6,5 лет).

Книги рекомендаций по воспитанию содержат советы относиться к ребенку как к личности, (что для классического китайского образования неприемлемо), увещевают родителя «быть требовательным, но либеральным», «подавлять в себе раздражение из-за неуспехов ребенка в учебе», «соблюдать осторожность в высказывании неодобрения», «ставить незначительные проблемы ребенка выше своих интересов» [51]. Тем не менее, они транслируют ориентацию на конфуцианскую модель поведения, указывают, как научить ребенка следовать поведенческим клише, больше известным как «36 китайских стратагем» [40]. Изначально стратагемы применялись в военном искусстве, но затем получили широкое распространение, так как, по сути, они представляют собой план правильного действия в 36 жизненных ситуациях.

Популярность педагогической литературы, сочетающей китайский и западный подход, довольно высока, очевидно, вследствие переосмысления результатов тревожной статистики количества попыток суицида китайских подростков из-за низкой успеваемости в школе или неуспеха на экзаменах. В семьях распространены методы традиционного обучения, при которых многое достигается путем нравственного воздействия. Мировую известность получила этническая китаянка Эми 
Чуа (США), дочери которой воспитывались в крайней строгости, высоком ритме и верности целям, преследуемых пресловутой «матерьютигрицей». В КНР у всех на устах пример бизнесмена СяоБайю, написавшего книгу с говорящим названием «Папа-волк».Его трое детей поступили в Пекинский университет благодаря тому, что учились в рамках традиционного образования и не участвовали в деятельности, выходящей за рамки школьной программы [43; 278].

Итак, оба упомянутых примера видятся успешными с точки зрения достижения поставленной цели, так как дети преодолели высокий порог ожиданий родителей, смогли получить шанс обучения в престижных вузах, удовлетворили родительские амбиции в различных областях знаний и заняли первые места в мировых музыкальных конкурсах. И госпожа Чуа, и господин Сяо призывают своих последователей соблюдать определенные принципы китайского воспитания (приводятся с моими комментариями (Ю.И.)относительно западного подхода):

1. китайскому отцу и матери необходимо быть «строгими до деспотизма», в то время как западные родители «требовательны, но считают, что учеба может быть веселой»;

2. ребенок должен воспитываться только в ортодоксальной семье, полной или неполной, по обстоятельствам, но никак не в семье гомосексуалистов;

3. ученик непременно должен получить множество различных навыков, которые помогут ему преодолеть экзаменационные пороги;

4. дети воспитываются в строгости относительно вопросов пола и семьи, а не получают свободу в проявлении сексуальности;

5. китайской семье надо прививать детям чрезмерную бережливость, тогда как западные родители позволяют своим отпрыскам быть расточительными;

6. родителю, который желает своему ребенку успеха, приходиться быть прямым в оценке и не стесняться в выражении неодобрения;

7. учебный процесс подразумевает усердие, а не игру;

8. дети обязаны хорошо учиться ради спокойствия родителей, им не разрешено обсуждать свои права; 
9. детям необходимо сдерживать себя и беречь физическое тело, оно принадлежит клану, в то время как зарубежным сверстникам разрешается рисковать;

10. процесс воспитания не обсуждаем с детьми, он осуществляется внутри семьи, школа лишь принимает участие, но не считается ведущей в процессе воспитания;

11.родители должны муштровать, а не поощрять своих взрослых детей;

12.физический недостаток следует воспринимать как следствие неправильных кармических поступков, горе и презрение - вот истинные чувства, которые надлежит испытывать к немощным и калекам [45].

Интересно, что приведенные выше правила сформулированы Эми Чуа и Сяо Байю, социальное окружение которых совершенно различно, в виду того, что Э. Чуа выросла в семье китайских эмигрантов в США, а Сяо Байю проживает в континентальном Китае. Они оба придерживаются традиционных принципов китайского воспитания, которое нацелено на результат, возможно в ущерб близким отношениям с ребенком. Таким образом, мы можем наблюдать устойчивое сохранение матрицы конфуцианского воспитания, трактующего жесткое подчинение воле старшего, стремление к неустанному труду и послушанию.

В случае с Э. Чуа мы можем предположить, что ощущение этнической идентичности формируется у ее детей, отец которых - американец, по пути отрицания иной этнической идентичности, но вполне в рамках принятия национальной (американской) идентичности. В случае с этнической идентичностью госпожа Чуа подчеркивает положительный опыт воспитания, накопленный китайской культурой тысячелетиями, но преследует цели, которые помогут детям обрести достойное место в американской действительности.

Сяо Байю выстраивает свою линию в жесткой парадигме получения выгоды в конкурентной борьбе, в которую включены все китайские молодые люди в силу того, что КНР - самая густонаселенная страна в мире. Он репрезентирует свои методы воспитания в 
строгих рамках конфуцианских идей, следуя принятой модели поведения континентального китайца. Господин Сяо демонстрирует полную приверженность китайским национальным идеям, ориентируя своих детей на жизнь в китайской действительности, несмотря на то, что финансовые возможности обучать своих отпрысков за рубежом у него есть.

Интересный подход проявляют тайваньские родители, которые применяют базовые китайские навыки педагогики наряду с элементами, присущими японскому воспитанию:

1. Обучение может быть игровым, при этом мать должна подавать пример, переживая совместный опыт с ребенком. К слову, состоятельные семьи из континентального Китая стремятся перепоручить совместный опыт новейшей разработке домашнему роботу XiăoPàngzi 小胖子. Он запрограммирован на распознавание речи и является настоящей энциклопедией китайской классики и всего того, что требует школьная программа.

2. Тайваньская китаянка постарается сократить время вседозволенности поступкам ребенка, (который японцы определяют как возраст до 5 лет), из-за боязни потери лица и страха того, что ее ребенок может оказаться вне социальной группы.

3. Тайваньский ребенок, равно как и китайский, и японский, должен использовать конфуцианские обращения, которые определяют старшего в отношениях, например: «старший брат»ани 哥哥, «младший брат» отоото 弟弟, «старшая сестра» анэ 姐姐, «младшая сестра» имоото 妹妹. Такие лингвистические нюансы помогают внушить благодарность к взрослым и родителям, которые представляют собой эталон поведения.

4.И континентальные китайцы, и тайваньские родители позволяют себе проявление нежных чувств на уровне оценки ребенка как «драгоценности»băobao 宝宝, но тайваньские дети склонны выражать чувства к маме на уровне «обожания»амае (от англ. admire).

5. Вследствие немногочисленности населения Тайваня (около 23 млн человек), жители этого региона Китая не ставят перед собой 
задачу воспитать вундеркинда, который превзойдет остальных, но стремятся дать образование как необходимый старт в жизни.

6. По причине отсутствия жесткой конкуренции на Тайване не принято сравнивать детей, предпочтительнее оценка типа «победила дружба», «не стоит выделяться», «не надо противопоставлять себя коллективу».

7.В отличие от японцев, которые не поощряют детей за успехи сладостями, тайваньцы, как и континентальные китайцы, предпочитают угостить ребенка или организовать выход в ресторан.

8. Правильная реакция тайваньского ребенка на чужую беду формируется обществом как привычка провести анализ ситуации и помочь. Континентальный китаец предпочитает не вмешиваться, так как часты случаи вымогательств денежных сумм родственниками пострадавшего, считающих, что тот, кто оказывает помощь, повинен в происшествии.

9. Особое внимание следует уделить отношению тайваньских детей к домашним животным, за которым предстоит убирать, в том числе и на улице, дабы не причинять неудобства соседям. В континентальном Китае такая привычка не формируется намеренно, так как считается, что если есть человек, которому платят за уборку, то он должен отработать свою зарплату.

10.Трепетное отношение к деньгам воспитывается в обеих частях Китая: ребенку дарят суммы на китайский Новый Год и в день рождения в красных конвертах с надписью уāsuìqián 压岁钱, из названия следует, что «деньги растут вместе с ребенком».

11.Во всех регионах Китая одинаково воспитывают бережливость в духе китайской пословицы 《钱是挣出来的, 也是省出来的》 (qiánshìzhēngchūláide, yěshìshěngchūláide) букв. «деньги не только зарабатываются, но и сберегаются» [15].

На первый взгляд, тайваньские китайцы менее строги в воспитании, однако они четко следуют конфуцианской матрице, умело адаптируясь к современным условиям и реалиям тайванского общества, которое успешно осуществило модернизацию при скудных природ- 
ных запасах, внешнеполитической напряженности и сложных процессах внутренней политики. Главным своим богатством тайваньцы считают людские ресурсы, но акцент ставится не на дешевизну рабочей силы, а на особый островной менталитет, сочетающий в себе китайское трудолюбие, авантюризм в хорошем смысле слова (предки большинства тайваньцев перебрались в различное время с материка, преодолев различные трудности), а также приобретенное терпение. В этом заключается специфика островной идентичности.

Профессор Чжао Юн, долгое время работавший учителем в Китае и добившийся заметного успеха в научно-исследовательской деятельности в свою бытность в США, называет систему образования КНР «одной из лучших (и худших) в мире»[43].Он справедливо указывает на существование ощутимой разницы между глубиной знаний китайского школьника в области родного языка, классической литературы, естественных наук, английского языка, и ограниченности в познании фактов окружающей действительности, сведения о которых не входят в школьную программу. ЧжаоЮн считает, что китайская система воспитания и образования во многом напоминает имперскую систему экзаменов 科局 kējú, ориентированную на определенный свод знаний китайской истории и литературы, и указывает на очевидное фокусирование на этих областях науки. Вместе с тем, китайская система воспитания все же включает иностранные методики, близкие китайскому восприятию. Так, успех системы Монтессори в китайских детских садах напрямую связан с подходом запоминания наизусть, а не анализа информации. Китайский классический подход в обучении, ориентированный на заучивание, чтение, воспроизведение информации устно или письменно создает прочную основу для абсолютного успеха китайских школьников, которые занимают лидирующие позиции по версии международной аттестации PISA по математике, литературе и естественным наукам [43,111].

Методика заучивания позволяет китайскому школьнику тренировать память настолько хорошо, что студенты младших курсов языковых вузов легко осваивают лексический запас и качественно выполняют задание на пересказ незнакомого текста на иностранном 
языке, в то же время как лексико-грамматические задания могут вызывать многократные сложности. Приобретение экстралингвистических знаний, связанных с культурой изучаемой страны, не считается континентальными китайцами как обязательный элемент обучения, Это можно объяснить не столько отсутствием любознательности, сколько низкой мотивацией к фактам, познание которых требует понимания вещей, располагающихся за пределами китайской ойкумены и от того менее ценных.

Тайваньская молодежь отличается от своих континентальных сверстников бо́льшим интересом к миру вероятно в силу особенностей географического и политического положения современного Тайваня. Будучи островным государством, Тайвань долгое время представлялся находящимся за пределами Срединного государства, на периферии, в то же время именно островное положение помогает современному тайваньцу сформировать ощущение сопричастности к другим островным цивилизациям: японской, филиппинской, малайской и т.П. Длительная изоляция от континентального Китая в период колониального управления японцами привела к тому, что система воспитания и образования была сформирована по японскому образцу, у китайских тайваньцев были японские имена, что свидетельствует об определенной степени восприимчивости, толерантности и формировании такой национальной черты, как терпение. Изначально это явление трактовалось этнологами как возникающее в ответ на противостояние стихии, первоначальной неустроенности, память о которой еще жива, затем стало толковаться как рефлексия на специфику внешнеполитического положения Тайваня, гармонично вписавшегося в образ «Азиатского сироты», осуществившего экономическое чудо благодаря удивительным качествам тайваньского народа.

Действительно, специфика Тайваня, складывающаяся из множества факторов, определяющих его современное положение, позволяет этой части китайского народа осуществлять альтернативный путь развития искусственно отделенной немногочисленной части китайской нации, вступившей в сложные интеграционные процессы с группами некитайского населения и испытавшими в различные исто- 
рические периоды влияние как западной, так и восточной цивилизации. Для успешного развития страны как равноправной участницы мирового сообщества требуется и воспитание личности, которая бы соответствовала осуществлению главной задачи тайваньского правительства - вхождения в мировое сообщество в качестве Китая альтернативного пути развития.

Таким образом, мы можем утверждать, что китайцам (континентальным, островным и эмигрантам 华侨 huáqiáo) присуще проявление национальных чувств и настроений, которые выражают эмоциональное отношение к собственно этнической реальности, базовым национальным ценностям и национальному достоянию. Воспитание, получаемое детьми в континентальном Китае и на Тайване в общих чертах схоже, и в то же время носит ярко выраженную специфику, обусловленную разницей альтернативного развития этих двух частей Китая: центростремительного в КНР и более ориентированного на глобальное сообщество на Тайване. Будучи одним из базовых факторов влияния на процессы самоопределения, наряду с образованием, профессиональной занятостью, местом жительства и социальной мобильностью, воспитание позволяет сформировать человеку понимание своей роли в обществе, осознание личных интересов и помыслов в общественной деятельности и закладывает основу осознания национальной идентичности.

\section{2. Женщина в современной конфуцианской культуре}

Номинально все граждане КНР и КР, вне зависимости от проживания, имеют право на получение бесплатного среднего образования в начальной школе и в среднем звене, за обучение в старших классах государственной школы ранее взималась фиксированная плата. На деле, для того, чтобы получить бесплатное образование на этом уровне, необходимо иметь прописку 户口 hùkŏu, позволяющую посещать образовательное учреждение по месту жительства. До недавнего времени в континентальной части Китая дети, рожденные в нарушение политики ограничения рождаемости, могли посещать школу только платно. 
В КНР, где есть районы, в которых организация школ невозможна в силу территориального расположения или малости населенного пункта, поэтому детям приходится преодолевать горные ущелья по канатному переходу или покидать родные семьи, чтобы добраться до школы по речному льду, как только река замерзнет. Если принять во внимание статистические данные по урбанизации, становится понятно, что количество школьников, которые проживают в сельских районах, и потому находятся в менее выгодных условиях, достаточно велико. На 2015 г. КНР сообщала об уровне урбанизации от $56,1 \%$, в то время как в КР в 2010 г. урбанизация достигла до 99,8 \% [43].

По мнению профессора Чжао Юна, у городских школьников есть прекрасные возможности получить дополнительные баллы для поступления в вуз за счет успешных достижений в спорте, освоении английского языка, музыке, каллиграфии, рисунком тушью и маслом и тп, так как их семьи располагают материальными возможностями и территориальной близостью школ, оказывающих дополнительные образовательные услуги [43].С ростом доходов населения и развития транспортной инфраструктуры у городских семей появилась, к примеру, возможность брать уроки фортепиано стоимостью в 2000 китайских юаней за занятие, совершив поездку к именитому учителю в Пекин и обратно на скоростном поезде 高铁 gāotiěв тот же день. Для сельских жителей с их низким доходом такие возможности закрыты. На Тайване, в силу его островного положения, цивилизационный центр оказывается на побережье, инфраструктура и транспорт развиты достаточно для того, чтобы устранить фактор труднодоступности образованных учреждений, стоимость дополнительных образовательных услуг вполне доступна для среднего класса.

Немаловажным является наличие силы воли, благо китайская повседневность репрезентирует массу примеров, когда недостаток материальных средств и возможностей закаляет характер и является мощным стимулом к победе. Часто делаются исторические отсылки, например, к таким деятелям эпохи Хань, как министр КуанХэн, который в юности не имел возможности купить масла для лампады и учился при отсвете лампы своего соседа, жившего через стену. Попу- 
лярны изречения, подчеркивающие необходимость терпения, воли к преодолению трудностей в учебе. Так, на территории школы или университета на видных местах располагают стенды с известными речениями конфуцианских классиков. Например, изречение Мо-цзы: 《志不强者智不达，信不信者行不果》 (zhìbùqiángzhězhìbùdá, xìnbùxìnzhěxíngbùguŏ), которое переводится как «Слабый волей не познает мудрость, слабый верой не придет к результату».

Привлекательная внешность и высокий рост в последнее время стали играть решающую роль в получении образования и дальнейшем трудоустройстве. Так, в июле 2018г Шаньсийским педагогическим университетом было отказано в выдаче диплома девушке ростом140 см в виду того, что по требованиям правительства провинции Шаньси, школьный учитель (мужчина) неможет быть ниже 155, учительница - ниже 150 см. Такие же требования, согласно медиаресурсу TheSixthtone, существуют в Гуаньси-Чжуанском автономном районе КНР [69].

Существенным фактором является и воля родителей в отношении социальной мобильности детей: получение образования для сына будет более приоритетным, чем для дочери. Впрочем, такой подход в семьях со скромным достатком является традиционным, а в свете послабления политики ограничения рождаемости, позволяющей ханьской семье иметь второго ребенка, будущее дочери видится скорее внутри семьи, в замужестве, рассматриваемом как улучшение жизненных условий. В некоторых случаях посредством замужества дочери решаются некоторые проблемы, например, денежного займа и тп. Состоятельные семьи стремятся дать качественное образование и сыну, и дочери. Последние, чаще всего, реализуют себя в области дизайна, сфере международных отношений, творческих профессиях, предварительно получив образование в США, Канаде, Англии, Австралии.

В XX веке были проведены серьезные реформы в области законодательства: сначала Конституция Сунь Ятсена, а затем законодательная база Нового Китая существенно изменила статус отношений внутри общества, дотоле жившего по законам эпохи Тан. С 1980 по 
2001 гг. государство руководствовалось Законом о браке, включавшем 5 глав и 37 статей, в нем впервые на законодательном уровне было запрещено «душить, топить, закапывать живьем младенцев женского пола». Новый Закон о браке состоит из 6 глав и 51 статьи, значительно проработаны вопросы расторжения брака и мер по оказанию помощи и ответственность сторон [72]. В последней доработке «ЗаконаКНР о защите прав и интересов женщин» в августе 2005 китаянки получили право на помощь в случае домашнего бытового и сексуального насилия, а также компенсации в случае супружеской измены.

Регулирование семейных конфликтов не входит в функции полиции, поэтому существенным шагом стало создание в 2005г Всекитайской женской федерацией Национального центра правовой помощи женщинам, для оптимизации работы которого была открыта круглосуточная телефонная линия помощи жертвам домашнего насилия. Судебными администрациями в 2007 г. было открыто порядка 2700 юридических консультаций, специализирующихся на правовой помощи пострадавшим гражданкам. Кроме того, в настоящее время под патронажем Департамента по гражданским делам функционируют 400 женских приютов, еще 350 травмпунктов оказывают помощь в определении степени тяжести нанесенных побоев. Иностранные жены китайцев, попадающие в ситуацию бытового насилия, скорее предпочитают обращаться к помощи соотечественников, чем в органы общественной безопасности, очевидно, сказывается нежелание доводить дело до судебного разбирательства и национальный менталитет потерпевшей. В сети нередки обращения гражданок РФ и Украины, состоящих в браке с гражданином КНР, к русской диаспоре, проживающей в разных городах КНР. В большинстве случаев приходится прибегать к юридическим уловкам как-то: подача заявления в полицию после бегства из дома, с предъявлением обвинения в избиении или двоеженстве. В отличие от большинства китаянок, при расторжении брака россиянки и украинки стремятся оставить за собой право совместного проживания с детьми, поэтому подача гражданского иска происходит при посредстве адвоката, когда женщина находится на родине. Материальные компенсации в таком случае 
редки, и являются исключением (например, нашумевшее дело А. Кораблевой, которая смогла оставить детей, получить развод и денежное возмещение причиненного здоровью ущерба от бывшего китайского мужа-боксера) [65]. Китаянка руководствуется принципами конфуцианского уклада, по которому ребенок, рожденный в клане отца, должен остаться в его семье, то есть на уровне культурной релевантности такое поведение считается нормой.

В настоящее время законодательная база защиты прав и интересов женщин сформирована, а продолжающаяся работа по достижению гендерного равенства в общественно-политическом, образовательном и экономическом пространстве является одним из приоритетных направлений развития. В данном вопросе китаянки из Тайваня имеют больше реализованных прав, к примеру, госпожа ЦайИнвэнь с 2016г занимает пост президента КР, в то время как подобные перспективы для континентальных китаянок возможны на законодательном уровне, но фактически не реализованы.

Тем не менее, по доброй китайской традиции, «все возможно, но в неопределенный срок», и пока КНР успешно реализует проект оперативной системы «Национальной программы развития женщин», хронологические этапы которой пришлись на период 1995-2000гг, 2001-2010гг и 2011-2020 гг. Инициативная группа проекта при содействии общественных организаций разрабатывает 34 программы реализации включения женщин в различные области общественной и экономической жизни, улучшения медицинского обслуживания.

Директивы передаются для осуществления соответствующим правительственным ведомствам, на уровне провинций и автономных районов. Финансируемая правительством программа выделяет шесть направлений развития: обеспечение прав на равное участие в управлении национальными и социальными делами; расширение занятости и улучшение структуры карьеры; сокращение разрыва в общем уровне образования между мужчинами и женщинами; улучшение здоровья и повышение качества жизни; юридически защищенные личные права и права в браке и семье; усиление чувства собственности и потенциала [70]. Соответствующие стратегические цели про- 
писаны Правительством КНР в «Десятый пятилетний план национального и экономического развития».

КНР активно сотрудничает с международными организациями, так, в 1980 г. была подписана Конвенция ООН о ликвидации всех форм дискриминации женщин. В рамках конвенции, при сотрудничестве с ведущими университетами (Цинхуа) и высшими партийными школами (г. Пекин, провинции Гуандун, Цзянсу) ведется работа по соблюдению прав и расширению возможностей женщин и гарантирования равенства полов: обеспечение участия женщин во всех аспектах общественной жизни, устранения гендерных диспропорций в сфере занятости, установления одинаковой оплаты труда и укрепления права женщин на собственность и наследования. Большое внимание уделяется положению женщин-мигрантов, пожилых и одиноких преклонного возраста. Долгожданный «Закон КНР об охране здоровья матери и ребенка» принят в 1994 г., поправки внесены в 2009 и 2017 гг. Согласно этому закону, женщина имеет право на искусственное прерывание беременности без согласия мужа или на наблюдение врача на весь срок беременности. На деле за медицинскую помощь приходится платить, а оперативное вмешательство, связанное с введением наркоза, требуют подписи мужа пациентки или родственников. Порою происходят потрясающие по своей циничности случаи, когда роженице не оказывают помощь в родовспоможении из-за того, что семья не считает операцию кесарева сечения необходимой (скорее из-за финансовых обстоятельств, так как естественные роды дешевле в три раза). Однако по причине осуществления многовековых телесных практик, таких, как бинтование ног и как следствие, патологическая узость костей малого таза, большинству китайских рожениц эта операция показана. Вопиющий случай произошел зимой 2010 года, когда в северо-восточной провинции Хэйлунцзян в приемном покое больницы умерла в родах молодая женщина, муж которой отказывался подписывать согласие на оперативное вмешательство. При расследовании выяснялось, что сопровождавший официально не состоял в браке с умершей, и права подписи не имел [68].

Этим же законом запрещается сообщать будущим родителям о результате проведения процедуры по определению пола ребенка на 
УЗИ, нарушители строго наказываются, так как разрешение на прерывание беременности на больших сроках беременности позволяет родителям девочки избавиться от нее до рождения. В некоторых провинциях на юге Китая, где в далеких деревушках культурный уровень низок, а материальный достаток невысок, существует неприглядное явление продажи человеческого эмбриона на большом сроке развития в подпольные рестораны, торгующие специфическими блюдами по высокой цене [64]. Китайское государство активно борется с такими феноменами мракобесия и отсталости. Тем не менее, достоянием общественности периодически становятся подобные происшествия, а сюжет романа «Страна вина» китайского метра Мо Яня сподвиг организаторов ежегодного вручения Нобелевской премии в области литературы номинировать писателя именно за это произведение. К чести метра, он пытался предложить свой другой роман, «Лягушка», что при известной омофонности китайского языка, слышится как «Ребенок». В романе поднимается другая проблема периода реализации политики ограничения рождаемости - жизнь пожилой акушерки, которая раньше помогала людям рождаться, а теперь помогает не рождаться [61]. За последние три года, которые прошли с момента официального разрешения правительством КНР рождения второго ребенка, многие китайские семьи обзавелись желанным потомством. Это смогли сделать люди, чей достаток превышает 500 американских долларов на члена семьи в месяц, а также те, кто не прибегли к настоятельно рекомендованной при рождении первенца манипуляции по перевязке маточных труб. Тем не менее, в Китае на пике бэби-бума, нашедшего отражение в красноречивых названиях многочисленных сериалов и романов сетевой литературы (например, Линь Лин «Раба ребенка», 林铃 《孩奴》 «Нái nú» и т.), определенная часть китайских пар в возрасте 35-45 лет предпочитают оставаться бездетными [60]. На Тайване в среднем приходится по 2 ребенка на семью, хотя женщины среднего возраста с высшим образованием точно так же, как и континентальные китаянки с теми же возрастными и образовательными характеристиками предпочитают экономическое благополучие и возможность реализовать себя в карьере. 
Большой вклад в повышение качества жизни женщин КНР вносит политика в области образования, которая стабильно включает в образовательный процесс китаянок в возрасте от 18 до 65 лет, проживающих в сельских районах. Правительство преследует следующие цели: повышение общего культурного уровня, повышение уровня и качества и продолжительности жизни, сохранение женского здоровья и осознанный подход к рождению детей. Начиная с 1990 г., продолжительность непрерывного образования в младшем и среднем звене национальной школы КНР среди женщин выросла с 4,7 года до 8,8 лет, приближаясь к аналогичному показателю среди мужчин, которые стали учиться также значительно дольше, с 6,6 лет в 1990 г. до 9,1 г. в 2010 г. К сожалению, получить высшее образование попрежнему может только каждая третья континентальная китаянка в возрасте до 25 лет [66]. В силу того, что Китайская республика осуществила процесс модернизации общества гораздо раньше, к концу $\mathrm{XX}$ в, программы непрерывного обучения для женщин, адаптация к образовательному процессу женщин в возрасте 50-70 лет, ранее не получавших образование, включение в образование домохозяек широко реализуются с начала XXI века повсеместно. К обучающимся применяют личностный и деятельностный подходы, что позволяет обучающейся реализовать свои возможности в занятости трудовой и образовательной деятельностью в любом возрасте.

С включенностью китаянки в изменяющуюся социальную систему, возникают новые функции, которые женщинам приходится выполнять, причем именно эти функции носят облигаторный характер: чем более мобильна в социальном или академическом плане женщина, тем выше ожидания социума к реализации ею своих амбиций. С точки зрения традиционной семьи, место женщины внутри, отсюда возникают функции, которые китаянка выполняет, находясь в естественном состоянии, не выведенном за рамки ожидаемого:

1.Институциональная функция - заключается в соответствии женщины занимаемому ею положения в семье 家 јіа̄и обществе 社会 shèhuì. Обращаясь к этимологии происхождения названия и его фиксации в иероглифике, мы можем проследить, как ожидаемо реализу- 
ется эта функция: в семье, значит под крышей, в доме, где есть хозяйство (графема «свинья», расположенная ниже графемы «крыша») и в обществе, название которого по-китайски отражает точную его функцию («алтарь, объединяющий собравшихся вокруг него»). Таким образом, женщина функционально организована как член семьи (внучка, дочь, сестра, мать, тетя) и потенциальный отправитель ритуалов культа предков. Строго говоря, эту функцию должен выполнять только мужской потомок, дабы не вносить хаос в гармонию инь и ян, однако в некоторых случаях, ранее описанных в научной литературе, женщина может осуществить переход из инь в ян, принимая пилюли, прекращающие ежемесячные очищения. Учитывая тот факт, что в китайской культуре каждая женщина занимает отведенное ей положение (жены, наложницы, в современном обществе 小三 хіӑоsān или 小 媳妇 xiăoxífu,побочные жены, и некоторые другие, иногда действующие вне закона, но в точки зрения китайского общества, вполне с осознанием собственной социальной ответственности).

2. Репродуктивная функция - происходящая в соответствии с законом бытия, и наиболее естественная для китаянки на протяжении всей китайской истории. Фактически навсегда оставаясь в клане своего отца, (что фиксируется в фамилии и имени, данном при рождении), ни континентальная, ни островная китаянка в абсолютном большинстве случаев не меняет фамилии отца при замужестве), женщина порождает потомство клана своего мужа. С точки зрения китайской традиции, женщина, по сути, есть средство для воспроизводства населения, и, несмотря, на ощутимые подвижки в мировоззрении, выражающимся в общественном одобрении роли матери и в восхищении этой ролью, что дало возможность прижиться на китайской почве Празднику матери, отмечаемому в конце мая, в сельских районах КНР на женский вопрос смотрят по старинке. Пожалуй, в этом и заключается природа когнитивного диссонанса, когда наслышавшиеся о стремлении китайских мужчин к традиционности, некоторые россиянки и жительницы ближнего зарубежья с легкостью выходят замуж, не имея точного представления, что подразумевает под собой 
китайская повседневность. Отсюда непонимание особого статуса свекрови, а также неспособность сопротивляться в том случае, когда традиционность поворачивается темной стороной: нередки случаи привода в дом новой жены-китаянки, ожидания новоиспеченной китайской парой рождения наследника от жены-иностранки с последующей отправкой ее на историческую родину без малыша, в легких случаях - табу на плотное общение с соотечественниками. Суровая правда жизни описывается попавшими в беду традиционализма на просторах масс-медиа, чаще с призывом к помощи или совета. Названия веток говорящие: «Китайские свекрови», «Китайские мужья», «Помогите, муж отнимает ребенка» и тп. К величайшему сожалению, здесь порою просят совета и помощи те, кто совсем недавно размещал фотографии в ветке «Мы-пара!» и хвалил шанс иметь второго и последующего ребенка от смешанного брака, в котором китайский супруг явно сочетал приятное с полезным - рождение многочисленного потомства благодаря юридической возможности присвоить ребенку иностранное гражданство [63].

3. Воспитательная функция - традиционно принадлежит мужу, но учитывая меньшую занятость женщин, за подготовку к школе, сопровождению в образовательное учреждение и посещение всевозможных дополнительных занятий берут на себя либо старики, либо мать ребенка. Китайская история свидетельствует о том, что и под женским руководством вырастали образцы конфуцианской мудрости, например, Мэн-цзы. Как известно, его мать, жизнь которой вошла в свод Официальных жизнеописаний, совершила нравственный подвиг. Утратив мужа, она отказалась от ритуального самоубийства, но посвятила себя воспитанию истинного конфуцианского ученого. В хрониках ее имя сохранилось как 孟母 Mèngmŭ, (мать Мэна из Цзоу),что само по себе отражает важность воспитательной функции, которую она выполнила блестяще.

4.На современном этапе у китаянки возникает общественная функция, причем, теперь она репрезентирована в системе социальных отношений, ранее закрытых для женщины. На высоком уровне - это олицетворение китайского государства в женском лице, либо в каче- 
стве представительницы правящей фамилии (императрица Цыси, жена Чан Кайши СунМэйлин, нынешняя госпожа президент Тайваня ЦайИнвэнь), либо в качестве супруги своего высокопоставленного мужа (здесь скорее, уместен пример госпожи ПэнЛиюань, второй жены Председателя КНР Си Цзиньпина). ПэнЛиюань образованна, имеет степень магистра китайской национальной вокальной музыки, активно включена в деятельность ВОЗ и занимается предотвращением детской преступности). На уровне повседневности каждая замужняя женщина функционирует как женское начало семьи мужа. Характерно сохранение этикетных форм обращений, как-то 我的先生 wŏdexiānsheng «мой господин» (в разговоре с посторонними), либо 老 公 lăogōng «уважаемый муж» (в бытовом общении и при непосредственном обращении к супругу). Последнее обращение несет яркую эмоциональную положительную окрашенность.

5. Производственная функция-появилась у китайской женщины в активный период строительства Нового Китая. Законодательно отношения на производстве регулируются на основе: «Правила охраны труда женщин» и «Временных правила охраны здоровья женщинрабочих и служащих», в статьях которых, ко всему прочему, прописаны меры диспансеризации женщин с целью профилактики и своевременного лечения заболеваний [71].

Несмотря на стремительное изменение статуса китайской женщины, по-прежнему основополагающим фактором, регулирующим абсолютно все аспекты ее включения в модернизированное сообщество, все же остается фактор традиционного понимания положения женщины в китайском универсуме, трактующий ее нахождение внутри (семьи, клана, социального института). В связи с этим, на наш взгляд, остаются актуальными матримониальные проблемы, приводящие к возникновению в реальной жизни и за ее пределами явлений, которые могут быть приняты чаще на уровне культурной релевантности [16].

Брачный возраст в КНР претерпел значительное снижение (с 25 лет для мужчин и 23 лет для женщин в 1994 г. до 22 лет для мужчин и 20 лет для женщин в 2018 соответственно), большинство моло- 
дых людей в континентальном Китае стремятся вступить в брак тогда, когда позволяет финансовая ситуация и найден подходящий партнер (приоритетно, по любви). На Тайване брачный возраст по достижению 20 лет установлен как для мужчин, так и женщин, однако последние предпочитают вступать в брак после того, когда их обучение успешно завершено, а карьера стабильно развивается. Здесь явно прослеживается влияние американского образа жизни, когда женщина не стремиться стать нянькой, а пользуется благами глобализации, такими как, возможность реализовать права на невмешательство личную жизнь и свободу выбора. Старшее поколение семьи, тем не менее, озабочено новыми тенденциями и активно занимается устройством брака сына или дочери. Территориально наблюдаются различия в подходе решения этой проблемы: на северо-востоке Китая чаще прибегают к услугам свах, которые устраивают смотрины 相亲 xiāngqīn, в юго-восточных районах родители лично посещают ярмарки женихов и невест. Эти мероприятия не лишены самобытного колорита, чаще напоминают уличный стихийный рынок, на котором претенденты выкладывают фотографии потенциальных супругов с подробным указанием материального положения, уровня образования, не обходится и без привычного китайскому глазу набор характеристик по фэншуй (год, месяц и дата рождения по лунному календарю, дабы стихии, соответствующие каждому из супругов были гармоничны в браке). В Шанхае такой рынок находится близ станции метро Народная площадь, и в первую половину дня в выходные дни здесь множество стариков, которые подыскивают пару своему чаду. Можно разместить брачное объявление на стенде, плата взимается по тарифу, от 25 юаней в месяц. Нередко сватовство выглядит комично, и эта тема стала популярной в театральном искусстве, например, миниатюру в жанре северо-восточного сказа эржэньчжуань под названием «Сватовство» в исполнении всенародно любимого метра эстрады Чжао Бэньшаня, включают в весенние новогодние концерты на CCTV. В цифровом пространстве китайского интранета также действуют свахи, так, в шанхайском метро размещены предложения скачать 
APР-приложение 红本本 Hóngběnbĕn и быть в курсе конъюнктуры рынка.

Отдельной проблемой является осуществление процедуры посмертного брака. Возникновение феномена посмертного брака специалисты относят к доконфуцианской эпохе, в научной литературе подробно описаны случаи сопогребения жен и наложниц умерших правителей, начиная с доциньской эпохи. Конфуцианство трактует о необходимости соблюдения брачного ритуала абсолютно как для живых, так и мертвых. Синкретичный характер китайских верований и учений, с различных аспектов рассматривающих вопросы человеческого бытия и небытия, позволяет сформировать единую точку зрения на метаморфозы, которые происходят с человеком после его смерти. Загробная жизнь рассматривается как часть бытия: в лунном мире все устроено также как и в солнечном. Если в результате болезни или несчастного случая безвременно уходит из жизни незамужняя девушка или неженатый молодой человек, необходимо провести ритуал посмертного брака, для которого выбирают недавно умершую девушку, так как осуществление такой процедуры с пожилыми дамами невыгодно семье - невестку надо содержать. В газетах появляются публикации о случаях незаконной эксгумации женских трупов с целью их продажи, либо об убийстве молодой женщины с той же самой целью. Согласно сообщениям, такие случаи происходят в юговосточных регионах Китая, и в Гонконге. Свадебная церемония проводится, как и при обычной свадьбе, в счастливый день по фэншуй, на пороге жилища оставляют саван, фотография молодой помещается на алтарь предков мужа. Церемония заканчивается погребением. Родственники «новобрачной» могут взять выкуп, чаще всего в виде денежной компенсации, точно так же, как если бы они получили ее при жизни дочери.

Таким образом, жизнь женщины регламентирована и при ее земном существовании, и после смерти. Это обусловлено самим подходом китайцев к определению места человека в социуме, буквально 身份 shēnfèn. Китаянка изначально занимает позицию телесной при- 
надлежности (родителям, мужу), и выше уровнем, принадлежностью к семейному и социальному положению (жена, в старом Китае наложница, гетера и тд). В модернизированном Китае появляется принадлежность институциональная, вытекающая из новых функций. Телесная принадлежность семье обуславливает поведение - стремление почитать родителей, как людей, давших физическое тело, диктует иные нормы культуры быта, например, плевок или отправление естественных нужд в неподходящем месте выходит за рамки понимания культурности, но вполне гармонично в парадигме сохранения здоровья физического тела и избавления от отработанных части 气 qì.

Модернизированное общество определяет новый тип социальных отношений, в которых на начальных этапах происходит культурная гомогенизация, предопределяющая частичное смешивание гендерных ролей. Однако с течением времени традиционное начало гармонизирует отношения, фиксируя место женщины в современном китайском обществе с учетом тех функций, которые ей предопределено выполнять, одновременно устанавливая рамки социальной мобильности в пределах отведенного судьбой и изначально обозначенного волей семьи.

\section{3. Символические формы поведения современных китайцев}

Традиционно выделяемые нормативная и аксиологическая функции культуры реализуются только при условии взаимного дополнения друг друга: первая регламентирует нормы поведения и общения, вторая утверждает определенные ценности и формирует нравственные ориентиры в пределах заданной нормы. В эпоху успешного осуществления масштабных модернизаций в КНР наблюдается процесс незначительной трансформации форм символического поведения, несомненно, отражающий общемировую тенденцию к нарождающейся глобальной культуре.

Приступая к исследованию некоторых феноменов китайской повседневности, необходимо наметить основные точки на шкале символических форм коммуникации, обозначив ритуал и обычай как 
предельно отстоящие друга от друга. По мнению А.К. Байбурина, под ритуалом «понимается принадлежность области сакрального», а также характеристики стереотипности и обязательности, с градацией неблагополучия в случае невыполнения (или ненадлежащего отправления ритуала) [3]. Высшей степенью ритуализации выступают обряды, от выполнения которых зависит жизнь коллектива, низшей - обычаи, регламентирующие повседневную жизнь и по последствиям несущественные для коллектива в целом.

Традиция считается более долговечным, передающимся от поколения к поколению знаком культуры, в то же время обычай - как форма символического поведения, реализуемая на уровне реальной бытовой жизнедеятельности. В поведенческой шкале китайской повседневности также большое значение по-прежнему играет церемониал, репрезентирующийся в этикетных нормах, в бытовом общении (на вербальном и невербальном уровне), а также при официальноделовой коммуникации.

Полевые исследования на уровне повседневности являются наиболее информативными, так как они дают возможность проследить динамику символических форм поведения носителя китайской культуры в современном обществе, а также обозначить тенденции к появлению новаций в заявленной сфере. Некоторые формы повседневного общения, например, проявление гиперопеки 体贴 tĭtiē становятся более облигаторными, чем это было ранее, вследствие нарастающей популярности к их сохранению в традиционном виде, вероятно в парадигме «вызова и ответа» глобализационных процессов и традиционной культуры.

Процессы глобализации на начальном этапе создают иллюзию культурной гомогенности, так как при поверхностном взгляде все страны, участвующие в процессе, становятся одинаковыми: бывалый путешественник свободно ориентируется в инфраструктуре аэропорта, транспортном сообщении, метро, видит одинаковые постройки с аналогичным назначением по всему миру, посещает телебашни, которые соревнуются между собой в высоте и т.п. Эта легкость обусловлена тем, что глобализация способствует стиранию различий во 
внешнем облике города или туристического объекта. И даже в не совсем обычных местах, на самом пике горы, куда предстоит подняться на скоростном стеклянном лифте в парке Чжанцзязце (КНР), можно гарантированно получить возможность перекусить в ресторанах быстрого питания KFC и Mcdonald's, пионерах глобальной массовой культуры.

В современном китайском обществе на социентальном уровне западные культурные ценности восприняты (вряд ли будут приняты полностью и до конца), локализированы, переработаны, осмыслены и по старой доброй традиции, соотнесены с фактами и прецедентными событиями, имевшими место в высокой китайской истории и самых истоках конфуцианства. Ввиду того, что китайская культура может оперировать целыми тысячелетиями, достижения западной духовной и материальной культуры воспринимаются как нечто молодое, специфическое, но еще не прошедшее проверку столь длительным временем.

И в Китае, и на Тайване формирование глобальной массовой культуры четко прослеживается как в классовых, так и возрастных границах: молодежь, особенно городская, активнее включает в свой мир ценностей символы американской и/или корейской (на северозападе и в центральных регионах КНР) и западной и/или японской культуры, (на юго-восточном побережье и на Тайване). Пожилая часть населения, сельские жители и рабочие северо-востока и центральных провинций континентального Китая вряд ли могут пополнить ряды течения 哈日族 Hārìzú, благосклонно реагирующих на все японское и обожающих абсолютно все, что порождает японская массовая культура.

Тяготение к традиции обнаруживается не на потребительском уровне, а на уровне символического поведения, так как традиционность проявляет себя там, где высокий ритм современной жизни замедляется в виду того, что отправление религиозных, социальных и психологических ритуалов не терпит спешки. Китайская традиционная культура неразрывно связана с ритуалом и обрядом, назначение которых - регулировать эмоциональное состояние людей, формировать культурную идентичность. Человек озабочен поддержанием сво- 
его психологического статуса, удовлетворению материальных запросов, в ритуале - реализации духовных устремлений, так как последний считается более высокой степенью регуляции поведения. И ритуал, и обычай несут специфические черты национальной культуры, формируя и совершенствуя ее семиотическую систему.

В основе традиции лежит длительный опыт социальной группы язык, символика и знаковая система, через которую культура способна репрезентировать себя, так создаются сценарии поведения человека и реализуется нормативная функция культуры. Если рассматривать сценарии поведения китайца с точки зрения принадлежности к ритуалу, обряду, церемониалу или обычаю, то не всегда удается проследить четкую грань принадлежности той или иной формы поведения. Так, отправление процедуры поклонения культу предков с точки зрения культурологии является таковым и может быть отнесено к ритуалам, осуществляемым по лунному календарю (в День Поминовения Усопших 清明 Qīngmíng, в День Кормления Духов 中元 Zhōngyuán, в Праздник Двойной Девятки Чунъянцзе 重阳节 Chóngyángjié). По сути, ритуал общения с животными душами предка 嵬 pò, навеки сокрытыми в физической оболочке ушедшего, есть молитва, то есть обращение личного духа к личному же духу. Действу предшествует пост, оно сопровождается воскуриванием благовонных палочек, докладом старшего мужчины в роду о состоянии дел, просьбой помочь решить материальные проблемы, порою - сетованием и намеком на возможность выбрать себе для поклонения другого предка. Подобная легкость общения китайца с душами предков имеет реальную угрозу для них остаться «некормлеными». Голодные духи способны беспокоить живых, поэтому в континентальном Китае их питают в Праздник Чжунъюань (15 день 7 луны), в Фуцзяни и на Тайване проводят специальные выносы божеств народной религии (Мацзу, Чэнхуан, Баошэнди и др.), одним из этапов проноса статуй богов по местности является кормление голодных духов [12].

Ритуал поклонения культу предков может осуществить только мужчина, дабы не было внесено хаоса в гармонию 阴 yīn и 阳 yáng. 
Актуальность и живучесть традиции поклонения культу предков подтверждается фактом существования гендерного перекоса в пользу мужчин почти в 50 млн человек возраста 20-30 лет. В 2010 г было объявлено об официальном введении трех выходных дней на День поминовения усопших (清明 Цинмин) в КНР, что дает возможность работающему китайцу добраться к месту захоронения предков из любой точки Китая. К слову, несмотря на сложные внутриполитические проблемы, существующие между континентальным Китаем и островным Тайванем, даже в самые трудные времена гоминьдановцам, ушедшим на Тайвань вслед за Чан Кайши, разрешалось раз в год посещать могилы предков на материке по упрощенной схеме въезда. В обеих частях Китая сложился обычай оставлять на могиле четное количество фруктов, через три дня, когда они напитаются энергией, положено забирать нечетное количество с тем, чтобы накормить ими детей клана. Так осуществляется процесс общения давно ушедших с самыми младшими членами семьи. На кладбища принято приезжать семьями, что с ростом доходов китайцев и увеличением числа личных автомобилей приводит к образованию многокилометровых пробок по направлению к кладбищам близ мегаполисов.

Процедура ритуала меняется мало, но возникают новации, касающиеся увеличения ассортимента атрибутов, «отправляемых» в выше перечисленные праздники душам предков: если раньше сжигались бумажные деньги, бутафорные золотые слитки и стопки испещренных иероглифами молитв, то теперь можно увидеть бумажные дома и даже бутафорские модели автомобилей представительского класса. Это делается для того, чтобы обеспечить предка всем необходимым и дать шанс откупиться от чертей с говорящими именами Лошадиная Морда Mă Miăn 马面 и Коровья БашкаNiú Tóu 牛头, которые могут избавить от прохождения того или иного зала пыток в китайском аду, идея которого была заимствована из буддизма. Процедура отправки может осуществляться в совершенно неожиданных для иностранца местах - на перекрестке дорог, который считается порталом в мир духов. В благополучных районах с целью повышения культуры быта 
и сохранения пешеходных переходов устанавливают треножники 鼎 dǐng, это практично и, вместе с тем, воздается дань традиции, ведь такие треножники использовались для подобных целей еще в доциньскую эпоху. Таким образом обеспечивается дальнейшее развитие повседневного общения между ныне живущими и бестелесными обоготворенными душами предков: путем моления на кладбище - животным душам одного и того же человека и путем молитвы человеческим душам 魂 hún и процедуры подношений 供赏 gōngshăng на алтарь предков, установленный практически в каждом китайском доме. У одного усопшего, по народным верованиям, от 3 до 5 человеческих душ, которые отходят посмертно до 9 дней, животные души должны быть правильно упокоены и навсегда остаться в теле.

Традиционный погребальный обряд описан в научной литературе подробно, например, в работе Л.С. Васильева [6]. В современном Китае он приобрел значительные изменения, так как ожидание «счастливого дня» для захоронения по фэншуй при такой популяции населения невозможно, а традиционно предписанное захоронение в землю вряд ли может быть соблюдено, так как стоимость участков земли доходит до нескольких сотен тысяч юаней. Кремация рекомендована повсеместно, кроме районов КНР, где по обычаям положены похороны в воду или небесные похороны. Родственникам государственных служащих, учителям и некоторым другим категориям граждан выплачиваются суммы на погребение размеров до 30 окладов, если кремация состоялась.

В связи с тем, что на погребение положено дарить определенную сумму, чиновникам на законодательном уровне запрещено приглашать знакомых на похороны родственников, дабы препятствовать коррупции. Специально назначенный человек подсчитывает, сколько денег положено в конверт (белого или розового цвета), выдает примитивную шапочку для мужчин и повязку на руку из некрашеной ткани для женщин. Так маркируются участники процессии, одетые в одинаковые яркие костюмы. Похоронная процессия организуется по счастливому предзнаменованию, определяемому гадателем, если фи- 
нансы позволяют держать тело в морге до положенного дня. Последнее омовение производят родственники, это не считается дурной приметой, покойного выставляют на три дня либо в общий двор под специальный навес, либо оставляют в гостиной дома. В течение этого времени родственникам спать возбраняется, они находятся рядом с телом, периодически кричит кликуша, подают угощения и семечки. Перед выносом со двора положено, кроме жертвенных денег и траурных венков, поднести покойному коня, покойнице - корову, выполненные из папье-маше или дерева. Покойному также преподносится фигурка животного, соответствующего «земной ветви» китайского зодиакального цикла. Так, человек, рожденный в год Петуха, посмертно получает его фигурку, бережно приготовленную для загробного существования.

Перед самым отправлением возжигают поминальные свечи, по три на каждого участника процессии, устраивают салют из петард, затем гроб устанавливают на торжественно оформленный грузовик. Церемония может сопровождаться мужским или женским оркестром, исполняющим спокойные, не надрывные мелодии. На задних стеклах автомобилей, следующих в крематорий, размещают цифру, соответствующую возрасту покойного. В связи с дороговизной земли в наиболее выгодном, с точки зрения традиционного погребального ритуала, положении, оказываются крестьяне, тела которых хоронят гденибудь с краю обрабатываемого поля. Кремацию производят в тот же день, пока процессия передвигается по благоустроенном парку крематория после прощания с близким, тело предают огню и выдают родственникам в специально устроенном павильоне в конце парка.

Кроме традиционного траурного цвета некрашеной ткани 素 sù в современном Китае стали использовать черный цвет. Траур по ушедшему соблюдают редко, в основном это можно увидеть фрагментарно, например, в виде небрежно приколотого к рукаву одежды куска необработанной ткани черного цвета. Суть скорее в безыскусности и простоте, исходящей от чувства утраты. Из добрых традиций прошлого сохраняется ровное отношение пожилых к предстоящим метаморфозам и как следствие, умиротворенное посещение «магазинов долголе- 
тия»寿衣店 shòuȳidiànc целью приобретения «одежды долголетия» и получения подарочных гробов в виде почтительного подарка от детей.

Если в традиции поклонения культу предков явно прослеживается сакральный характер происходящего, подразумевающий необходимость соблюдения процедуры ради общественного и семейного блага, репрезентации индивидуального и коллективного сценария поведения, то в отправлении других ритуалов, например, связанных с культом Земли, просматривается больший символизм, известная степень санкционированности обществом начала нового сельскохозяйственного сезона - процедура приобретает вид церемониального театрального действа, когда актер в одежде императора прокладывает первую борозду на пахоте. Это ежегодное событие не так чувствительно для китайцев в повседневной жизни, хотя каждый из них с гордостью заявляет о принадлежности к земледельческой нации.

Принимая во внимание основное отличие обрядов как высшей степени ритуализации, от обычаев, регламентирующих повседневную жизнь, необходимо обратить внимание на весьма заметный факт: от осуществления обрядов зависит жизнь коллектива, а несоблюдение обычаев индивидом может рассматриваться как нарушение норм, но возможные последствия никак не отражаются на жизни общества в целом.

Рассмотрим, к примеру, китайскую традицию, связанную с деторождением и функционированием женского организма в период репродуктивного возраста. В данном случае мы принимаем устоявшееся понимание традиции как длительного, преемственного от поколения к поколению события, которое способно регулировать менее важные, чем ритуал, обряд и церемониал фрагменты жизни. Регулирование происходит с помощью обычаев, имеющих по сравнению с традицией кратковременный характер и принимающих вид формы поведения, связанных с практической деятельностью. В быту человек стремится обеспечить свой биологический и социальный статус, удовлетворить материальные нужды и возникающие на уровне повседневности запросы, в то время как ритуал характеризуется стремлением к реализации духовных потребностей. 
Испокон веков женщина, находящаяся в положении, прерывающая беременность искусственно или будучи родильницей, должна была чутко следить за состоянием взаимодействия энергий, текущих по ее энергетическим каналам 经络 jīngluò. Опытные доктора традиционной китайской медицины способны определить даже пол будущего ребенка по пульсу матери. Сексуальная жизнь в силу обстоятельств запрещалась, кроме того, китаянке предстояло устранить материально понимаемую нечистоту, возникшую вследствие естественных причин, освободиться от духовного напряжения и зла и перейти в новое физиологическое состояние. Вероятно, с этим связан обычай «соблюдения месяца» со дня рождения ребенка или прерывания беременности. Этот термин записывается глагольной морфемой 坐 zuò (букв. «сидеть») 月子 уиѐzі (месяц). Налицо посылка к неактивному состоянию, что подтверждается и полученными сведениями, касающимися регламентирующей установки для женщины. Традиция предписывала женщине не вставать с постели, не совершать омовений, не утруждать себя домашними делами, не заниматься с малышом. Питание было насыщенным, с преобладанием протеина, обилием жидкости. С нашей точки зрения, условие соблюдения покоя и постельного режима связано с желанием избежать переохлаждения, учитывая, в каких бытовых условиях жили китайцы до недавнего времени, вполне понятно, что женщина могла легко приобрести такое заболевание, как артроз, возникающий в том числе, вследствие усиления стихии ветра и воды в организме. Рацион также составлен с учетом восполнения недостающего белка. Ребенком занимались все женщины семьи, которые могли поселиться в доме родильницы на целый месяц, дабы помочь осуществить «соблюдение месяца» по правилам.

Новации в описываемом обычае подразумевают более активное поведение женщины: разрешается вставать, менять одежду, заниматься с малышом. Принимать водные процедуры по-прежнему возбраняется, даже волосы не прибирают. Очевидно, что баланс стихий ветра и воды в организме легко нарушить, несмотря на приемлемые в 
большинстве случаев условия проживания. Меню расширено незначительно за счет жидкой пшенной каши, взваров и яиц (чаще всего утиных). Женская половина семьи может находиться в доме у родильницы постоянно, хотя для ухода за женщиной и ребенком нанимают специальную сиделку, называемую 月嫂 уиѐsăо, (букв. «золовка на месяц»), что при известной семейственности китайцев, переносимой на социальный уровень, вполне уместно. В некоторых случаях с первых дней жизни начинают осуществлять телесные практики применительно к младенцу: укладывание без подушки с целью формирования пока еще мягких костей черепа: плоский затылок считается красивым.

На 30-й и 29-й день после рождения мальчика и девочки соответственно, положено приглашать родственников на угощение, носящее название «вино на полную первую луну» 吃满月酒 chīmănyuèjiŭ; следующее празднование называется 百天 báitiān и отмечается в полные 100 дней со дня рождения ребенка. В старом Китае выбор имени осуществлялся после этого периода, у девочек личного имени могло и не быть, но было прозвище по системе родства 排 行 páiháng, например, 三妹 sānmèi, «третья сестренка». В годы строительства коммунизма обычай обращаться к специальному гадателю с просьбой выбрать имя для ребенка в точном соответствии с геомантическими представлениями не приветствовался, однако в последние годы китайцы прибегают к их услугам, стоимость составляет от 150 юаней и выше. Современные геоманты используют метод компьютерного подсчета состояния стихий на момент рождения малыша, что, несомненно, привносит нотку новаторства. Традиционно положено менять имя на менее звучное, если ребенок часто болеет, так как болезнь может «не узнать» малыша под новым именем. В последнее время ханьское население избегает использовать морфему 月 уuѐ «полная луна» в женских именах, подоплека такова, что полнота может реализоваться в теле.

На протяжении жизни человек находится под влиянием энергий 阴 yīn и 阳 yáng, от баланса которых собственно зависит его физиче- 
ское состояние. Человек рождается слабым (преобладание инь), затем энергия ян в нем усиливается, происходит взросление и возмужание, на склоне лет инь снова берет свое. Энергии материализуются в человеческом теле: все твердое есть средоточие ян, мягкое - инь. Болезнь наступает вследствие дисбаланса энергий и застоя цүи в энергетических каналах. Иногда резкое ухудшение здоровья и внезапная болезнь трактуется китайцами как «заболевание вследствие стресса», что по-китайски звучит как 上火 shànghuŏ, «погрузиться в стихию огня». Если заболевает член семьи, все родственники консолидируются, так как обычай предписывает проявление неусыпной заботы 体贴 tĭtiē, проявляющейся в обеспечении лекарствами западной и китайской медицины, коллективного сопровождения на прием к врачу (включая нахождение в его кабинете во время приема), круглосуточное присутствие в палате больного, обильное кормление продуктами, энергетически соответствующими излечению заболевания. 体贴 tĭtiē (в облегченном варианте) также положено проявлять в томслучае, если болеет близкий человек или коллега. Проявление заботы к немощному в принципе является нормой для любой культуры, но в китайской традиции она носит характер облигаторности, навязчивости и нарочитой обеспокоенности.

Впрочем, обычай неусыпной заботы можно пронаблюдать во многих бытовых ситуациях, прямо или косвенно связанных с телесностью. Например, в уходе за стариками, положено проявлять 养老 yănglăo, буквально «пестование старости». Древние медицинские трактаты содержат целые главы о том, как заботиться о пожилых, но нет ни слова об уходе за младенцами [31]. Пожилому человеку следовало меньше двигаться, есть, пить, говорить, даже смотреть. Это связано с идеей об известной конечности животворной энергии 气 qі̀: старику даже одежду не следовало покупать новую, так как прежняя напитана драгоценной 气 qì. Множество конфуцианских притч содержат упоминания о примерах крайней жертвенности, связанной с почтением к родителям. Известны случаи умерщвления новорожденного с целью избавиться от лишнего рта и прокормить старшее поко- 
ление семьи [2]. В современном Китае вектор направления заботы постепенно смещается на младшее поколение, если еще 20 лет назад дни рождения праздновали только людям в высоком возрасте, то теперь детские дни рождения отмечают с размахом. Старшее поколение тоже включено в систему неусыпной заботы - старики не только стараются экономить и накапливать сбережения для среднего поколения китайской семьи, но и провожают внуков в школу и из школы, беспокоятся о том, чтобы при себе у них была питьевая вода и тп. Согласно традиции, пожилые родители должны жить в доме младшего сына или дочери, со временем их место пребывания стало возможным либо в своем доме, либо у того из отпрысков, чье благосостояние выше остальных. По факту в последние несколько лет одиноких или нуждающихся в особом уходе отправляют в дома престарелых. В государственных заведениях стоимость пребывания оставляет от 1500 юаней в месяц, в частных содержание дороже - до 6000 юаней. Наблюдение достаточно строгое, хотя некоторые клиенты вполне мобильны, так в июле 2018 г в сети был упомянут забавный случай о двух постояльцах дома престарелых, которые самостоятельно покинули его и отправились на рок-фестиваль в соседний город 67].

Старшее поколение семьи проявляет неустанную заботу об устройстве брака сына или дочери. Территориально наблюдаются различия в подходе решения этой проблемы: на северо-востоке Китая чаще прибегают к услугам свах, которые устраивают смотрины 相亲 xiāngqīn, в юго-восточных районах родители лично посещают ярмарки женихов и невест. Эти мероприятия не лишены самобытного колорита, чаще напоминают уличный стихийный рынок, на котором претенденты выкладывают фотографии потенциальных супругов с подробным указанием материального положения, уровня образования, не обходится и без привычного китайскому глазу набор характеристик по фэншуй (год, месяц и дата рождения по лунному календарю, дабы стихии, присутствующие в гороскопе каждого из супругов не мешали гармонии в браке). В Шанхае такой рынок находится близ станции метро «Народная площадь», и в первую половину дня в выходные дни здесь множество стариков, которые подыскивают пару 
своему чаду. Можно разместить брачное объявление на стенде, плата взимается по тарифу, от 25 юаней в месяц. Традиция предписывает делать свадебные подарки и выкуп, новаторство возникает в ритуале брачного ухаживания, когда молодой человек должен для вступления в помолвку приобрести квартиру для совместного проживания, оформив ее на имя невесты, ее родители делают ремонт для молодых. Мужчина также должен проявлять неустанную заботу в период ухаживания (делать подарки, носить на спине, если девушка устала от прогулки в парке, делать легкий массаж спины); после свадьбы ко всем этим обязанностям добавляется готовка, уборка и стирка. Как считают китайцы, все это лучше получается у мужчин, женщина заботится и пестует свою красоту и выполняет репродуктивную функцию.

Забота старшего поколения распространяется на все сферы жизни, в том числе, если в результате болезни или несчастного случая безвременно уходит из жизни незамужняя девушка или неженатый молодой человек. Родителям необходимо провести ритуал посмертного брака, для которого выбирают недавно умершую девушку, так как осуществление такой процедуры с пожилыми дамами невыгодно семье - невестку надо содержать. В газетах появляются публикации о случаях незаконной эксгумации женских трупов с целью их продажи, либо об убийстве молодой женщины с той же самой целью. Согласно сообщениям, такие случаи происходят в юго-восточных регионах Китая, и в Гонконге. Так китайцы видят выполнение главной функции родителей - проявление заботы как о ребенке как о члене семьи, так и благополучии рода в целом. С точки зрения культурной релевантности такая форма символического поведения вполне оправдана, хотя, безусловно, и на уровне китайской повседневности воспринимается не всеми как абсолютная норма [17].

Таким образом, практически во всех формах символического поведения в современном китайском обществе наблюдается несущественные новации, которые можно рассматривать как рефлексию на глобальную культуру и ускорение темпа жизни обычного человека. Bсе рассмотренные нами примеры свидетельствуют о том, что в принципе функционирования этих форм лежит сформулированное 
Э.Эриксономпонимание «общего значения происходящего всеми участниками, при сохранении различий между индивидами; способность к развитию по стадиям жизненного цикла, в ходе которого достижения предыдущих стадий в дальнейшем приобретают символическое значение, а также взаимодействие людей, которые возобновляют его через определенные промежутки времени, сохраняя известную новизну и игровой характер» [47]. На уровне повседневности бо̀льшуюоблигаторность приобретают те обычаи, соблюдение которых направлено на коммуникацию внутри семьи, клана с целью усиления родственных связей, подвергающихся риску ослабления в силу академической, социальной и производственной мобильности современных китайцев. 


\section{Заключение}

Изучение личности в китайской культуре интересно с точки зрения следования принятой модели поведения в условиях социального окружения, так как оно определяет рамки нормы, способствует возникновению активного мышления и восприятия действительности, а также помогает индивидууму определить свое место в социуме. Процессы глобализации на современном этапе оказывают заметное влияние на трансформацию и репрезентацию этнического и национального самосознания, в данном контексте рассматриваемое как условный набор взаимозависимых переменных, которые могут быть «переупакованы» в целях конструирования национальной идентичности. Важными рычагами конструирования идентичностей попрежнему являются учебники, карты, СМИ, система образования и воспитания и т.п. Особыми приметами времени становятся ускорение процессов этнического и национального самоопределения, а также факт деятельного участия в этом процессе семьи как социальной ячейки. В этом случае формирование модальной личности происходит посредством непрерывного воспитательного процесса, воспринимаемого ребенком естественно и с большой степенью доверия. Исследование материала показало, что этнические китайцы склонны сохранять приверженность к традиционной матрице воспитания, делая упор на базовые представления об идеальной личности. Во главу угла ставится прагматический подход адаптации ребенка и включению его в общество. Для этого необходимо выработать стойкие навыки обучения в духе китайской педагогической методики, а содержание обучения существенно обогатить за счет прироста знаний, требуемых в глобализированном сообществе.

Модальная личность в китайском и тайваньском обществе обладает схожими конфуцианскими характеристиками, одинаково воспринимаемыми положительно на уровне этнической принадлежности во всем Большом Китае. Специфика модальной личности в континентальном и островном Китае проявляется тогда, когда возникает необходимость определения национальной идентичности. 
Процесс модернизации, начавшийся с поражения китайцев в Опиумных войнах более 170 лет назад, замедлялся или прерывался ввиду особенностей реализации внутренней политики КНР в прошлом, но, тем не менее, современный Китай представляет собой часть глобализированного сообщества, динамично развивающегося по законам мировой экономики и рынка, с учетом специфики китайского национального самосознания и внутренних условий. Статус женщины в китайском обществе также претерпел изменения, которые обусловлены экономическим, внутриполитическим и социальными факторами развития. На уровне повседневности академическая и социальная мобильность женщины по-прежнему решается сообща и с учетом семейных сугубо практических интересов, что вполне в духе традиционной культуры: китайцы никогда не задавались вопросом, что есть человек и откуда он взялся, но всегда интересовал вопрос, как его использовать.

Интенсивные внешние контакты, открытость Китая миру в последние десятилетия, а также некоторые другие факторы влияют на возникновение нового типа так называемого «модернизированного» китайца, который сочетает в себе некоторые традиционные черты с теми качествами, которые не были привиты китайской культурой способность к конкурентоспособности, ложная скромность, лицемерие и т.д.

Так возникает острая необходимость создать культурный противовес, для этого активно используются приемы создания современных мифов, героями которых становятся народные герои времени Большого Скачка, не совершавшие великих подвигов, но нашедшие свое место в анналах китайской истории, как и ценилось всегда, за неуклонное следование конфуцианским добродетелям, главные их которых - сыновняя почтительность и бескорыстное служение народу. Нравственный идеал современной личности, воспитанной в духе конфуцианских традиций, способен успешно адаптироваться к современным экономическим и политическим условиям страны. Эта личность, с одной стороны, занимает активную жизненную позицию в обществе, с другой, социально мобильна и демонстрирует успешность в разных сферах. 
Воспитание высокоморальной личности является одним из главных условий сохранения традиционных устоев общества. И в континентальном Китае, и на Тайване наблюдаются процессы модернизации личности под воздействием сразу нескольких факторов, каковыми, по нашему мнению, являются: глобализационные процессы, вестернизация, влияние господствующей идеологии (КПК, ГМД, ДПП).

Возникновение типа «модернизированного» китайца вполне объяснимо и с точки зрения того, что социальная жизнь индивида очень насыщена, а стремление к повышению уровня жизни способствует появлению качеств, которые не были присущи традиционному китайцу.В современном китайском социуме идеологически грамотно организован процесс воспитания, а упомянутый нами тип личности оказывается гармонично вписанным в рамки китайской повседневности.

Тип «модернизированного китайца» представляется нам динамичным (высокий ритм жизни в условиях глобализации), конкурентноспособным (большая популяция), готовым приспособиться к новым условиям (своего рода способность к выживанию в постиндустриальную эпоху). Конфуцианство является конструирующим элементом отношений внутри китайского социума на всех уровнях и оно, собственно, регулирует эти отношения. С поправкой на современность по-прежнему актуальны такие категории, как долг, ритуал, понятие чести и потери лица, благодетели и порока. Однако самыми жизнеспособными, на наш взгляд, оказались категории сыновней почтительности и преданности (Родине).

Они, как наиболее продуктивные и прагматичные, широко применимы во всей воспитательной системе Китая, начиная от малой ячейки общества семьи (家 jiā), и восходящей до государственности (国家 guójiā). Учитывая практичный характер современных китайцев, а также те объективные проблемы, с которыми они сталкиваются - перенаселение, старение населения, необходимость обеспечить занятость народных масс, очевидное расслоение населения, легко сконструировать те ситуации и вызовы, с которыми сталкиваются китайцы. 
Если русский человек живет верой в свою духовную миссию спасения себя и мира, а чаще верой в то, что все будет хорошо, то китаец существует с верой, что все так, как должно быть, и все делается так, как делали прославленные правители китайской древности. Отсюда и приемы воспитания, которые легко приложимы не только к китайскому обществу, но и к азиатским сообществам вообще. Особый склад мышления, покорность старшему, уверенность в правильность постулатов, знание того, что когда-то и он займет место старшего (по положению или в результате естественных процессов старения), включает человека в общество, где он занимает определенную нишу и создает ощущение гармонии, которое и обеспечивает категория сыновней почтительности.

Понятие верности или преданности Родине у китайцев сопряжено со сложными подсознательными процессами, передающимися с молоком матери. Мы имеем в виду соположение себя со священной ойкуменой, и любое перемещение от центра воспринимается негативно даже современными людьми. Так русский человек, подсознательно мыслящий в категориях «дом - свой», «лес - чужой» считает, что «дома и стены помогают», в то время как китаец размышляет более глобально, так как только в Китае «особые природные и иные условия» (中国地利真特殊 Zhōngguó dìlì zhēn tèshū). Поэтому среди китайцев мало тех, кого можно назвать предателями Родины, хотя такое выражение в китайском языке существует (卖国贼 màiguó zéi). Китайские эмигранты считаются «странствующими китайцами» и те, кто уезжает на постоянное место жительства, называются 华侨 huáqiáo «переселенцем китайской культуры».

Столкнувшись с тем, что нынешнее поколение китайской молодежи выросло излишне прагматичным даже с точки зрения самих китайцев, правящие круги приняли курс на популяризацию идеалов бескорыстного служения народу, взяв за образец для подражания жизнь героев социалистического строительства времен Большого экономического скачка.

Герои Культурной революции на данном историческом этапе не могут быть эпизированы, так как события тех лет воспринимаются 
разными поколениями по-разному, и эта тема слишком чувствительна и волнительна для народных масс. Возникают народные идолы, такие как Су Нин или Лэй Фэн. Они более притягательны, чем такие недоступные идеалы древности. Это узнаваемые типажи, простые парни, не совершившие никаких великих подвигов, но служившие бескорыстно своему обществу, состоящему из таких разных людей, сплоченных поклонению прекрасным благодетелям, общей идеей единения и принципами кровного родства. 


\section{Список литературы}

\section{Источник на китайском языке}

1. 美德书:中华传统美德格言 800 条/魏普风,唐继军编著. - 北 京中国华侨出版社, 2006.1. -318 页。Мэйдэшу: чжунхуа чуаньтун мэйдэ гэянь 800 тяо. - Бэйцзин Чжунго хуацяо чубаньшэ, 2006.1. 318 е. Книга облагодетели. 800 крылатых фраз о воспитании в высоком духе китайской традиции. - Пекин: Изд-во «Чжунго хуацяо», 2006.1. - 318c.

\section{Литература на русском языке}

2. Бамбуковые страницы. Антология древнекитайской литературы. Перев. С древнекит. И.С. Лисевича. - М.: Издательская фирма «Восточная литература» РАН, 1994. - 415с.

3. Байбурин, А.К. Ритуал в традиционной культуре. Структур.семант. Анализ восточнославянских обрядов / А.К. Байбурин. - СПб.: Наука, 1993. - 240c.

4. Баранов И.Г. Верования и обычаи китайцев. М.: ИД «Муравей-Гайд», 1999. -304c.

5. Буров В.Г. Китай и китайцы глазами российского ученого. М.: ИФ РАН, 2000. -208 с.

6. Васильев, Л.С. Культы, религии, традиции в Китае. 2-е изд. М.: Издательская фирма «Восточная литература» РАН, 2001. - 448c.

7. Всемирная энциклопедия философии / под. ред. А.А. Грицанова. -М.: АСТ, 2001. - 1312c.

8. Гао Лиэнн. Живое наследие// Тайваньская панорама, 2005. №2,C.48-56.

9. Гуревич, П.С. Первообразы культуры. Лики культуры. М.: Альманах, 1995. - 360.

10. Дай Муцай. В чем секрет успеха Китая на пути социализма/ Дай Муцай -Пекин: Межконтинентальное издательство Китая, 2016. $-261 \mathrm{c}$. 
11. Жизнь и нравы старого Китая / под ред. М.И. Рабиновича. - Смоленск: Русич, 2003. - 496с.

12. Завидовская, Е.А. Народная религия современного Тайваня. Храмовые организации и праздники / Е.А.Завидовская - СПб.: Наука, $2012,-174 \mathrm{c}$.

13. История японской культуры: учеб.пособие для вузов / отв. ред. А.Н.Мещеряков. - М.: Наталис, 2011. - 368 с.

14. Ишутина Ю.А. К вопросу о трансформации статуса женщины в китайском обществе в эпоху осуществленной модернизации//Вестник Кемеровского государственного университета культуры и искусств, 2018. № 45.

15. Ишутина Ю.А. О специфике воспитания в семьях этнических китайцев в КНР, на Тайване и в США//Вестник Кемеровского государственного университета культуры и искусств. 2018. № 45.

16. Ишутина Ю.А. О формировании и эволюции нравственного идеала в Китайской народной республике//Вестник Томского государственного университета. Культурология и искусствоведение.2017.№ 28.

17. Ишутина Ю.А. Традиции и новации в символических формах поведения китайцев//Ученые записки Комсомольского-на-Амуре государственного технического университета. Науки о человеке, обществе и культуре. 2018. № 4 (36).

18. Карапетьянц, А.М. У истоков китайской словесности: собрание трудов / А.М.Карапетьянц. - М.: Вост.лит., 2010. - 479c.

19. Кравцова, М.Е. История культуры Китая /М.Е.Кравцова. СПб.: Лань, 1999. - 631 с.

20. Крюков М.В., Софронов М.В., Чебоксаров Н.Н. Древние китайцы: проблемы этногенеза. М., 1978. - 342с.

21. М.В. Крюков, В.В.Малявин, М.В.Софронов. Этническая история китайцев на рубеже Средних веков. М., 1987. - 311 с.

22. Крюков, М.В., Малявин В.В., Софронов, М.В. Китайский этнос на пороге средних веков. М.: Наука, 1979. - 327с.

23. Малявин В.В. Гибель древней империи. М.: Наука, 1983. $223 \mathrm{c}$. 
24. Малявин В.В. Даосские каноны. Философская проза. Книга 2. Часть 1. «Чжуан-цзы». Внутренний раздел.- Иваново: Издательство «Роща», 2017. -384c.

25. Малявин, В.В. Китайская цивилизация. - М.: «Издательство Астрель», 2000. - 632 с.

26. Китайский этос или дар покоя. Иваново: Издательство «Роща», 2016. -384c.- 522 c.

27. Малявин, В.В. Сумерки дао. - М.: «Издательство Астрель», 2003. $-436 \mathrm{c}$.

28. Мартынов А.С. Государственное и этическое в императорском Китае // Этика и ритуал в традиционном Китае, 1988. C. $274-298$

29. Маслов, А.А. Китай: колокольца в пыли. Странствия мага и интеллектуала. - М.: Алетейа, 2003. - 376с.

30. Маслов, А.А. Китай: укрощение драконов. Духовные поиски и сакральный экстаз. - М.: Алетейа, 2003. - 480с.

31. Мещеряков, А.Н. История и культура традиционной Японии / А.Н. Мещеряков - М.: Наталис, 2014. - 520 с.

32. Печерица В.Ф., А.В. Бояркина Мягкая поступь желтого дракона: монография / В.Ф. Печерица, А.В.Бояркина. - Владивосток: ДВФУ, 2017. -164c.

33. Пу Сунлин. Рассказы Ляо Чжая о необычайном. М.: Художественная литература, 1988. - 558c.

34. Сидихменов В.Я. Китай: страницы прошлого. М.:Русич, 2010. -215 c.

35. Тань Аошуан. Китайская картина мира. - М.: Языки славянской культуры, 2004. - 240 с.

36. Спешнев Н.А. Дискуссия по этнопсихологии китайцев // Историко-культурный альманах Восток-Запад, М., 2005-2006.

37. Тертицкий К. Китайцы: традиционные ценности в современном мире: в 2 Т. М., 1994. - 347c.

38. Ткаченко, Г.А. Избранные труды. Китайская космология и антропология . - М.: ООО «РАО Говорящая книга», 2008. - 362c. 
39. Си Цзиньпин. О государственном управлении/ Си Цзиньпин. - Пекин: «Издательство литературы на иностранных языках», 2014.- 630c.

40. Харро фон Зенгер. 36 китайских стратагем. - М.: ЗАО «Олимп-бизнес», 2010.- 224c.

41. Цзинь Ли. Культурные основы обучения: Восток и Запад [Текст]/ Пер.с англ.А.Апполонова, Т.Котельниковой.-М.: Издательский дом высшей экономики, 2017.-464c.

42. Чжан Нин. Кизил краснеет в волосах//Китай. 2018 № 10 (156). C.74-75.

43. Чжао Юн. Кто боится большого злого дракона? Почему в Китае лучшая (и худшая) система образования в мире / Юн Чжао; пер. с англ. И. Полонской. - М.: Издательский дом Высшей школы экономики, 2017. - 302c.

44. Чэнь Цзявэй. Политический стиль тайваньского президента Чэнь Шуйбяня: символика и действительность (2000-2008) // Клио.2013. № 5 (77). С.115-119.

45. Чуа Эми. Боевой гимн матери-тигрицы / Эми Чуа; пер. с англ. Е.Щербаковой. - М.: ACT: CORPUS, 2013. -288c.

46. Шорт, Филип. Мао Цзэдун. - М.: ООО «Издательство $\mathrm{ACT} », 2001 .-608 \mathrm{c}$.

47. Эриксон, Э.Х. Идентичность: юность и кризис / Э.Х. Эриксон - М.: Флинта, 2006, - 342c.

48. Юань Кэ. Мифы Древнего Китая. Перев. С кит. Б.Л.Рифтина. - М.: Наука, 1987. -527c.

\section{Литература на китайском языке}

49. 百家姓。- 北京外语教学与研究出版社, 2010.8. - 125 页。 Бай цзя син. - Бэйцзин вайюй цзяосюэ юй яньцзю чубаньшэ, 2010.8. 125 е. Сто фамилий. - Пекин: Изд-во методической литературы иностранных языков, 2010.8. - 125с.

50. 王洋。永远的雷锋 //人民画报。2012. №3. - 34-50 页。Ван Ян. Юнъюаньдэ Лэй Фэн // Жэньминь хуабао. 2012. №3. - 34-50 е. Ван Ян // Лэй Фэн навсегда // Жэньминь хуабао. 2012.Вып.3. - С.34-50. 
51. 魏书生著。好父母好家庭: 魏书生谈家庭教育/魏书生著。一 桂林丽江出版社, 2017.5-246 页。Вэй Шушэн. Беседы о воспитании с Вэй Шушэном. Гуйлинь: Издательство «Лицзян», 2017, - 246с.

52. 千字文。- 北京外语教学与研究出版社, 2010.8. - 98 页。 Цянь цзы вэнь. - Бэйцзин вайюй цзяосюэ юй яньцзю чубаньшэ, 2010.8. - 98 е. Тысячесловие. - Пекин: Изд-во методической литературы иностранных языков, 2010.8. - 98c.

53. 李舒亚。本山心灵独白//人民画报。2012. №1. - 50- 56 页。 Ли Шуя. Бэньшань синьлин дубай // Жэньминь хуабао. 2012. №1. 50-56 е. Ли Шуя // Чжао Бэньшань: исповедь // Жэньминь хуабао. 2012.Вып.1. - C.50-56.

54. 李舒亚.。军工强国的新梦想/人民画报。2014. №3. - 58- 59 页。Ли Шуя. Цзюнь гун цян го дэ синь мэнсян // Жэньминь хуабао. 2014. №3. - 58-59 е. Ли Шуя // Новые мечты о сильном гоусдарстве// Жэньминь хуабао. 2014.Вып.3. - С.58-59.

55. 三字经。- 北京外语教学与研究出版社, 2010.8. - 104 页。 Сань цзы вэнь. - Бэйцзин вайюй цзяосюэ юй яньцзю чубаньшэ, 2010.8. -104 е. Троесловие. - Пекин: Изд-во методической литературы иностранных языков, 2010.8. - 104c.

56. 现代汉语词典。- 北京商务印书馆, 2002. - 1766 页。 Сяньдай ханьюй цыдянь. - Бэйцзин: Шанъу иньшугуань, 2002. - 1766 е. Словарь современного китайского языка. - Пекин: Изд-во коммерческой литературы, 2002. - $1766 \mathrm{c}$.

57. 唐诗三百首。一北京: 北京少年儿童出版社, 2007. - 255 页。 Тан ши сань бай шоу. - Бэйцзин: Бэйцзин шаонянь эртун чубаньшэ, 2007. - 255 е. Триста виршей танской поэзии. - Пекин: Изд-во детской и юношеской литературы, 2007. -255 c.

58. 陈录。姚明:不是告别// 人民画报。2011. № 8. - 10- 25 页。 Чэнь Мяо. Яо Мин: бу ши гаобе // Жэньминь хуабао. 2011. №8. - 1025 е. Чэнь Мяо // Яо Мин не прощается // Жэньминь хуабао. 2011. Вып. 8. - С.10-25. 
59. 品德。一长春:吉林出版社, 2010.9. - 72 页。Пинь дэ. - Чанчунь: Цзилинь чубаньшэ, 2010. - 72 е. Воспитание нравственности. Чанчунь: Изд-во провинции Цзилинь, 2010. $-72 \mathrm{c}$.

60. 孩奴/林铃著。上海文艺出版社。2010.5- 356 页。Линь Лин. Раба ребенка. Шанхай: Издательство «Искусство», 2015, - $256 \mathrm{c}$.

61. 蛙 / 莫言著。上海文艺出版. 2012.6 - 625 页。Мо Янь. Лягушка. Шанхай: Издательство «Искусство», 2015, - 625с.

62. 擦民情、听民声。习近平总书记胡同问政。2014. №3. -812 页。Ца миньцин.Тинминьшэн.// Жэньминь хуабао. 2014. №3. - 812 е. // Услышать глас народа, понять людские чаяния// Жэньминь хуабао. 2014.Вып.3. - С.8-12.

\section{Электронные ресурсы на русском языке}

63. Китай. Взаимоотношения (топик) [Электронный ресурс]: URL: http://polusharie.com/index.php?board=95.0 (дата обращения 06.08.2018).

64. Поговорим о Китае и китайцах (топик) [Электронный реcypc]: - URL: http://polusharie.com/index.php?topic=115449.msg734764 \#msg734764 (дата обращения 06.08.2018).

65. Помощь соотечественникам (топик). [Электронный ресурс]: - URL: http://polusharie.com/index.php?topic=178876.0 (дата обращения 06.08.2018).

\section{Электронные ресурсы на английском языке}

66. Attane, I. Being a Woman in China Today: A Demography of Gender [Electronic resource]: - URL: https://journals.openedit ion.org/chinaperspectives/6013?file=1 (датаобращения 06.08.2018).

67. А curious incident with retirement home. Режим доступа: https://www.thatsmags.com/shanghai

68. Haerbin hospital incident [Electronic resource]: - URL: https://www.bbc.com/zhongwen/simp/chinese_news/2012/07/120707_chin a_xi.shtml?c (датаобращения 06.12.2010). 
69. Shaanxi graduate told she is too short to be a teacher [Электронныйресурс]: - URL: http: // ThatsShanghai.com (датаобращения 06.08.2018).

\section{Электронные ресурсы на китайском языке}

70. 习近平。习近平谈治国理政。建设社会主义文化强国。提 高家文化软实力。Си Цзиньпин. О государственном управлении. Глава 6 «строительство могущественного социалистического культурного государства. Повысить национальную культурную мягкую силу».[Electronicresource]: http://sps.people.com.cn/xuexi/n/2015/0720/c397563-27331770.html

71. 中华人民共和国母婴保健法。Закон КНР о правах матери и ребенка [Electronicresource]: URL: http://www.npc.gov.cn/npc/ xinwen /2017-11/28/content_2032724.htm (дата обращения 06.08.2018).

72. 中华人民共和国婚姻法(1980 年)。Закон KHP о браке [Electronicresource] URL: http://www.lawlib.com/law/law_view.asp?id=44312(дата обращения 06.08.2018)

73. 中国文化革命图画。Китайские агитационные плакаты времен Культурной революции [Electronicresource] - URL: https:/photochronograph.ru/2016/07/17/propagandistskie-plakaty-kitaya/ 


\section{Приложение A}

1. Изображение иероглифа shàn в стиле сяочжуань

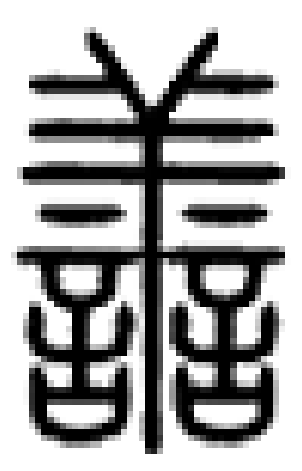

2. Изображение иероглифа уі̀ в полном варианте написания

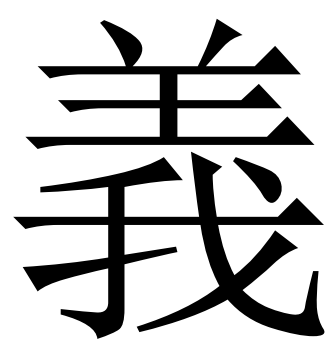

3. Изображение иероглифа хі́ в полном варианте написания

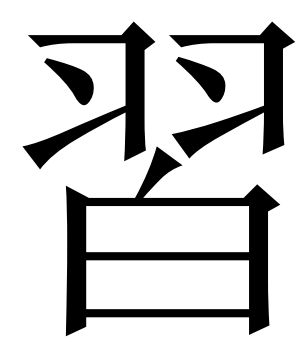




\section{Приложение Б}

\section{Китайский агитационный плакат}
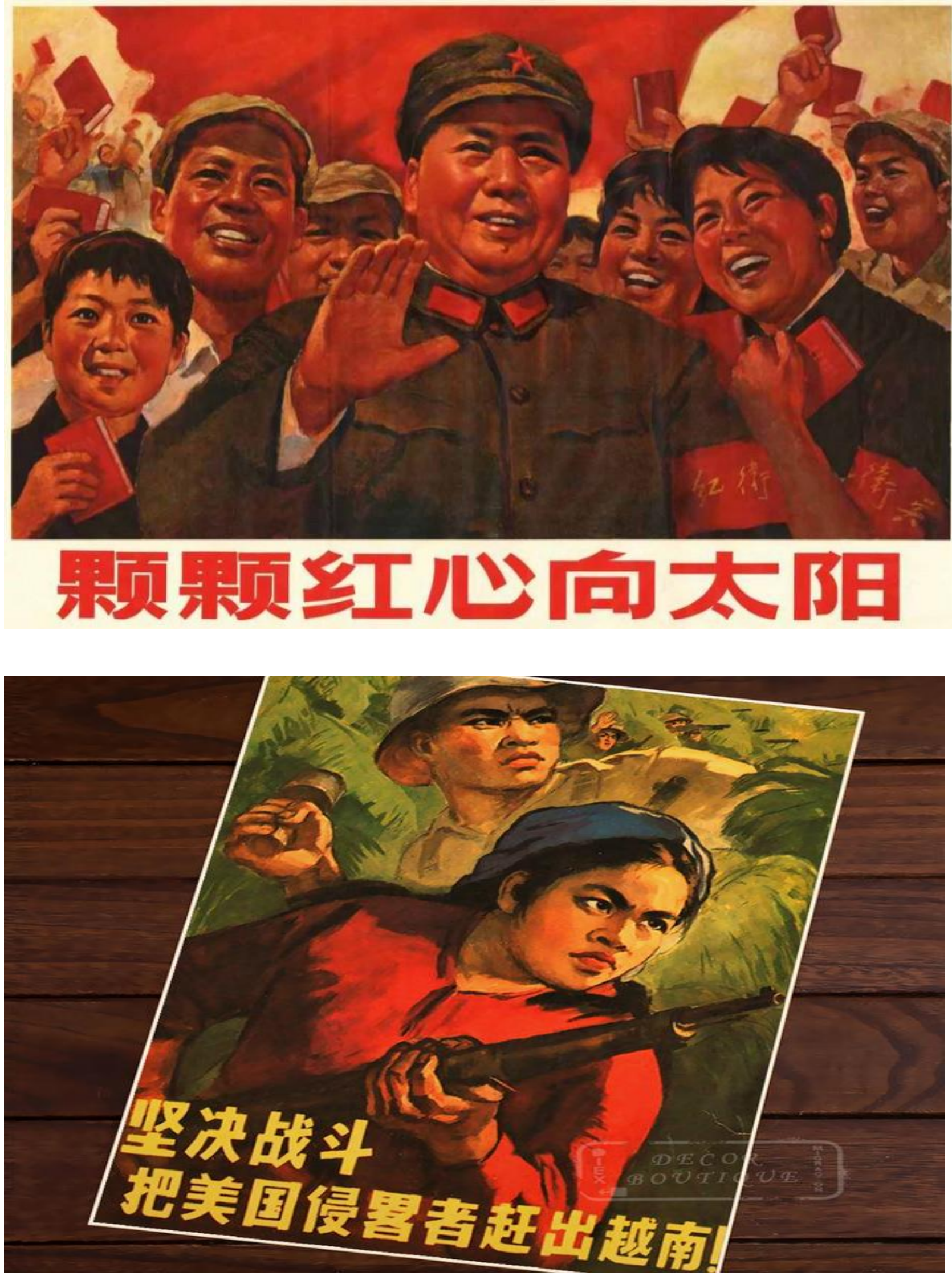

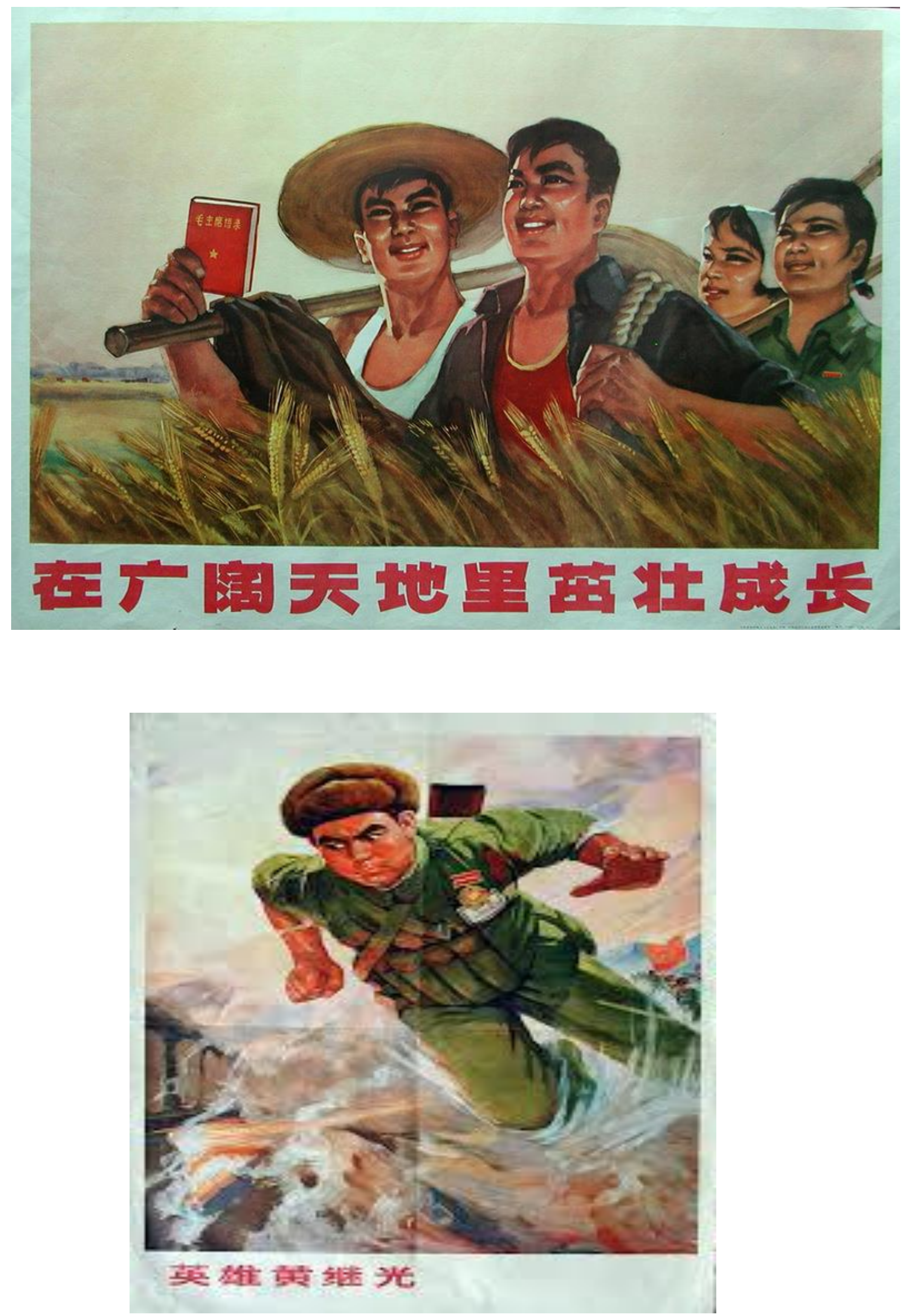


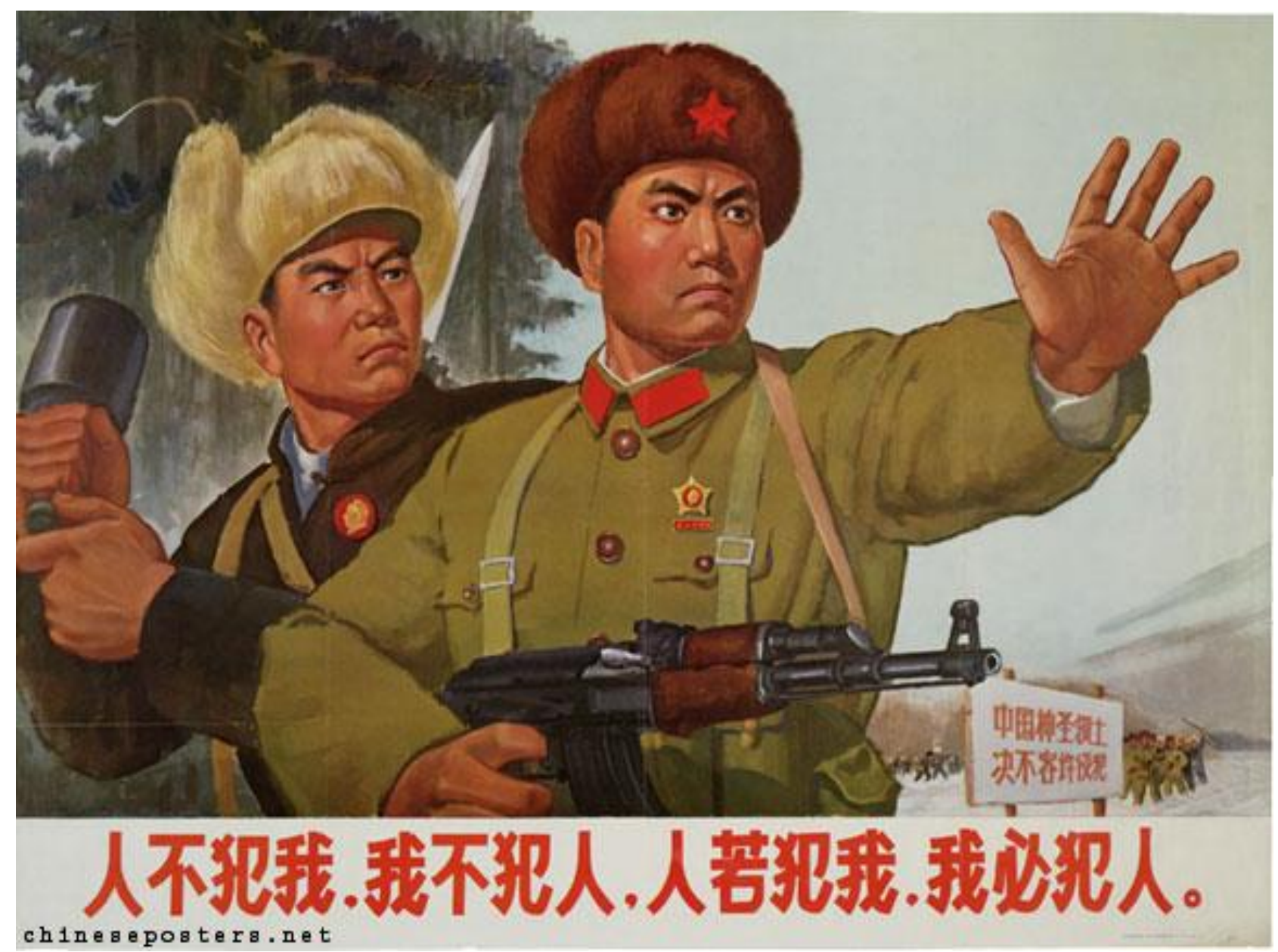




\section{Приложение В}

\section{Фотография народного героя \\ Лэй Фэна (Лэй Чжэнсина) (1940-1962 гг.)}
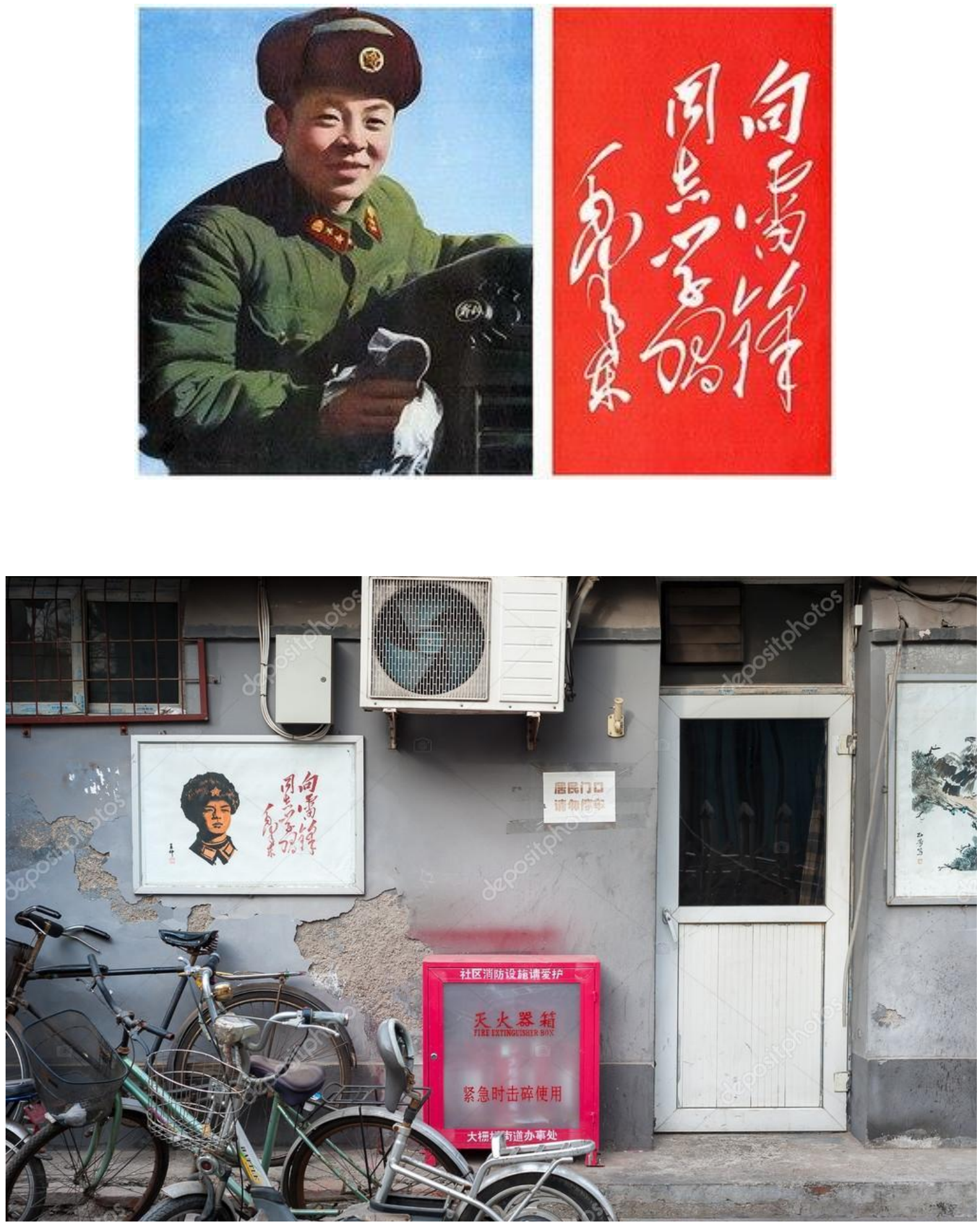


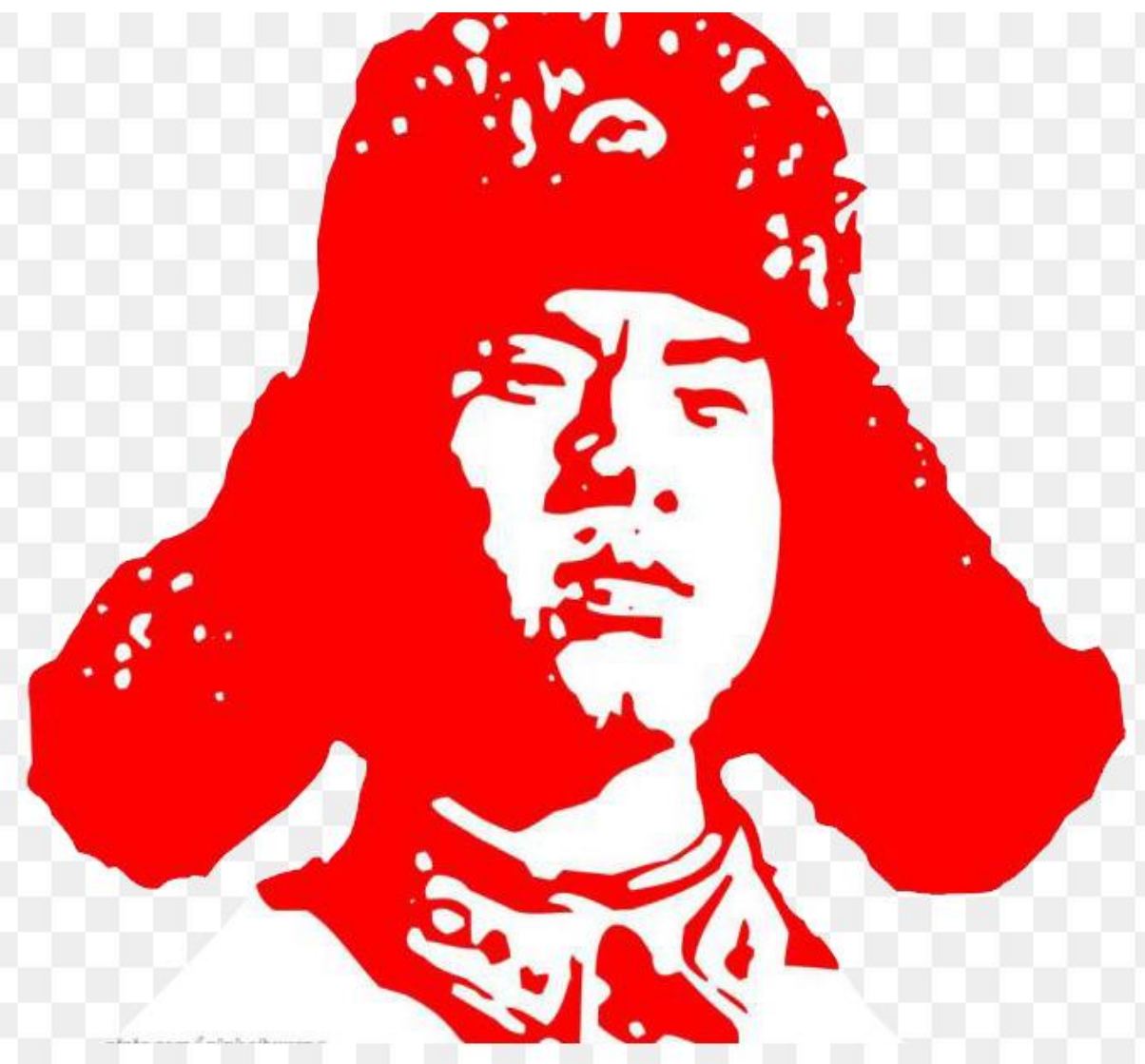


Научное издание

Ишутина Юлия Александровна

\section{Китайский опыт нравственного воспитания: восхождение к идеалу}

Монография 
Подписано в печать 05.11.2018 г.

Формат 60×84 / 16. Усл. печ. л. 6,39.

Тираж 500 экз. Заказ 549-А.

Дальневосточный федеральный университет 690091, г. Владивосток, ул. Суханова, 8

Отпечатано в Дальневосточном федеральном университете 690091, г. Владивосток, ул. Суханова, 8

(Типография Издательства ДВФУ, 690091, г. Владивосток, ул. Пушкинская, 10) 